Prepared in cooperation with Elko, Nevada

\title{
Properties of Basin-Fill Deposits, a 1971-2000 Water Budget, and Surface-Water-Groundwater Interactions in the Upper Humboldt River Basin, Northeastern Nevada
}

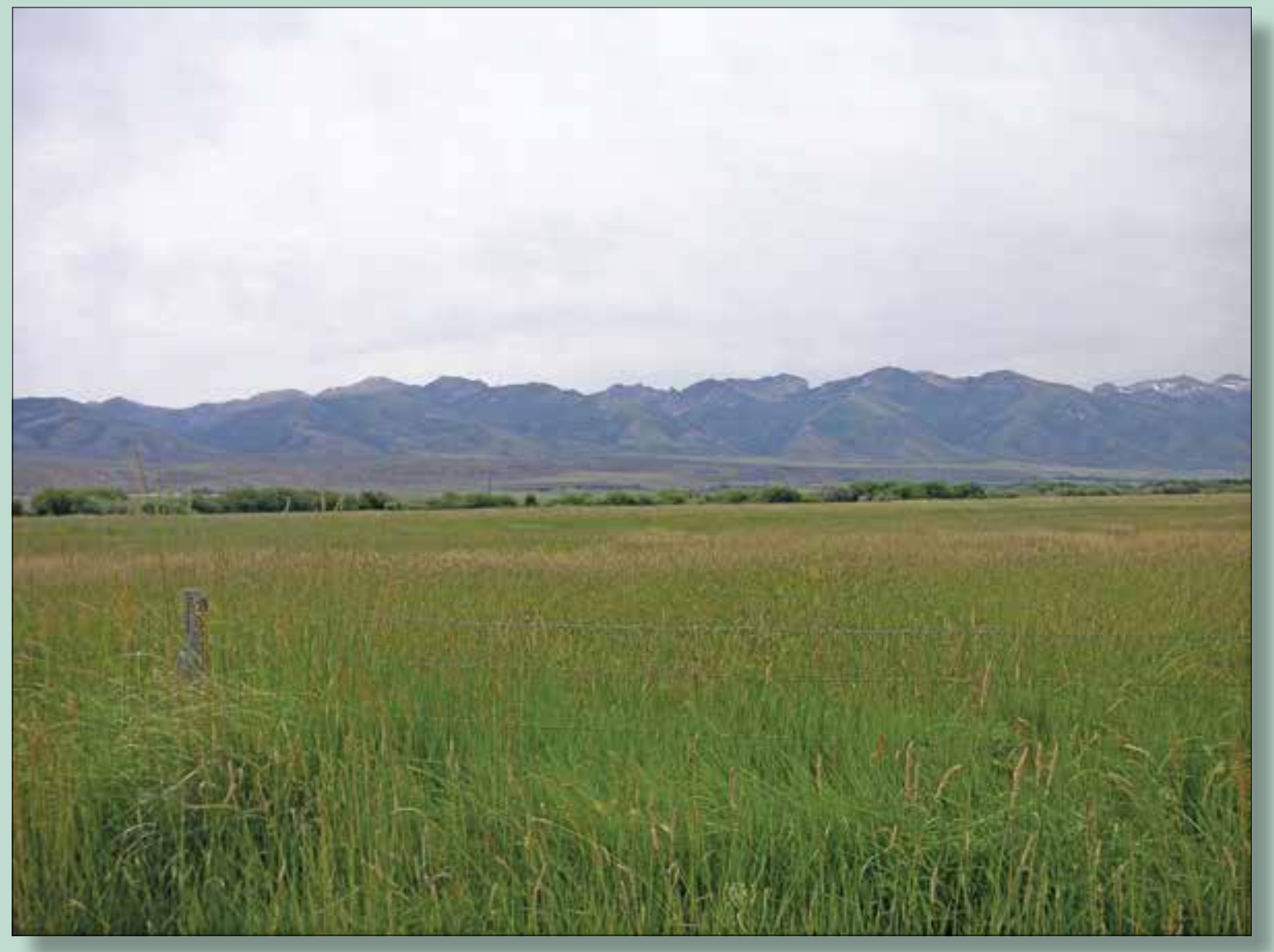

Scientific Investigations Report 2013-5077 
Cover image: Meadow in Lamoille Creek flood plain looking north from Lower Lamoille Road toward Peko Hills. Photograph by J.L. Smith, USGS, July 23, 2009. 


\section{Properties of Basin-Fill Deposits, a 1971-2000 Water Budget, and Surface- Water-Groundwater Interactions in the Upper Humboldt River Basin, Northeastern Nevada}

By Russell W. Plume and J. LaRue Smith

Prepared in cooperation with Elko County, Nevada

Scientific Investigations Report 2013-5077 


\section{U.S. Department of the Interior \\ KEN SALAZAR, Secretary \\ U.S. Geological Survey \\ Marcia K. McNutt, Director}

U.S. Geological Survey, Reston, Virginia: 2013

For more information on the USGS - the Federal source for science about the Earth, its natural and living resources, natural hazards, and the environment, visit http://Www.usgs.gov or call 1-888-ASK-USGS.

For an overview of USGS information products, including maps, imagery, and publications, visit $h t t p: / / w w w . u s g s . g o v / p u b p r o d$.

To order this and other USGS information products, visit http://store.usgs.gov.

Any use of trade, firm, or product names is for descriptive purposes only and does not imply endorsement by the U.S. Government.

Although this information product, for the most part, is in the public domain, it also may contain copyrighted materials as noted in the text. Permission to reproduce copyrighted items must be secured from the copyright owner.

Suggested citation:

Plume, R.W., and Smith, J.L., 2013, Properties of basin-fill deposits, a 1971-2000 water budget, and surface-watergroundwater interactions in the upper Humboldt River basin, northeastern Nevada: U.S. Geological Survey Scientific Investigations Report 2013-5077, 38 p., http://pubs. usgs.gov/sir/2013/5077/. 


\section{Contents}

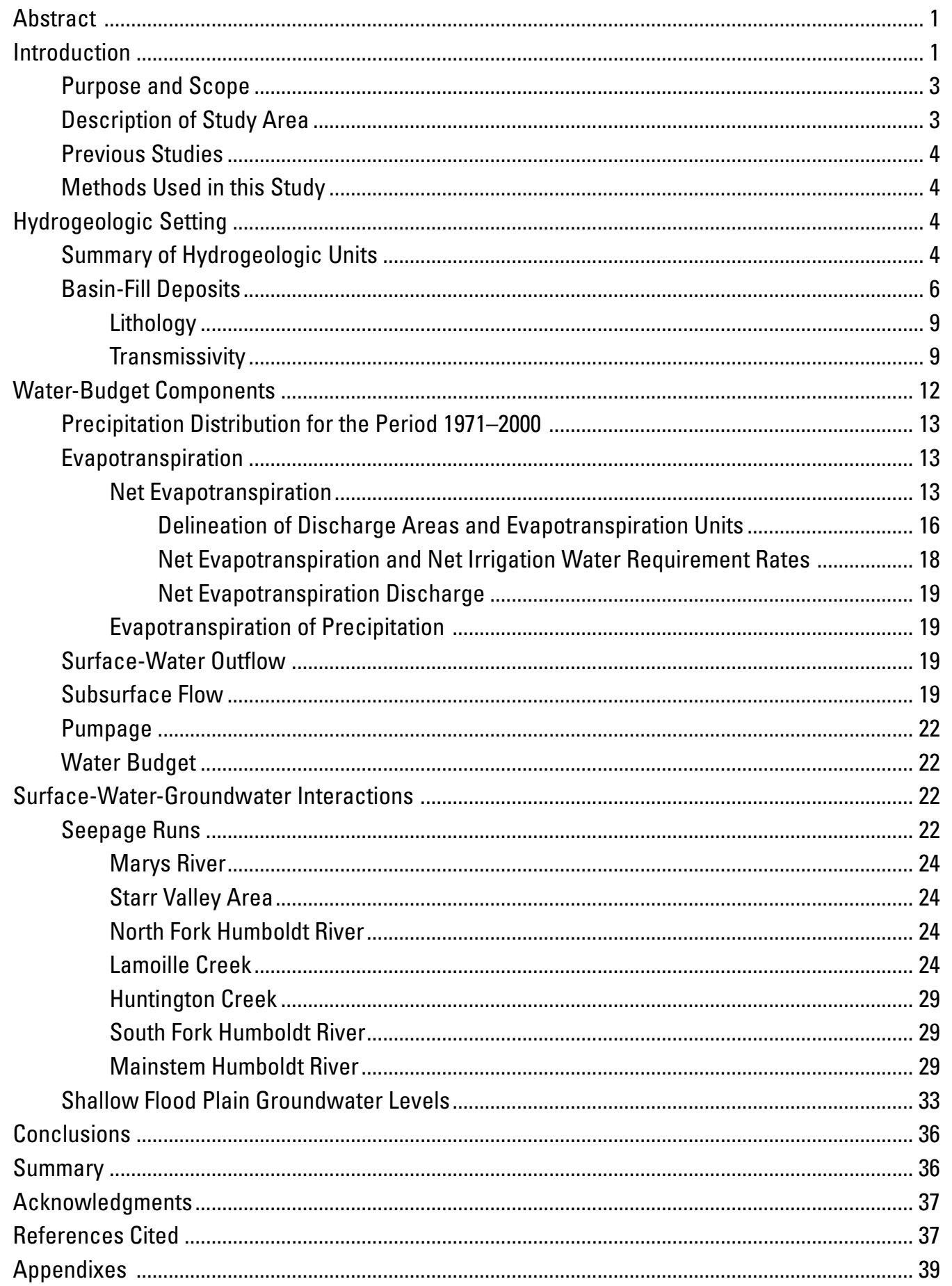




\section{Figures}

1. Map showing selected features of the upper Humboldt River basin, northeastern Nevada

2. Hydrogeologic map of the upper Humboldt River basin, northeastern Nevada

3. Map showing extent of Miocene Elko basin and Pliocene lake, upper Humboldt River basin, northeastern Nevada

4. Map showing extent of Miocene Elko basin, Pliocene lake, and percentages of finegrained sediments in upper 200 feet of basin fill, upper Humboldt River basin, northeastern Nevada

5. Map showing extent of Miocene Elko basin, Pliocene lake, and estimated transmissivity of basin-fill deposits, upper Humboldt River basin, northeastern Nevada .... 11

6. Map showing distribution of estimated annual precipitation, 1971-2000, upper Humboldt River basin, northeastern Nevada.

7. Map showing discharge areas and evapotranspiration units delineated July 20-24, 2009 in the upper Humboldt River basin, northeastern Nevada

8. Pie chart showing distribution of evapotranspiration by evapotranspiration unit, as a percentage of total discharge area, upper Humboldt River basin, northeastern Nevada.

9. Bar chart showing annual flow of the Humboldt River near Carlin, 1945-2010, northeastern Nevada

10. Map showing locations of subsurface flow sections, upper Humboldt River basin, northeastern Nevada

11. Graphs showing streamflow conditions at six gaging stations before and during the fall seepage runs in the upper Humboldt River basin, northeastern Nevada: $A, 0$ ctober 2008 and $B, 0$ ctober and early November 2009

12. Map showing locations of sites where streamflow was measured during fall seepage runs, 2008-09, upper Humboldt River basin, northeastern Nevada 25

13. Map showing $A$, locations of sites where streamflow was measured in the Marys River Area during the fall seepage runs of 2008 and 2009 and $B$, Streamflow measurements along Marys River between sites MR1 and MR5, upper Humboldt River basin, northeastern Nevada

14. Map showing $A$, Locations of sites where streamflow was measured in the North Fork Area during the fall seepage runs, 2008 and 2009, and $B$, Streamflow measurements along the North Fork Humboldt River between sites NF1 and NF7, upper Humboldt River basin, northeastern Nevada

15. Map showing $A$, Locations of sites where streamflow was measured in Lamoille Valley during the fall seepage runs, 2008 and 2009, and $B$, Streamflow measurements along Lamoille Creek and its diversions between sites LC1 and LC8, upper Humboldt River basin, northeastern Nevada.

16. Map showing $A$, Locations of sites where streamflow was measured in Huntington Valley during the fall seepage runs, 2008 and 2009, and (B) Streamflow measurements along Huntington Creek between sites $\mathrm{HC} 1$ and $\mathrm{HC}$, upper Humboldt River basin, northeastern Nevada

17. Map showing $A$, Locations of sites where streamflow was measured on the South Fork Humboldt River during the fall seepage runs, 2008-09, and $B$, Streamflow measurements along the South Fork Humboldt River between sites SF1 and SF12, upper Humboldt River basin, northeastern Nevada 
18. Map showing $A$, Locations of sites where streamflow was measured on the mainstem Humboldt River during the fall seepage runs, 2008 and 2009, and $B$, Streamflow measurements along the mainstem Humboldt River between sites HR1 and HR16, upper Humboldt River basin, northeastern Nevada

19. Map showing location of shallow wells MR-1, MR-2, MR-3 and MR-4 drilled in the Humboldt River flood plain below Elko, upper Humboldt River basin, northeastern Nevada 34

20. Graph showing stage of the Humboldt River and groundwater levels in the adjacent flood plain near Elko, upper Humboldt River basin, northeastern Nevada .... 36

\section{Tables}

1. Hydrographic areas of the upper Humboldt River basin, northeastern Nevada 3

2. Lithology, thickness, extent, and water-bearing characteristics of hydrogeologic units in the upper Humboldt River basin, northeastern Nevada.

3. Summary statistics for transmissivity of basin-fill aquifers in the upper Humboldt River basin, northeastern Nevada

4. Summary statistics for annual precipitation, 1971-2000, in hydrographic areas of the upper Humboldt River basin, northeastern Nevada 13

5. Evapotranspiration units delineated within discharge areas, upper Humboldt River basin, northeastern Nevada

6. Areas of evapotranspiration units and volumes of net evapotranspiration in discharge areas by hydrographic area in the upper Humboldt River basin, northeastern Nevada

7. Estimates of subsurface flow at eight aquifer cross sections in the upper Humboldt River basin, northeastern Nevada

8. Annual water budget, 1971-2000, for the upper Humboldt River basin, northeastern Nevada..

9. Lithology of Humboldt River flood plain deposits penetrated by wells MR-1, MR-2, MR-3, and MR-4 near Elko, upper Humboldt River basin, northeastern Nevada ......... 35

Appendix 1. Sites where streamflow was measured, October 2008 and November 2009, upper Humboldt River basin, northeastern Nevada

Appendix 2. Streamflow on the Humboldt River and its tributaries, October 20-24, 2008, upper Humboldt River basin, northeastern Nevada

Appendix 3. Streamflow on the Humboldt River and its tributaries, November 2-6, 2009, upper Humboldt River basin, northeastern Nevada 


\section{Conversion Factors and Datums}

Inch/Pound to SI

\begin{tabular}{|c|c|c|}
\hline Multiply & By & To obtain \\
\hline \multicolumn{3}{|c|}{ Length } \\
\hline inch (in) & 2.54 & centimeter $(\mathrm{cm})$ \\
\hline foot $(\mathrm{ft})$ & 0.3048 & meter $(\mathrm{m})$ \\
\hline mile (mi) & 1.609 & kilometer (km) \\
\hline \multicolumn{3}{|c|}{ Area } \\
\hline acre & 4,047 & square meter $\left(\mathrm{m}^{2}\right)$ \\
\hline square mile $\left(\mathrm{mi}^{2}\right)$ & 2.590 & square kilometer $\left(\mathrm{km}^{2}\right)$ \\
\hline \multicolumn{3}{|c|}{ Volume } \\
\hline acre-foot (acre-ft) & 1,233 & cubic meter $\left(\mathrm{m}^{3}\right)$ \\
\hline \multicolumn{3}{|c|}{ Flow rate } \\
\hline acre-foot per year (acre-ft/yr) & 1,233 & cubic meter per year $\left(\mathrm{m}^{3} / \mathrm{yr}\right)$ \\
\hline gallon per minute (gal/min) & 0.06309 & liter per second $(\mathrm{L} / \mathrm{s})$ \\
\hline cubic foot per second $\left(\mathrm{ft}^{3} / \mathrm{s}\right)$ & 0.02832 & cubic meter per second $\left(\mathrm{m}^{3} / \mathrm{s}\right)$ \\
\hline inch per year (in/yr) & 2.54 & centimeter per year (cm/yr) \\
\hline \multicolumn{3}{|c|}{ Specific capacity } \\
\hline $\begin{array}{l}\text { gallon per minute per foot } \\
[(\mathrm{gal} / \mathrm{min}) / \mathrm{ft})]\end{array}$ & 0.2070 & $\begin{array}{l}\text { liter per second per meter } \\
{[(\mathrm{L} / \mathrm{s}) / \mathrm{m}]}\end{array}$ \\
\hline \multicolumn{3}{|c|}{ Hydraulic gradient } \\
\hline foot per mile (ft/mi) & 0.1894 & meter per kilometer $(\mathrm{m} / \mathrm{km})$ \\
\hline \multicolumn{3}{|c|}{ Transmissivity* } \\
\hline foot squared per day $\left(\mathrm{ft}^{2} / \mathrm{d}\right)$ & 0.09290 & meter squared per day $\left(\mathrm{m}^{2} / \mathrm{d}\right)$ \\
\hline
\end{tabular}

Vertical coordinate information is referenced to the North American Vertical Datum of 1988 (NAVD 88).

Horizontal coordinate information is referenced to the North American Datum of 1983 (NAD 83).

Altitude, as used in this report, refers to distance above the vertical datum.

*Transmissivity: The standard unit for transmissivity is cubic foot per day per square foot times foot of aquifer thickness [(ft $\left.\left.\mathrm{ft}^{3} / \mathrm{d}\right) / \mathrm{ft}^{2}\right] \mathrm{ft}$. In this report, the mathematically reduced form, foot squared per day $\left(\mathrm{ft}^{2} / \mathrm{d}\right)$, is used for convenience. 


\title{
Abbreviations
}

\author{
ET evapotranspiration \\ GIS geographic information system \\ $\mathrm{Ma} \quad$ millions of years before present \\ MSAVI Modified-Soil Adjusted Vegetation Index \\ NAIP National Agricultural Imagery Program \\ NDWR Nevada Division of Water Resources \\ NIWR net irrigation water requirement \\ PRISM Parameter-Elevation Regressions on Independent Slopes Model \\ TM Thematic Mapper \\ USGS U.S. Geological Survey
}




\title{
Properties of Basin-Fill Deposits, a 1971-2000 Water Budget, and Surface-Water-Groundwater Interactions in the Upper Humboldt River Basin, Northeastern Nevada
}

\author{
By Russell W. Plume and J.L. Smith
}

\section{Abstract}

This study was done in cooperation with Elko County, Nevada in response to concerns over growing demand for water within the county and increasing external demands that are occurring statewide. The upper Humboldt River basin encompasses 4,360 square miles in northeastern Nevada and includes the headwaters area of the Humboldt River. Nearly all of the mean annual flow of the Humboldt River originates in this area. Basin-fill deposits function as the principal aquifers in the upper Humboldt River basin. Over much of the basin lowlands, the upper 200 feet of basin fill consists of clay, silt, sand, and gravel deposited in a lake of middle to late Pliocene age. Fine-grained lacustrine sediments compose from 30 to more than 70 percent of the deposits. Mean values of transmissivity are less than 1,000 feet squared per day. Total inflow to the upper Humboldt River basin, about 3,330,000 acre-feet per year, is entirely from annual precipitation. Total outflow from the basin, about 3,330,000 acre-feet per year, occurs as evapotranspiration, streamflow, subsurface flow, and pumpage. The uncertainty of these values of inflow and outflow is estimated to be 25 percent.

Baseflow of the Humboldt River is minimal upstream of the Elko Hills and in downstream reaches almost all baseflow comes from tributary inflow of the North Fork and South Fork Humboldt Rivers. However, the baseflow of these two tributaries comes from groundwater discharge to their respective channels in canyons incised in volcanic rocks along the North Fork and in carbonate rocks along the South Fork. Water levels in the shallow water-table aquifer along the Humboldt River flood plain fluctuate with changes in stage of the river. During high rising river stage in spring and early summer, streamflow enters the aquifer as bank storage. As stage begins to decline in early to mid-summer groundwater in bank storage begins discharging back into the river channel and this continues through late summer. In years of below average flow some reaches of the river are dry in late summer. Flood plain deposits are more permeable than adjacent and underlying fine-grained sediments of the Pliocene lake and the two aquifers are poorly connected.

\section{Introduction}

The Humboldt River basin is the largest river basin that is entirely within the State of Nevada. Numerous diversions reduce flow in the river ${ }^{1}$, and diverted surface water is used almost exclusively for irrigation, especially in the middle and lower reaches. Average annual flow of the river at the western side of the upper Humboldt River basin is about 270,000 acre-feet per year (acre-ft/yr; Maurer and others, 1996, p. 29). Downstream of here the river consistently loses flow and the only perennial tributary is Pine Creek with average annual flow of 9,600 acre-ft/yr (Maurer and others, 1996, p. 29). Even though the upper Humboldt River basin encompasses only about 25 percent of the entire river basin (fig. 1), the upper basin is the source more than 95 percent of the total flow of the river.

Elko County officials and citizens are concerned about the growing demand for water within the county and increasing external demands that are occurring statewide. Because flow of the Humboldt River and its tributaries is fully appropriated, any additional water needed to support growth in the upper Humboldt River basin presumably would come from groundwater. However, groundwater and streamflow are believed to be connected in parts of the study area where groundwater discharge to stream channels may sustain baseflow during periods of low flow. Decisions to further develop the groundwater resources within the upper Humboldt River basin will need to consider the potential effects of such development on streamflow. County and State water-resources managers need additional information that will enable them to make informed decisions regarding future use of the groundwater resources of the upper Humboldt River basin. To address these needs and concerns, the U.S. Geological Survey (USGS), in cooperation with Elko County, has adopted a phased approach for assessing the water resources of the upper Humboldt River basin in northeastern Nevada. Phase one was completed in 2007-08 and describes the hydrogeologic framework and groundwater conditions (Plume, 2009). Results of phase two, conducted

\footnotetext{
${ }^{1}$ The duration of the irrigation season in the upper Humboldt River basin each year is April 15-August 15 (Malone, 1932, p. 13).
} 


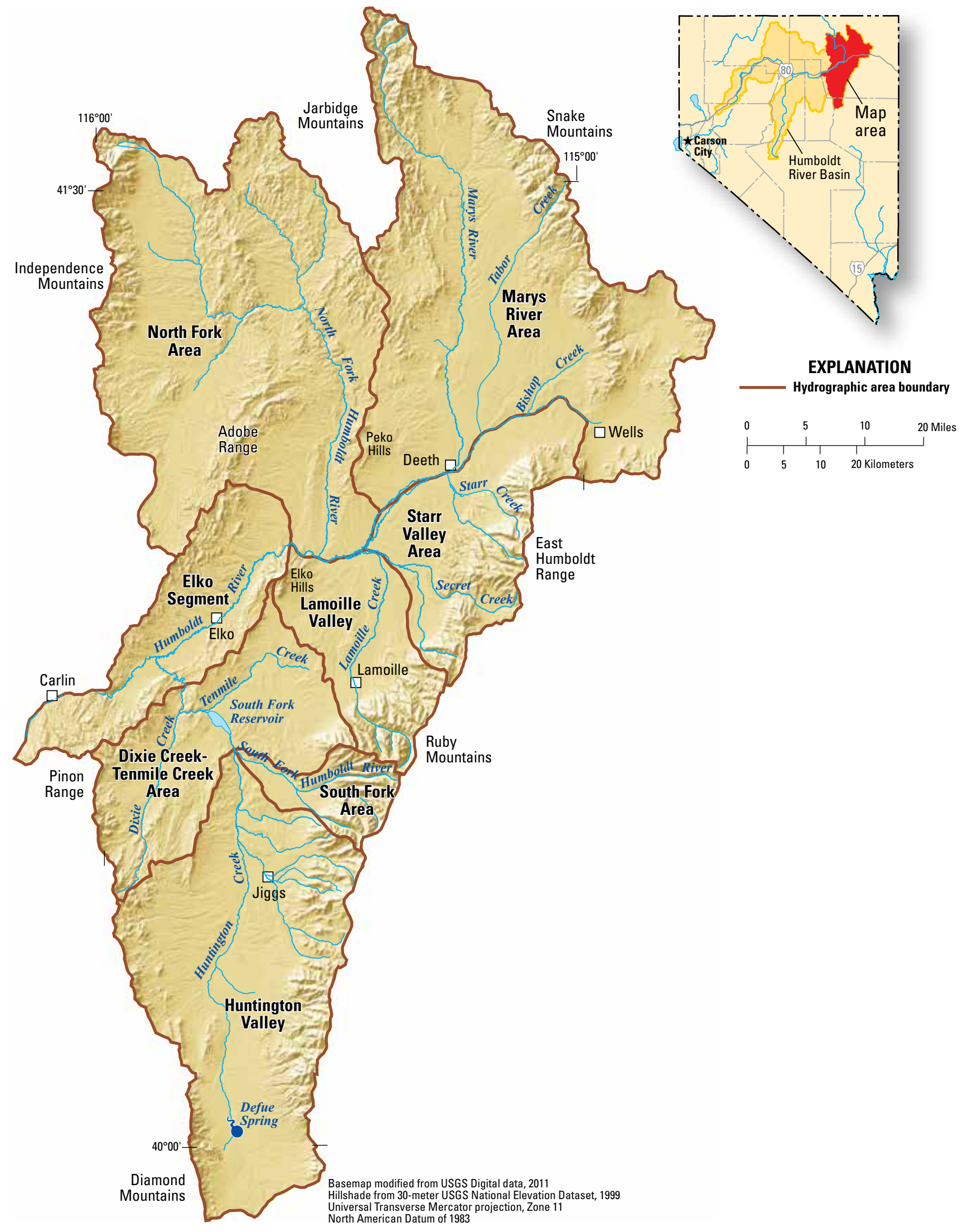

Figure 1. Selected features of the upper Humboldt River basin, northeastern Nevada. 
in federal fiscal years 2009-11, are presented in this report, which describes properties of basin-fill deposits, presents an overall water budget for the period 1971-2000, and describes interactions of groundwater and streamflow along the mainstem Humboldt River and its main tributaries.

\section{Purpose and Scope}

This report presents the results of phase two of the overall study - properties of basin-fill deposits, a refined annual water budget for the period 1971-2000, and characteristics of surface-water and groundwater interactions in the upper Humboldt River basin. Well drillers' logs, available from the Nevada Division of Water Resources (NDWR) website (http://water.nv.gov/data/welllog/) were used to determine hydraulic and lithologic properties of basin-fill aquifers. Components of the water budget were refined based on recent (1971-2000) estimates of annual precipitation, streamflow, evapotranspiration (ET) rates, estimates of subsurface outflow, and annual groundwater pumpage. The overall water budget for the upper Humboldt River basin integrates the eight hydrographic areas encompassing the basin. Interactions between surface water and groundwater were characterized by identifying locations of streamflow losses to infiltration and streamflow gains from groundwater seepage, and along a select reach of the river by comparing stage of the river with adjacent groundwater levels.

\section{Description of Study Area}

The upper Humboldt River basin covers about 4,360 square miles $\left(\mathrm{mi}^{2}\right)$ in northeastern Nevada, and consists of eight hydrographic areas-Marys River Area, Starr Valley Area, North Fork Area, Lamoille Valley, South Fork Area, Huntington Valley, Dixie Creek-Tenmile Creek Area, and the Elko Segment (fig. 1; table 1). The eight areas compose the headwaters of the Humboldt River, which is the source of more than 95 percent of the total flow of the river in years of average flow. From west to east, the main tributaries of the upper Humboldt River are South Fork Humboldt River, North Fork Humboldt River, Lamoille Creek, and Marys River (fig. 1). Other less significant tributaries include Secret, Starr, Tabor, and Bishop Creeks. Altitude of land surface in the study area ranges from 4,900 to 5,900 feet (ft) along the flood plain of the Humboldt River to greater than $11,000 \mathrm{ft}$ in the highest parts of the Ruby Mountains.

The Marys River Area covers 1,073 $\mathrm{mi}^{2}$ and is drained by Marys River and its tributaries on the north and west and by Bishop and Tabor Creeks on the east (fig. 1). The area is bounded by the Snake Mountains to the east, the Jarbidge Mountains to the north, the Peko Hills to the west, and by the Humboldt River to the south.

The Starr Valley Area covers $332 \mathrm{mi}^{2}$ and is drained by Starr and Secret Creeks and their tributaries (fig. 1). The area consists of a northwest sloping pediment bounded by the East Humboldt Range to the east and the Humboldt River to the northwest (fig. 1).
Table 1. Hydrographic areas of the upper Humboldt River basin, northeastern Nevada.

[See figure 1 for locations of hydrographic areas. Hydrographic area: Formal hydrographic areas in Nevada were delineated systematically by the U.S. Geological Survey and Nevada Division of Water Resources in the late 1960s (Cardinalli and others, 1968; and Rush, 1968). These areas have been the basic units for assembling hydrologic data and for regulating water use in the State since 1968. The official hydrographic area names, numbers, and geographic boundaries continue to be used in U.S. Geological Survey scientific reports and Nevada Division of Water Resources administrative activities. Area (square miles): From Rush (1968)]

\begin{tabular}{lccc}
\hline \multicolumn{1}{c}{ Name } & Number & $\begin{array}{c}\text { Area } \\
\text { (square miles) }\end{array}$ & $\begin{array}{c}\text { Area } \\
\text { (acres) }\end{array}$ \\
\hline Marys River & 42 & 1,073 & 686,720 \\
Starr Valley & 43 & 332 & 212,480 \\
North Fork & 44 & 1,110 & 710,400 \\
Lamoille Valley & 45 & 257 & 164,480 \\
South Fork & 46 & 99 & 63,360 \\
Huntington Valley & 47 & 787 & 503,680 \\
Dixie Creek-Tenmile Creek & 48 & 392 & 250,880 \\
Elko Segment & 49 & 314 & 200,960 \\
\hline Totals (rounded) & & $\mathbf{4 , 3 6 0}$ & $\mathbf{2 , 7 9 0 , 0 0 0}$ \\
\hline
\end{tabular}

The North Fork Area covers 1,110 $\mathrm{mi}^{2}$ and consists of an upper and lower basin both drained by the North Fork Humboldt River and its tributaries (fig. 1). The upper basin is bounded by the Independence Mountains to the west, the south end of the Jarbidge Mountains to the northeast, and the Adobe Range to the southeast. The lower basin is bounded by the Adobe Range and Peko Hills to the west and east, respectively, the south end of the Jarbidge Mountains to the north, and the Humboldt River to the south. The two basins are connected by the North Fork Humboldt River which flows through an unnamed canyon at the north end of the Adobe Range.

Lamoille Valley covers an area of $257 \mathrm{mi}^{2}$ and is drained by Lamoille Creek and its tributaries (fig. 1). The area consists of Lamoille Canyon in the Ruby Mountains and a northwest sloping pediment bounded to the southeast by the Ruby Mountains, to the northwest by the Humboldt River, and by low topographic divides between the Starr Valley Area to the east and the Dixie Creek-Tenmile Creek Area to the west.

The South Fork Area covers $99 \mathrm{mi}^{2}$ and is drained by the South Fork Humboldt River and its tributaries (fig. 1). The area is bounded by topographic divides between the Dixie Creek-Tenmile Creek Area to the north and Huntington Valley to the south. The two divides converge to the northwest and join at the confluence of the South Fork Humboldt River and Huntington Creek. The Ruby Mountains form the high-altitude uplands of the area.

Huntington Valley covers $787 \mathrm{mi}^{2}$ and is drained by Huntington Creek and by several tributaries that originate in the northeast part of the area. The area is bounded by the Ruby Mountains to the east, by the Pinion Range and Diamond Mountains to the west, by a low topographic divide to the south, and by the South Fork and Dixie Creek-Tenmile Creek Areas to the north. 
The Dixie Creek-Tenmile Creek Area covers $392 \mathrm{mi}^{2}$ and is drained by the South Fork Humboldt River and its two main tributaries in the area-Dixie and Tenmile Creeks (fig. 1). Since December 1987, flow has been regulated by the South Fork Reservoir, which has a maximum altitude of 5,231.4 ft. The Dixie Creek-Tenmile Creek Area is bounded by the South Fork Area and Huntington Valley to the south, Lamoille Valley to the east, the Pinion Range to the west, and to the north, by a group of unnamed hills that extend from the Elko Hills to the north end of the Pinion Range.

The Elko Segment covers $314 \mathrm{mi}^{2}$ and consists of the Humboldt River flood plain and adjacent uplands (fig. 1). The area is bounded by the Adobe Range to the north and the Elko Hills and north end of the Pinion Range to the south.

\section{Previous Studies}

One of the earliest water-resources investigations in the Humboldt River basin was done by the USGS in the early to middle 1960s (Eakin and Lamke, 1966). They divided the Humboldt River basin into upper, middle, and lower basins, and their study describes the hydrologic processes, water budgets, and general water chemistry of the entire basin. At the same time, the USGS also evaluated the water resources of Huntington Valley and the South Fork and Dixie CreekTenmile Creek Areas (Rush and Everett, 1966). The results of phase one of the present study provide general information on the hydrogeologic framework of the upper basin, and the occurrence and movement of groundwater in the eight hydrographic areas that make up the upper basin (Plume, 2009).

\section{Methods Used in this Study}

Several methods of investigation were used during the course of this study to provide information needed to characterize hydraulic properties of basin-fill deposits, develop a water budget, and define interactions between groundwater and surface water. The lithology of basin-fill deposits, expressed as percent of fine-grained sediments, was determined from well drillers' logs filed with the NDWR and available at $h t t p: / / w a t e r . n v . g o v / d a t a / w e l l l o g /$. Percentages of fine-grained sediments in the upper $200 \mathrm{ft}$ of basin fill were determined from 354 well logs. Well logs also were used to estimate the transmissivity of basin-fill aquifers using values of specific capacity determined from drillers' logs that report a pumping test after completion of the well.

Estimates of subsurface flow are used in this report to quantify the amount of groundwater outflow at eight aquifer cross sections. The method uses the equation:

$$
Q=0.0084 T w i
$$

where

$Q$ is the quantity of subsurface flow, in acre-feet per year,

$T$ is the transmissivity of the aquifer in feet squared per day,

$w$ is the effective width of the aquifer flow section, in feet,

$i$ is the hydraulic gradient driving groundwater flow, in feet of water-level change per foot of horizontal distance, and

0.0084 is a factor to convert cubic feet per day to acre-feet per year.

Two of the eight sections are where groundwater leaves the upper Humboldt River basin, and six are at downgradient ends of hydrographic areas. Groundwater flow across each of these sections is discussed in the "Subsurface Flow" section of this report. The uncertainty of this method is such that estimates of subsurface flow are reported to only one significant figure.

Interconnections between groundwater and surface water are evaluated using measurements of (1) streamflow made at more than 100 sites on the upper Humboldt River and its tributaries in October 2008 and November 2009; and (2) continuous records of Humboldt River stage and water levels in shallow wells adjacent to the river near Elko.

\section{Hydrogeologic Setting}

The hydrogeologic framework of the upper Humboldt River basin was described in detail as part of phase one of the present study (Plume, 2009). Therefore, the general hydrogeology of the area is only summarized in this section of the report. However, the lithology and hydraulic properties of basin-fill deposits are discussed in some detail in this section.

\section{Summary of Hydrogeologic Units}

The upper Humboldt River basin consists of several deep structural basins in which basin-fill deposits of Quaternary and Tertiary age and volcanic rocks of Tertiary age have accumulated. The bedrock of each basin and adjacent mountains are composed of carbonate and clastic sedimentary rocks of Paleozoic age and metamorphic and granitic rocks of Cambrian, Jurassic and Tertiary age. As part of the phase one study, rocks and basin-fill deposits in the study area were grouped into six hydrogeologic units (fig. 2; table 2). The units, from oldest to youngest, are (1) carbonate rocks and interbedded clastic sedimentary rocks of Cambrian to Permian age, (2) clastic sedimentary rocks of Ordovician to Devonian age, (3) crystalline rocks consisting of granitic intrusive and metamorphic rocks of Cambrian, Jurassic and Tertiary age, (4) volcanic rocks of Tertiary age, (5) older basin-fill deposits of Tertiary and Quaternary age that compose most of the alluvial fill in each basin, and (6) younger basin-fill deposits of Quaternary age that consist mostly of deposits along stream flood plains. Basin-fill deposits and carbonate rocks can have relatively high permeability and transmit groundwater, whereas the other 


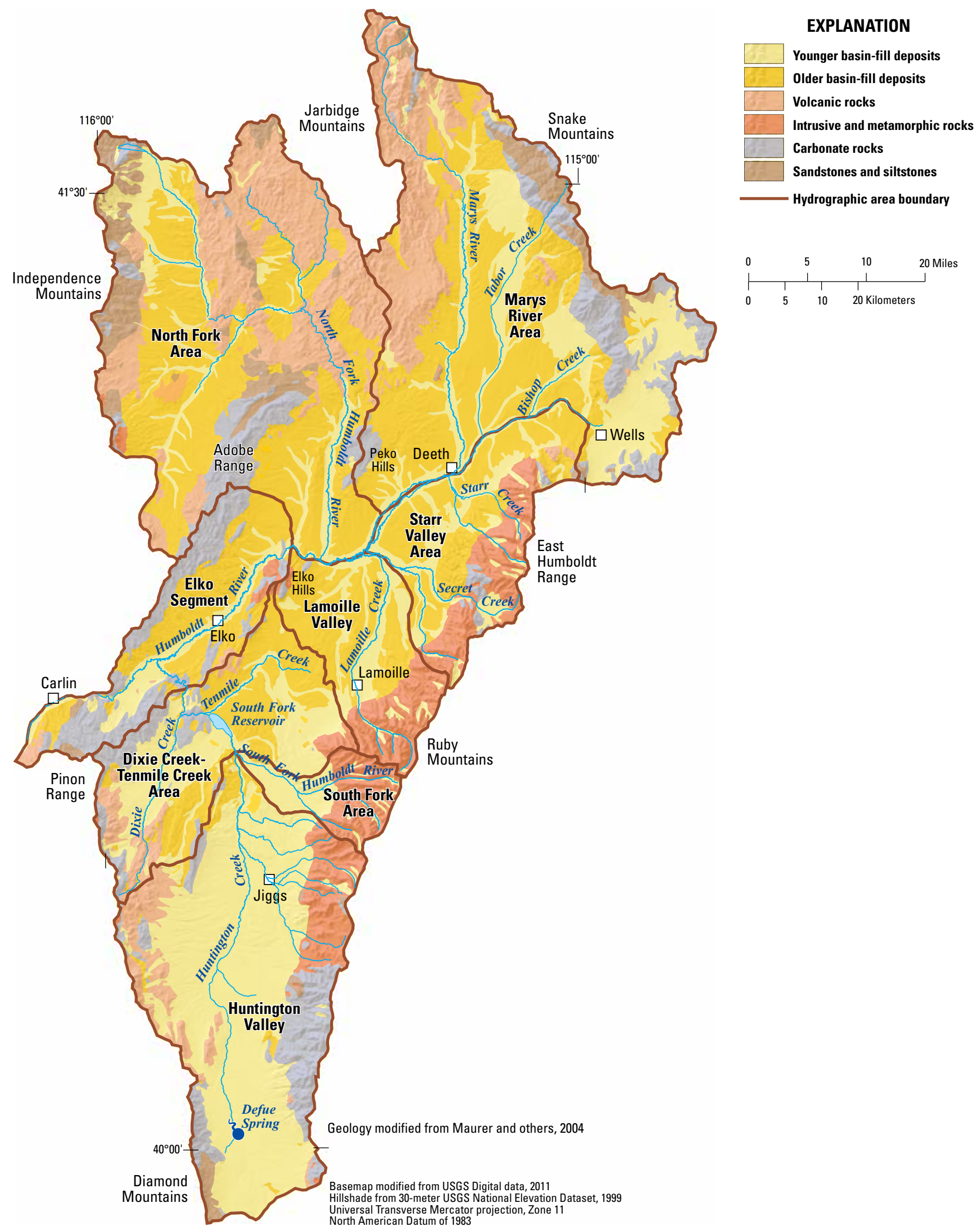

Figure 2. Hydrogeologic map of the upper Humboldt River basin, northeastern Nevada. 
Table 2. Lithology, thickness, extent, and water-bearing characteristics of hydrogeologic units in the upper Humboldt River basin, northeastern Nevada.

[Abbreviations: Mtn, Mountain; Fm, Formation]

\begin{tabular}{|c|c|c|c|c|c|}
\hline $\begin{array}{c}\text { Hydrogeologic } \\
\text { unit }\end{array}$ & Geologic age & Rock or stratigraphic unit & Lithology & Thickness and locality & $\begin{array}{l}\text { Water-bearing } \\
\text { characteristics }\end{array}$ \\
\hline $\begin{array}{l}\text { Younger basin- } \\
\text { fill deposits }\end{array}$ & Quaternary & Alluvium and glacial moraines & $\begin{array}{l}\text { Sorted and interbedded clay, } \\
\text { sand, and gravel along stream } \\
\text { flood plains. Poorly sorted to } \\
\text { unsorted clay, silt, sand, gravel, } \\
\text { and boulders of alluvial fans and } \\
\text { moraines. }\end{array}$ & $\begin{array}{l}\text { Deposits of flood plains probably } \\
\text { do not exceed a few tens of feet } \\
\text { in thickness. Moraines and de- } \\
\text { posits of alluvial fans probably } \\
\text { range from hundreds to more } \\
\text { than } 1,000 \text { feet thick. }\end{array}$ & $\begin{array}{l}\text { Together with older basin- } \\
\text { fill deposits, comprise } \\
\text { shallow water-table aqui- } \\
\text { fers and deeper confined } \\
\text { aquifers. }\end{array}$ \\
\hline $\begin{array}{l}\text { Older basin-fill } \\
\text { deposits }\end{array}$ & $\begin{array}{l}\text { Quaternary } \\
\text { and Tertiary }\end{array}$ & $\begin{array}{l}\text { Older alluvium of stream } \\
\text { terraces (Coats, 1987, p. } \\
\text { 70), sedimentary deposits of } \\
\text { the Miocene and Pliocene } \\
\text { Elko Basin (Wallace and } \\
\text { others, 2008, p. 59-62), and } \\
\text { limestone, conglomerate, } \\
\text { sandstone, shale, and tuff of } \\
\text { Oligocene to Paleocene age } \\
\text { (Coats, 1987, p. 51-62). }\end{array}$ & $\begin{array}{l}\text { Poorly consolidated deposits of } \\
\text { fluvial and lacustrine origin. In- } \\
\text { cludes deposits of alluvial fans, } \\
\text { stream flood plains, and shallow } \\
\text { lakes. Deposits commonly are } \\
\text { tuffaceous and are extensively } \\
\text { interbedded with volcanic rocks. }\end{array}$ & $\begin{array}{l}\text { Total thickness including inter- } \\
\text { bedded volcanic rocks ranges } \\
\text { from less than } 500 \text { feet mostly } \\
\text { along basin margins to more } \\
\text { than } 5,000 \text { feet in a deep and } \\
\text { narrow structural basin that ex- } \\
\text { tends from southern Huntington } \\
\text { Valley to northern Marys River } \\
\text { Area (fig. 2). }\end{array}$ & $\begin{array}{l}\text { Together with younger } \\
\text { basin-fill deposits, } \\
\text { comprise shallow water- } \\
\text { table aquifers and deeper } \\
\text { confined aquifers. }\end{array}$ \\
\hline Volcanic rocks & Tertiary & Volcanic rocks & $\begin{array}{l}\text { Ash-flow and air-fall tuffs, lava } \\
\text { flows, and domes. Lithologies } \\
\text { include basalt, andesite, dacite, } \\
\text { latite, and rhyolite (Coats, 1987, } \\
\text { pl. } 1 \text { and p. 51-67). }\end{array}$ & $\begin{array}{l}\text { Extensively interbedded with } \\
\text { older basin-fill deposits. See } \\
\text { above for composite thickness. }\end{array}$ & $\begin{array}{l}\text { Mostly impedes ground- } \\
\text { water flow because tuffs } \\
\text { weather to clay and } \\
\text { because of interbedded } \\
\text { fine-grained lake deposits. } \\
\text { Presence of perennial } \\
\text { streams in watersheds un- } \\
\text { derlain by these rocks also } \\
\text { indicates low permeability. }\end{array}$ \\
\hline \multirow[t]{2}{*}{$\begin{array}{l}\text { Metamorphic } \\
\text { and igneous } \\
\text { intrusive } \\
\text { rocks }\end{array}$} & $\begin{array}{l}\text { Cambrian and } \\
\text { Jurassic }\end{array}$ & Metamorphic rocks & $\begin{array}{l}\text { Metamorphic rocks include } \\
\text { marble, schist, and gneiss. They } \\
\text { are metamorphosed carbonate } \\
\text { and siliciclastic sedimentary } \\
\text { rocks of Paleozoic age in the } \\
\text { central and northern Ruby Mtns } \\
\text { and Elko Hills. }\end{array}$ & \multirow[t]{2}{*}{$\begin{array}{l}\text { Extend to great depths and can } \\
\text { be much more extensive than } \\
\text { indicated by outcrop area. }\end{array}$} & \multirow[t]{2}{*}{$\begin{array}{l}\text { Impedes the movement of } \\
\text { groundwater. }\end{array}$} \\
\hline & $\begin{array}{l}\text { Jurassic and } \\
\text { Tertiary }\end{array}$ & Granitic intrusive rocks & $\begin{array}{l}\text { Granitic rocks consist of grano- } \\
\text { diorite in the central Ruby Mtns } \\
\text { and alaskite in the southern } \\
\text { Independence Mtns. }\end{array}$ & & \\
\hline
\end{tabular}

rock units generally have low permeability and impede the flow of groundwater. The lithology and water-bearing properties of each unit are summarized in table 2 .

\section{Basin-Fill Deposits}

The principal aquifers in the upper Humboldt River basin are the basin-fill deposits that underlie each of the hydrographic areas to depths of up to several thousand feet or more (Plume, 2009, p. 8-11). The basin-fill deposits are subdivided into younger and older based on lithology and occurrence. Younger basin-fill deposits occur as unconsolidated, sorted sand and gravel with interbedded clay and silt along the flood plains of active stream channels and as heterogeneous deposits on alluvial aprons between mountain fronts and basin lowlands. Deposits along stream flood plains are probably no thicker than a few tens of feet.

The oldest basin-fill deposits in the study area are of Eocene and earliest Oligocene age, are interbedded with volcanic rocks, and are mostly north of the Humboldt River. They consist of a basal conglomerate overlain by a sequence of welded tuffs, deposits of the Elko Formation (claystone, siltstone, shale, limestone, and tuff), and rhyolitic lava flows and domes (Coats, 1987, p. 51-58). All of the basin-fill deposits are tuffaceous to differing extents. The total thickness exceeds $3,000 \mathrm{ft}$ although these rocks and deposits apparently do not constitute a continuous blanket over northern parts of the study area. According to Henry (2008), these rocks and deposits accumulated in and along a minimum of three deep and wide eastward draining valleys during Eocene time. The valleys were separated by uplands on which any air-fall tuffs were eroded and deposited in lowlands of each valley. From late Eocene to middle Miocene the upper Humboldt River basin was an area probably undergoing erosion, because deposits and volcanic rocks of this age span are not present.

Since middle Miocene time three geologic events have affected the distribution, lithology, and water-bearing properties of basin-fill deposits in the upper Humboldt River basin: 
Table 2. Lithology, thickness, extent, and water-bearing characteristics of hydrogeologic units the upper Humboldt River basin, northeastern Nevada.-Continued

\begin{tabular}{|c|c|c|c|c|c|}
\hline $\begin{array}{c}\text { Hydrogeologic } \\
\text { unit }\end{array}$ & Geologic age & Rock or stratigraphic unit & Lithology & Thickness and locality & $\begin{array}{l}\text { Water-bearing } \\
\text { characteristics }\end{array}$ \\
\hline \multirow[t]{2}{*}{$\begin{array}{l}\text { Clastic } \\
\text { sedimentary } \\
\text { rocks }\end{array}$} & $\begin{array}{l}\text { Devonian to } \\
\text { Ordovician }\end{array}$ & $\begin{array}{l}\text { Woodruff Fm } \\
\text { Valmy Fm } \\
\text { Vinini Fm }\end{array}$ & $\begin{array}{l}\text { Shale, siltstone, sandstone, quartz- } \\
\text { ite, chert, and marine volcanic } \\
\text { rocks. These rocks are part of } \\
\text { the upper plate of the Roberts } \\
\text { Mtns thrust and they structurally } \\
\text { overlie, along the thrust, various } \\
\text { units of carbonate rocks that are } \\
\text { part of the lower plate. }\end{array}$ & $\begin{array}{l}\text { Thickness about 2,000 feet in the } \\
\text { Snake Mtns, 9,000 feet in north- } \\
\text { ern Independence Mtns, } 4,700 \\
\text { feet in the Pinyon Range, and } \\
4,000-10,000 \text { feet in the Ruby } \\
\text { Mtns (Coats, } 1987 \text {, p. } 10-13 \text { and } \\
\text { 29-34). }\end{array}$ & $\begin{array}{l}\text { Generally impedes move- } \\
\text { ment of groundwater. Pres- } \\
\text { ence of perennial streams } \\
\text { in watersheds underlain by } \\
\text { these rocks also indicates } \\
\text { low permeability. }\end{array}$ \\
\hline & $\begin{array}{l}\text { Permian, } \\
\text { Pennsylvanian } \\
\text { and Missis- } \\
\text { sippian }\end{array}$ & $\begin{array}{l}\text { Edna Mtn Fm } \\
\text { Schoonover Fm } \\
\text { Diamond Peak Fm } \\
\text { Chainman Shale } \\
\text { Webb Fm }\end{array}$ & $\begin{array}{l}\text { Shale, sandstone, sandy limestone, } \\
\text { conglomerate, and chert. Depo- } \\
\text { sitionally overlie various units of } \\
\text { carbonate rocks }\end{array}$ & \multirow[b]{2}{*}{$\begin{array}{l}\text { Thickness at least 20,000 feet in } \\
\text { the Ruby Mtns, 10,000 feet in } \\
\text { the Pinyon Range and Snake } \\
\text { Mtns, and about 4,000 feet in } \\
\text { the Independence Mtns. An oil } \\
\text { well penetrated 4,500 feet of } \\
\text { carbonate rocks from the Devils } \\
\text { Gate Limestone to the Hanson } \\
\text { Creek Fm at the north end of the } \\
\text { Pinyon Range (Coats, 1987, p. } \\
\text { 13-47). }\end{array}$} & \multirow[b]{2}{*}{$\begin{array}{l}\text { Comprise carbonate-rock } \\
\text { aquifers generally beneath } \\
\text { basin-fill aquifers. High } \\
\text { permeability due to solu- } \\
\text { tional widening of fracture } \\
\text { zones. Absence of peren- } \\
\text { nial streams in watersheds } \\
\text { even partly underlain by } \\
\text { these rocks indicates high } \\
\text { permeability. }\end{array}$} \\
\hline $\begin{array}{l}\text { Carbonate and } \\
\text { interbed- } \\
\text { ded clastic } \\
\text { sedimentary } \\
\text { rocks }\end{array}$ & $\begin{array}{l}\text { Permian to } \\
\text { Cambrian }\end{array}$ & $\begin{array}{l}\text { Phosphoria Fm } \\
\text { Strathearn Fm } \\
\text { Moleen Fm } \\
\text { Tomera Fm } \\
\text { Ely Limestone } \\
\text { Joana Limestone } \\
\text { Pilot Shale } \\
\text { Devils Gate Limestone } \\
\text { Nevada Formation } \\
\text { Lone Mtn Dolomite } \\
\text { Roberts Mtns Fm } \\
\text { Hanson Creek Fm } \\
\text { Eureka Quartzite } \\
\text { Pogonip Group } \\
\text { Windfall Fm } \\
\text { Dunderberg Shale } \\
\text { Hamburg Dolomite } \\
\text { Secret Canyon Shale } \\
\text { Geddes Limestone } \\
\text { Eldorado Dolomite } \\
\text { Pioche Shale } \\
\text { Prospect Mtn Quartzite }\end{array}$ & $\begin{array}{l}\text { Intervals of limestone and } \\
\text { dolomite interrupted by thinner } \\
\text { intervals of shale, quartzite, and } \\
\text { conglomerate. All units rarely } \\
\text { present in a single mountain } \\
\text { range. Underlie entire study } \\
\text { area, but are concealed over } \\
\text { large parts of mountain ranges } \\
\text { by various units of siliciclastic } \\
\text { sedimentary rocks. }\end{array}$ & & \\
\hline
\end{tabular}

(1) structural formation and filling of the Miocene Elko basin, (2) formation of a Pliocene lake in part of the Elko basin, and (3) glaciation mostly in the Ruby Mountains-East Humboldt Range. Beginning about 15-14 Ma (millions of years before present), the Elko basin began to form as a result of low-angle and high-angle faulting along the west sides of the Ruby Mountains, East Humboldt Range, and Snake Mountains (Wallace and others, 2008, p. 58-61). The Miocene Elko basin was large, extending from what is now southern Huntington Valley to northern Marys River and from the Ruby MountainsEast Humboldt Range-Snake Mountains on the east to the Adobe and Pinion Ranges on the west (fig. 3; Wallace and others, 2008, p. 58). Materials eroded from these mountain ranges spread across the basin accumulating as fine-grained lake sediments in lowlands and as alluvial fan and stream flood plain sediments toward basin margins. In addition to sediments derived from the mountains, air-fall tuffs mostly from distant sources accumulated in the sediments. This pattern of deposition continued into the late Miocene (10-9 Ma) when the Elko basin began to drain externally, resulting in non-deposition of sediments and erosion of existing ones (Wallace and others, 2008, p. 63).

Non-deposition, erosion, and transport of sediments out of the Elko basin continued from the late Miocene through the Pleistocene except for a period in the middle Pliocene when external drainage was blocked forming a lake in which fluvial and lacustrine sediments accumulated along basin margins and in lowlands, respectively (Wallace and others, 2008, p. 61). This lake persisted until the late Pliocene when external drainage resumed. The Pliocene lake was smaller than the Elko basin, extending southwest from the central Marys River Area to the South Fork Humboldt River between the Ruby Mountains on the east and the Peko and Elko Hills on the west (fig. 3). It also extended along the Humboldt River flood plain between the Elko Hills and Adobe Range as far as Carlin (fig. 3; Wallace and others, 2008, fig. 10). The Pliocene lake deposits are as thick as $900 \mathrm{ft}$ at a drill hole east of the Elko Hills (Wallace and others, 2008, p. 61). 


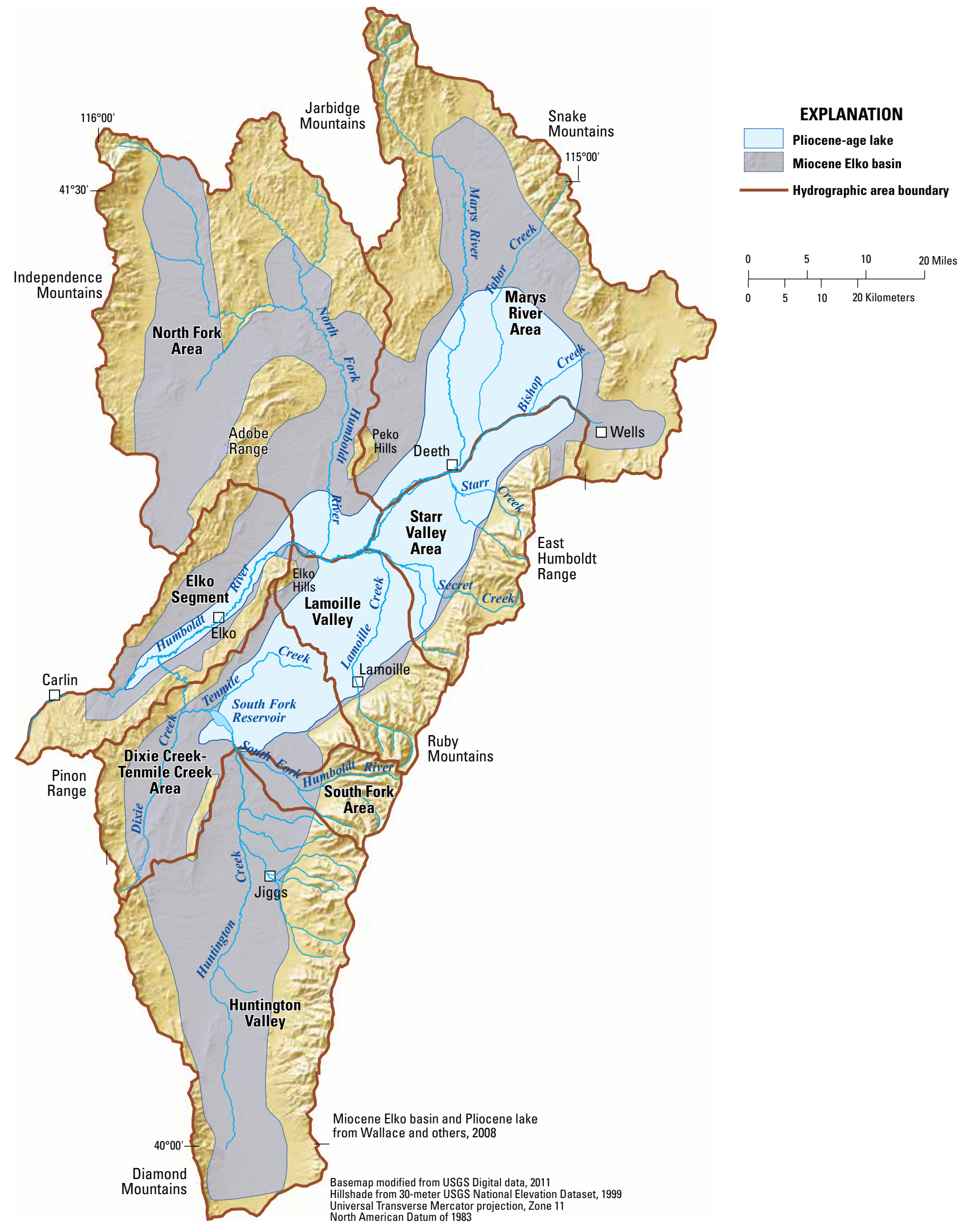

Figure 3. Extent of Miocene Elko basin and Pliocene lake, upper Humboldt River basin, northeastern Nevada. 
The Ruby Mountains, East Humboldt Range and northern Independence Mountains were glaciated during two substages, the Lamoille and Angel Lake, from 300,000-130,000 and 110,000-10,000 years ago, respectively (Sharp, 1938; Coats, 1987, p. 71; and Howard, 2000). During both substages, glacial outwash deposits accumulated on pediments adjacent to the Ruby Mountains and East Humboldt Range in the Starr Valley Area, Lamoille Valley, the Dixie Creek-Tenmile Creek and South Fork Areas, and in Huntington Valley as far as 10 to15 miles (mi) south of Jiggs (Sharp, 1938). Outwash also accumulated in northernmost parts of the Independence Mountains in the North Fork Area (Sharp, 1938; and Coats, 1987, p. 71). In addition to outwash deposits, glaciation in Lamoille Canyon deposited moraines as far as a mile north of the canyon mouth during the Lamoille substage (Sharp, 1938, p. 303-304 and 319; and Howard, 2000). Outwash deposits of the Lamoille substage consist of sand and gravel near the mouth of Lamoille Canyon and, with increasing distance from the canyon mouth, sand, gravel, and interbedded sandstone, siltstone, and claystone (Howard, 2000). Outwash deposits of the Angel Lake substage consist of sand and gravel north of Lamoille Canyon (Howard, 2000).

\section{Lithology}

Drillers' well logs filed with the NDWR were used to define the areal distribution of fine-grained sediments (clay and silt) in the study area and their proportion relative to coarsegrained deposits (sand and gravel) in the upper $200 \mathrm{ft}$ of basin fill. The approach used was to select logs from the NDWR website (http://water.nv.gov/data/welllog/) for all wells $200 \mathrm{ft}$ or deeper. The initial result yielded over 4,100 records, each representing a well at least $200 \mathrm{ft}$ deep in the upper Humboldt River basin. A subset of these well log records was selected for analysis and as a result the number of well logs examined was reduced to 354 .

The symbols on figure 4 each represent a well where the amount of fine-grained sediments in the upper $200 \mathrm{ft}$ is 0 to less than 30,30 to less than 70 , or 70 to 100 percent. The total thickness of clay and silt plus one-half the total thickness of intervals such as sandy or gravelly clay, or clayey or silty gravel, or sand was divided by 200 to compute the percent of fine-grained sediments penetrated by the well. Following are two examples: (1) for a log that records $200 \mathrm{ft}$ of sandy clay, the proportion of fine-grained sediments is 50 percent $(200 \mathrm{ft}$ divided by $2=100 \mathrm{ft}$ of fine-grained materials divided by 200 $=50$ percent); and (2) for a $\log$ that records $100 \mathrm{ft}$ of clay, $40 \mathrm{ft}$ of gravel, and $60 \mathrm{ft}$ of sandy clay, the proportion of finegrained sediments is 65 percent $(60 \mathrm{ft}$ divided by $2+100 \mathrm{ft}=$ $130 \mathrm{ft}$ of fine-grained materials divided by $200=65$ percent). Figure 4 shows the distribution of fine-grained sediments (clay and silt) and, by inference, the distribution of coarse-grained sediments (sand and gravel) in the upper $200 \mathrm{ft}$ of basin fill in the upper Humboldt River basin.

Fine-grained sediments compose anywhere from 30 to more than 70 percent of the upper $200 \mathrm{ft}$ of basin-fill deposits over nearly all of the area covered by the Pliocene lake. The main exception to this is in the area between the mouth of Lamoille Canyon and the Elko Hills along and on both sides of the boundary between Lamoille Valley and the Dixie CreekTenmile Creek Area (fig. 4). The presence of coarse-grained sediments in this area is the result of large floods originating in Lamoille Canyon mostly during the Pleistocene, when the Lamoille and Angel Lake glacial substages produced large volumes of outwash and moraines beyond the mouth of the canyon (Sharp, 1938; and Howard 2000). Fine-grained sediments compose from 30 to more than 70 percent of the upper $200 \mathrm{ft}$ of basin-fill deposits in most of the Marys River Area, southernmost North Fork Area, Starr Valley Area, and the Elko Segment along the Humboldt River flood plain. However, coarse-grained sediments also are common between the flood plain and Adobe Range as alluvial fan deposits and at the mouth of the North Fork Humboldt River, possibly as river delta deposits. The Pliocene lake did not extend into the South Fork Area or Huntington Valley and fine-grained sediments are not as predominant in the basin fill. However, coarse-grained sediments are common on the east sides of both areas, as a result of deposition of glacial outwash.

\section{Transmissivity}

The specific capacity of a well, expressed as gallons per minute per foot of drawdown, is determined from the results of a pumping test, and is computed as the average pumping rate, in gallons per minute, divided by the total water-level drawdown, in feet, measured at the end of the test. Specific capacity is generally considered to be proportional to the transmissivity of the aquifer yielding water to the well, especially with increasing time (Lohman and others, 1972, p. 11). Thomasson and others (1960, p. 222) found that specific capacity multiplied by 230 yields a reasonably good estimate of transmissivity (in feet squared per day).

The areal distribution of transmissivity in basin-fill aquifers in the upper Humboldt River basin (fig. 5) was determined from the results of drillers' pumping tests reported on logs filed with the NDWR (http://water.nv.gov/data/welllog/). Test results are reported on a driller's log as pumping rate, in gallons per minute, water-level drawdown below original static water level, in feet, and pumping time usually in hours. The NDWR website has summaries of logs that include specific capacity for more than 4,000 wells in the upper Humboldt River basin. Two criteria were used to pare such a large data set down to manageable size and to reject questionable tests. Only well logs with tests of 1 hour or more duration and with pumping rates of at least 25 gallons per minute ( $\mathrm{gal} / \mathrm{min}$ ) were used. ${ }^{2}$ The resulting data set consisted of 332 estimates of specific capacity that were multiplied by 230 to obtain estimated transmissivity.

\footnotetext{
2 This restriction on a minimum pumping rate could skew transmissivity toward higher values. However, low pumping rates do not always adequately stress an aquifer and can result in inaccurate values of specific capacity.
} 


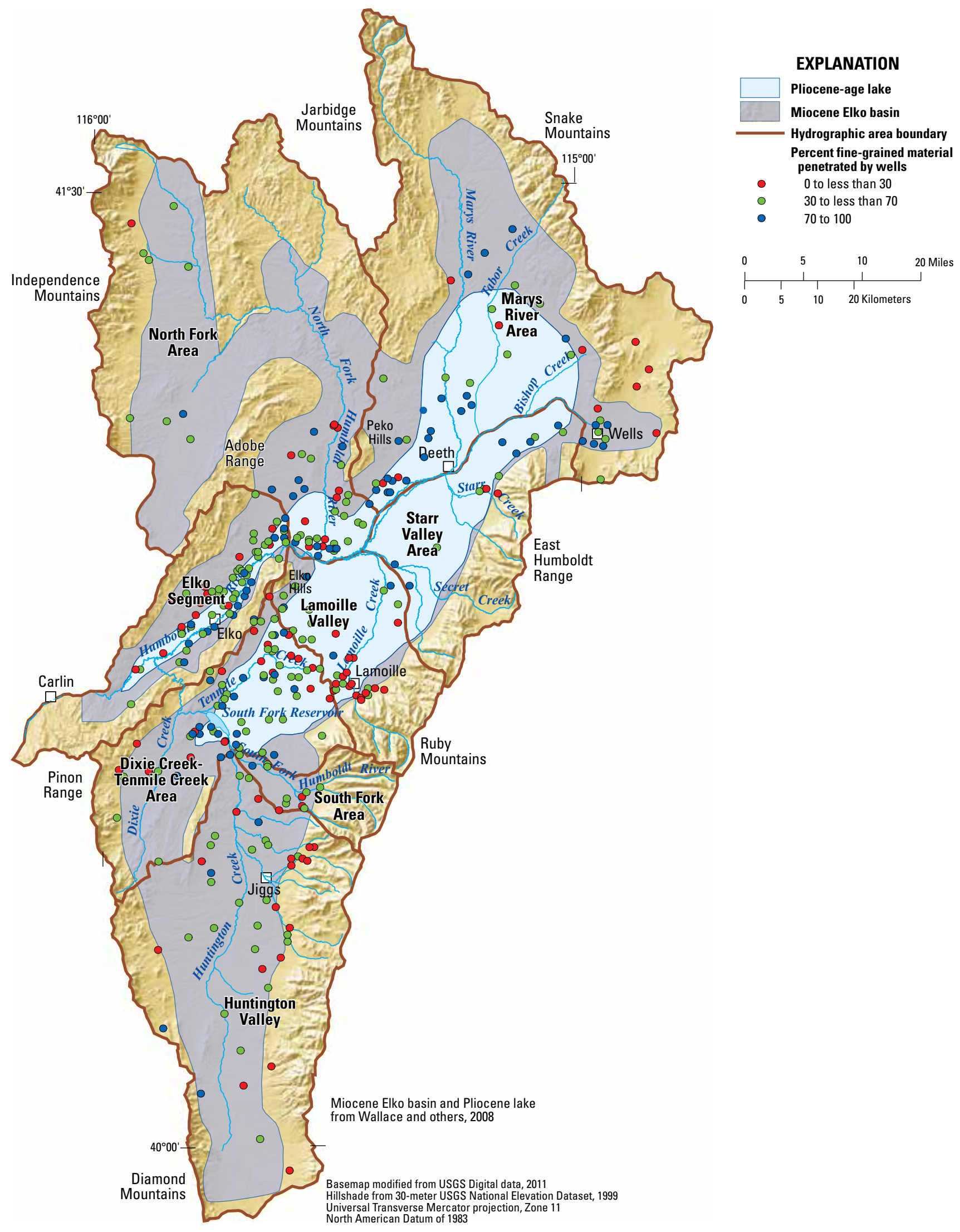

Figure 4. Extent of Miocene Elko basin, Pliocene lake, and percentages of fine-grained sediments in upper 200 feet of basin fill, upper Humboldt River basin, northeastern Nevada. 


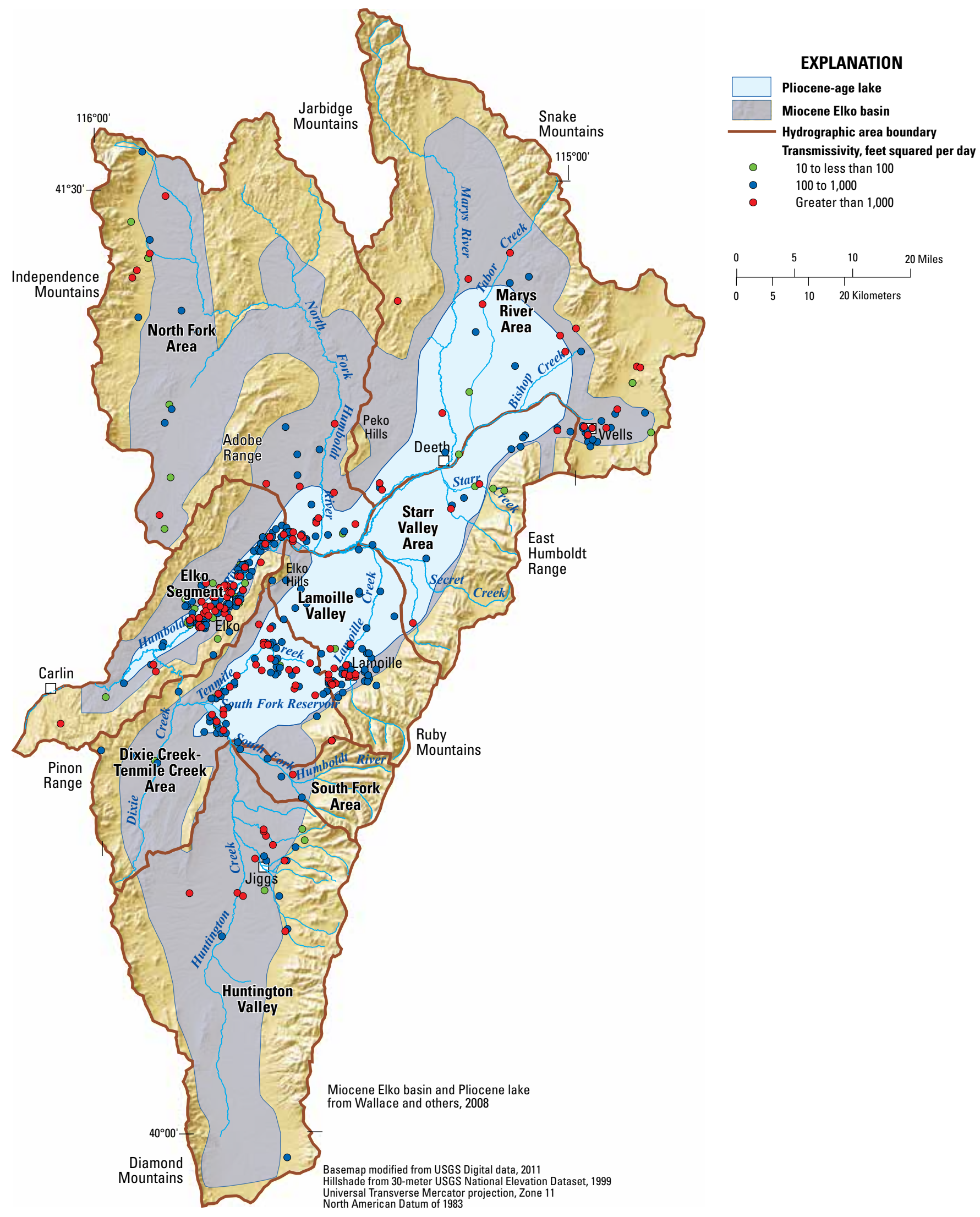

Figure 5. Extent of Miocene Elko basin, Pliocene lake, and estimated transmissivity of basin-fill deposits, upper Humboldt River basin, northeastern Nevada. 
The areal distribution of the transmissivity of basinfill aquifers in the upper Humboldt River basin is shown on figure 5 in intervals of 10 to 100 feet squared per day $\left(\mathrm{ft}^{2} / \mathrm{d}\right), 100$ to $1,000 \mathrm{ft}^{2} / \mathrm{d}$, and greater than 1,000 to less than $10,000 \mathrm{ft}^{2} / \mathrm{d}$. The greatest transmissivities are clustered in three areas. High transmissivities northwest of Lamoille Canyon are attributed to coarse-grained glacial outwash of Pleistocene age. The high transmissivities below the confluence of Huntington Creek and the South Fork Humboldt River might also be attributed to coarse-grained outwash from the South Fork Area; however, proportions of fine-grained sediments in the upper $200 \mathrm{ft}$ of basin fill in this area are relatively high (fig. 4) suggesting that transmissivities should be low. Three of the wells with high transmissivities are less than $200 \mathrm{ft}$ deep and were not used for the analysis of fine-grained sediments discussed above. Further, the logs for the wells show substantial thicknesses of clay with interbedded sand and gravel. This illustrates the importance of relatively thin intervals of coarse-grained sediments even when they are separated by thicker intervals of clay. The transmissivity of deposits along and adjacent to the Humboldt River flood plain northeast and southwest of Elko agree with the distribution of fine- and coarse-grained sediments shown in figure 4. Both illustrate the heterogeneity of the deposits in the flood plain and the adjacent alluvial fans, and of the deposits in the Pliocene lake.

Table 3 lists mean, median, minimum, and maximum values of estimated transmissivity for each hydrographic area in the upper Humboldt River basin. Mean values in the table are rounded to one significant figure due to uncertainty of the estimates. For the most part, mean values of transmissivity range from more than 500 to less than $900 \mathrm{ft}^{2} / \mathrm{d}$. The exceptions are the Starr Valley and South Fork Areas where mean values of transmissivity are $300 \mathrm{ft}^{2} / \mathrm{d}$. Mean values of transmissivity in table 3 were used for estimating subsurface flow across eight aquifer sections in the "Subsurface Flow" section of this report.

Table 3. Summary statistics for transmissivity of basin-fill aquifers in the upper Humboldt River basin, northeastern Nevada.

\begin{tabular}{lccccc}
\hline \multirow{2}{*}{ Hydrographic area } & $\begin{array}{c}\text { Number } \\
\text { of }\end{array}$ & \multicolumn{3}{c}{ Transmissivity (feet squared per day) } \\
\cline { 3 - 6 } samples & Mean' & Median & Minimum & Maximum \\
\hline Marys River & 32 & 700 & 544 & 82 & 2,182 \\
\hline Starr Valley & 10 & 300 & 179 & 54 & 690 \\
\hline North Fork & 29 & 500 & 215 & 83 & 2,056 \\
\hline Lamoille Valley & 39 & 900 & 460 & 95 & 5,750 \\
\hline South Fork & 3 & 300 & 169 & 122 & 460 \\
\hline Huntington Valley & 9 & 600 & 719 & 38 & 1,314 \\
\hline Dixie Creek-Tenmile Creek & 56 & 900 & 521 & 41 & 4,259 \\
\hline Elko Segment & 133 & 700 & 276 & 21 & 8,353 \\
\hline
\end{tabular}

${ }^{1}$ Values rounded to one significant figure.

\section{Water-Budget Components}

Two types of water budgets can be developed for hydrographic areas in Nevada - groundwater budgets and total water budgets. Components of inflow to either type of budget consist mostly of annual precipitation and, to a lesser extent, subsurface inflow from adjacent areas. Components of outflow consist mostly of evapotranspiration (ET) and, to a lesser extent, streamflow and subsurface flow to adjacent areas. The difference between the two types of budgets is that groundwater budgets are developed for hydrographic areas where streamflow is minor or is along a through-flowing stream, whereas total water budgets are developed for areas where streamflow is a substantial part of the budget and is hydrologically connected with groundwater such that the contribution of each cannot be individually quantified. For instance, ET in riparian areas along streams consumes both groundwater and streamflow; however, the individual contribution of each cannot be quantified. Some of the earliest water-resources studies in the upper Humboldt River basin recognized the futility of attempting to quantify groundwater recharge (Eakin and Lamke, 1966, p. 31; and Rush and Everett, 1966, p. 26-27). For these reasons, no attempt was made to develop a groundwater budget for the upper Humboldt River basin; instead, a total water budget was developed for the 30-year period, 1971-2000, using the following inflow-outflow relation (values in acre-ft/yr):

$$
P_{\mathrm{t}}=E T_{\mathrm{p}}+E T_{\mathrm{n}}+S W_{\mathrm{o}}+G W_{\mathrm{o}}+P
$$

where
$P_{\mathrm{t}} \quad$ is average annual precipitation;
$E T_{\mathrm{p}}$ is basin-wide evapotranspiration of precipitation and includes evapotranspiration of soil moisture originating from precipitation and sublimation of snowpack;
$E T_{\mathrm{n}}$ is net evapotranspiration in discharge areas only, and it is the evapotranspiration in excess of $\mathrm{ET}_{p}$ and originates from groundwater, open water, and irrigated crops;
$S W_{\mathrm{o}} \quad$ is average annual flow of the Humboldt River near Carlin;
$G W_{\text {o }}$ is subsurface outflow of groundwater; and $\stackrel{\circ}{P}$ is pumpage.

$$
E T_{\mathrm{t}}=E T_{\mathrm{p}}+E T_{\mathrm{n}}
$$

where

$E T_{t} \quad$ is total ET.

Equation (2) would also include an additional term for a basin where changes in groundwater storage have occurred. However, net changes in storage are believed to be negligible in comparison with the other water-budget components during the period 1971-2000. Each of the water-budget components discussed below is an estimate based on the best available data. Even so, the uncertainty of the estimates can be as much as 25 percent. 


\section{Precipitation Distribution for the Period 1971-2000}

Annual precipitation is the only source of inflow to the upper Humboldt River basin; there is no evidence of subsurface flow from any adjacent hydrographic area. The distribution of precipitation shown in figure 6 was developed using PRISM for the period 1971-2000. PRISM is an acronym for Parameter-Elevation Regressions on Independent Slopes Model (Daly and others, 1994). PRISM uses point measurements of climatic data to produce continuous, digital grid estimates of climatic parameters, in this case precipitation. The method is described in detail by Jeton and others (2006, p. 3-6).

Average annual precipitation in the upper Humboldt River basin during the period 1971-2000 ranged from 8 to 11 inches per year (in/yr) in lowland areas to $46 \mathrm{in} / \mathrm{yr}$ in the highest parts of the East Humboldt Range and Ruby, Independence, Snake and Jarbidge Mountains (fig. 6; table 4). The total annual volume of precipitation is an estimated 3,330,000 acre-ft/yr. Among the eight hydrographic areas of the upper Humboldt River basin, the Elko Segment received the least precipitation, about 191,000 acre-ft/yr, and the Marys River Area received the most, about 795,000 acre-ft/yr. Mean annual precipitation ranged from $11.4 \mathrm{in} / \mathrm{yr}$ in the Elko Segment to $23.2 \mathrm{in} / \mathrm{yr}$ in the South Fork Area.

Estimates of annual precipitation using PRISM are uncertain, and, as a result, values predicted by the PRISM model can differ from values recorded at weather stations. The uncertainty of PRISM estimates of annual precipitation in the upper Humboldt River basin for the 1971-2000 period generally are within plus or minus 15 percent (Jeton and others, 2006, figs. 10 and 11). However, the uncertainty of PRISM estimates tends to increase with increasing altitude; uncertainties at two sites in the Ruby Mountains are 54 percent at one and -60 percent at the other (Jeton and others, 2006, fig. 11).

\section{Evapotranspiration}

Evapotranspiration is by far the largest outflow component of the upper Humboldt River basin water budget. It is also the most uncertain. Evapotranspiration is a process by which water at the Earth's surface is transferred to the atmosphere and involves two separate but related processes - evaporation and transpiration. Direct evaporation occurs from open water, shallow groundwater, soil moisture, and sublimation of snowpack. Transpiration is the process by which plants take up water through their roots and release it as vapor from the plant surface.

The upper Humboldt River basin can be divided into two types of areas: (1) discharge areas where total evapotranspiration $\left(E T_{t}\right)$ is greater than precipitation $\left(P_{t}\right)$ with the difference being net evapotranspiration $\left(E T_{\mathrm{n}}\right)$; and (2) non-discharge areas where $E T_{\mathrm{t}}$ is equal to evapotranspiration of precipitation $\left(E T_{\mathrm{p}}\right)$ and is less than or equal to $P_{\mathrm{t}}$.

Discharge areas represent areas where evapotranspiration of shallow groundwater $\left(E T_{\mathrm{g}}\right)$, open water $\left(E T_{\mathrm{w}}\right)$, and water from irrigated crops $\left(E T_{\mathrm{ag}}\right)$ occurs. The sum of $E T_{\mathrm{g}}, E T_{\mathrm{w}}$, and $E T_{\mathrm{ag}}$ is equivalent to $E T_{\mathrm{n}}$. $E T_{\mathrm{g}}$ mainly occurs through transpiration by phreatophytic vegetation, which includes shrubs, meadows, and riparian areas. Areas of shallow groundwater generally occur near streams, springs, and in low topographic areas. $E T_{\mathrm{w}}$ occurs as evaporation and is from open water along streams, lakes, and reservoirs. $E T_{\text {ag }}$ occurs mainly as crop transpiration and evaporation of irrigation water and soil moisture originating from irrigation water. Irrigated crop areas occur mostly along the Humboldt River and its tributaries but can be away from surface water if groundwater pumpage is the source of irrigation supply. $E T_{\mathrm{t}}$ from discharge areas is the sum of $E T_{\mathrm{p}}$ and $E T_{\mathrm{n}} \cdot E T_{\mathrm{p}}$ is assumed to be equal to $P_{\mathrm{t}}$ in discharge areas.

Non-discharge areas represent the rest of the area in the upper Humboldt River basin and $E T_{\mathrm{t}}$ is equal to $E T_{\mathrm{p}}$. In nondischarge areas, $E T_{\mathrm{t}}$ is less than $P_{\mathrm{t}}$ when precipitation results in runoff or infiltration to the water table.
Table 4. Summary statistics for annual precipitation, 1971-2000, in hydrographic areas of the upper Humboldt River basin, northeastern Nevada.

\begin{tabular}{lccccc}
\hline \multicolumn{1}{c}{ Hydrographic area } & $\begin{array}{c}\text { Minimum } \\
\text { (inches') }\end{array}$ & $\begin{array}{c}\text { Maximum } \\
\text { (inches') }\end{array}$ & $\begin{array}{c}\text { Mean } \\
\text { (inches') }\end{array}$ & $\begin{array}{c}\text { Area } \\
\text { (acres) }\end{array}$ & $\begin{array}{c}\text { Annual } \\
\text { precipitation } \\
\text { (acre-feet/year) }\end{array}$ \\
\hline Marys River & 10.4 & 45.6 & 13.9 & 686,720 & 795,451 \\
\hline Starr Valley & 10.7 & 45.4 & 18.1 & 212,480 & 320,491 \\
North Fork & 9.9 & 44.7 & 13.2 & 710,400 & 781,440 \\
\hline Lamoille Valley & 10.8 & 35.9 & 17.1 & 164,480 & 234,384 \\
\hline South Fork & 11.1 & 36.7 & 23.2 & 63,360 & 122,496 \\
\hline Huntington Valley & 9.9 & 40 & 14.7 & 503,680 & 617,008 \\
Dixie Creek-Tenmile Creek & 10.2 & 32.4 & 13 & 250,880 & 271,787 \\
\hline Elko Segment & 8.2 & 15.7 & 11.4 & 200,960 & 190,912 \\
\hline \multicolumn{1}{l}{${ }^{2}$ Determined from precipitation grid (fig. 6). } & & &
\end{tabular}

\section{Net Evapotranspiration}

Discharge areas in the upper Humboldt River basin were delineated in the summer of 2009 using a combination of remote sensing techniques and field mapping (fig. 7). Discharge areas were further classified into areas of similar vegetation type and similar $E T_{\mathrm{n}}$ rates and are called ET units. $E T_{\mathrm{n}}$ rates were estimated for each of the ET units by extrapolation from rates measured in similar environments outside the upper Humboldt River basin. Outflow resulting from $E T_{\mathrm{n}}$ was estimated by multiplying $E T_{\mathrm{n}}$ rates by respective ET unit areas. 


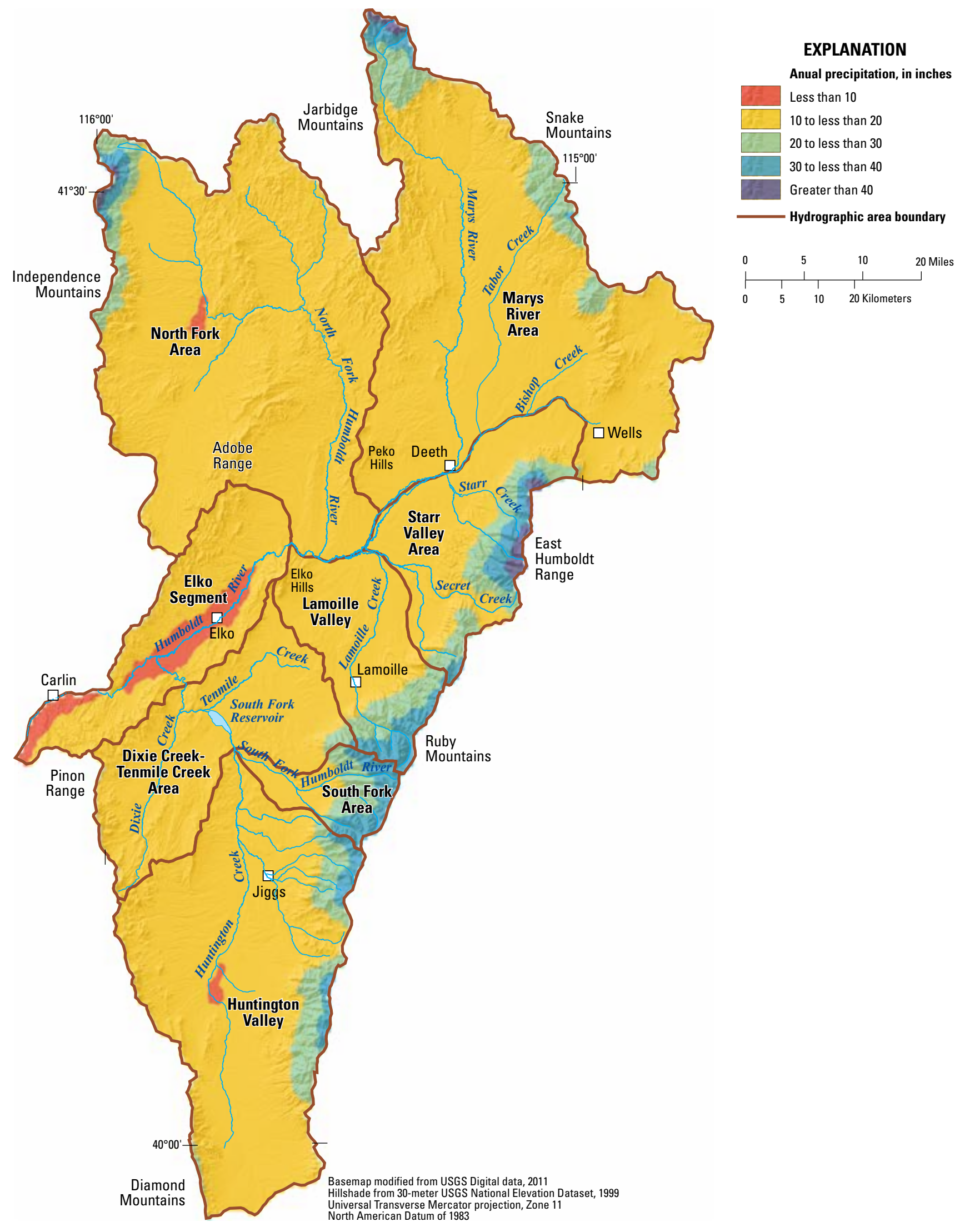

Figure 6. Distribution of estimated annual precipitation, 1971-2000, upper Humboldt River basin, northeastern Nevada. 


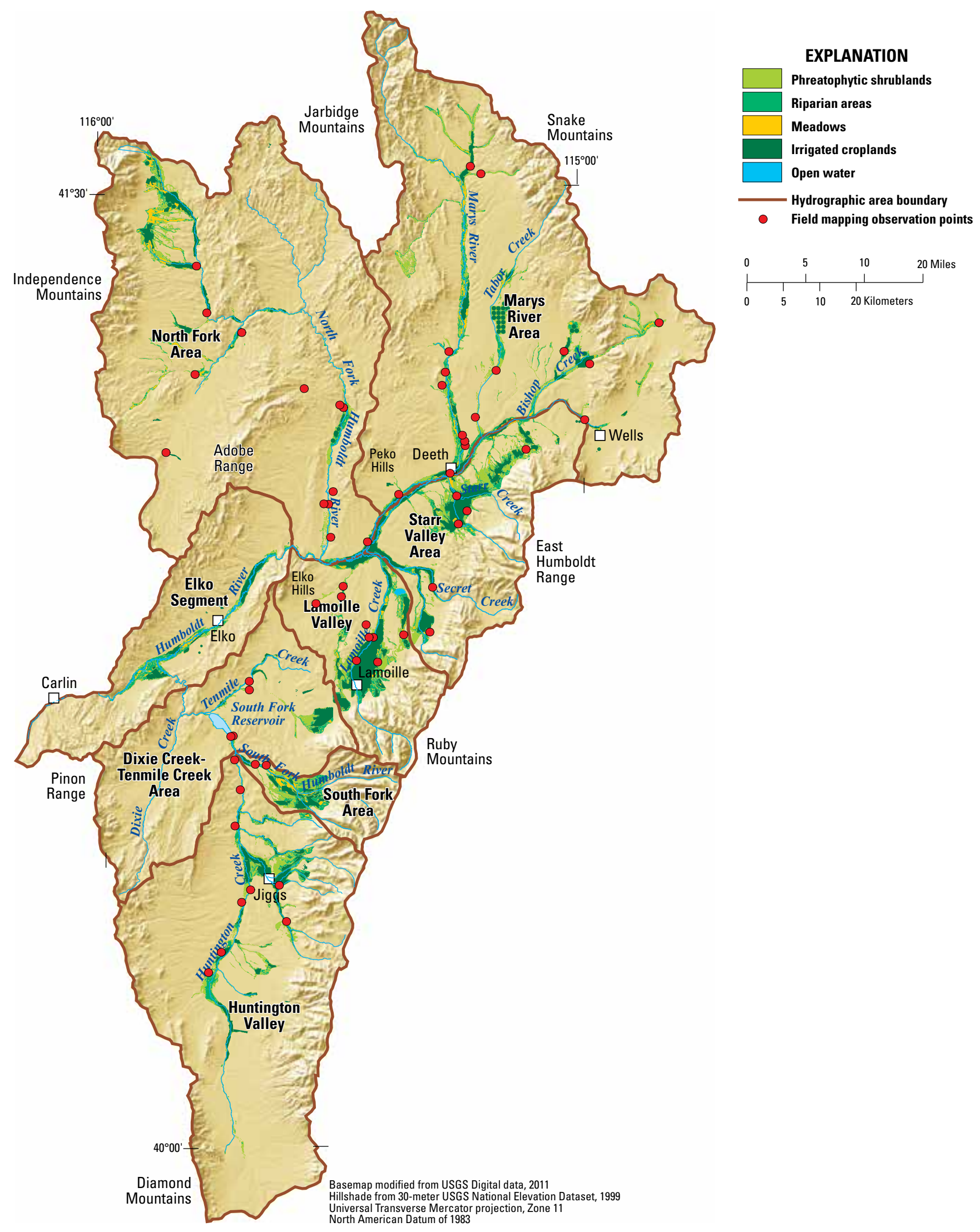

Figure 7. Discharge areas and evapotranspiration units delineated July 20-24, 2009 in the upper Humboldt River basin, northeastern Nevada. 


\section{Delineation of Discharge Areas and Evapotranspiration Units}

Discharge areas were identified and mapped in the study area (fig. 7) using techniques similar to those used by Smith and others (2007) to define potential areas of groundwater discharge in the eastern Great Basin. Areas outside of the discharge areas (non-discharge areas) are discussed later.

Discharge areas were iteratively delineated using remote sensing methods and field verification during July 20-24, 2009 (fig. 7). A combination of Landsat imagery, high-resolution imagery from the National Agricultural Imagery Program (NAIP), and a digital-elevation model were used to initially identify discharge areas. Field mapping and verification at 59 locations were used to fine tune adjustments of the remote sensing methodology to properly and more accurately identify the discharge areas. See Smith and others (2007) for a detailed discussion of this method.

The discharge areas were further classified into five individual ET units: phreatophytic shrublands, riparian areas, meadows, irrigated croplands, and open water (fig. 7). This was done by using a combination of methods depending on the ET unit being delineated.

A Modified-Soil Adjusted Vegetation Index (MSAVI) was computed from Landsat imagery (Qi and others, 1994) and was used to identify areas of phreatophytic shrublands, meadows, and riparian ET units and areas of xerophytic vegetation in discharge areas (July 11, 2008, standardized Landsat Thematic Mapper [TM] data). Areas of xerophytic vegetation were removed from the discharge areas because they are areas of no discharge.

Phreatophytic shrubland, meadow, and riparian ET units were identified by computing and classifying MSAVI from Landsat images of June 9, July 11, and September 13, 2008. These three images span the optimum period for delineating ET units responsible for $E T_{\mathrm{g}}$ during the summer while minimizing the effects and influences of vegetation that rely on precipitation for their greenness (such as spring grasses and sagebrush).

A vegetation index is a number that is generated by a combination of the visible red and near-infrared remote sensing bands and thus has some relation to the vegetation in a given image pixel. Vegetation indexes have been used to quantify the abundance and vigor of vegetation imaged by multispectral sensors (U.S. Geological Survey EROS Data Center, 2006). The MSAVI (Qi and others, 1994) removes soil influences from the vegetation index, which makes this index more applicable to areas of sparse vegetation densities than other, similar vegetation indices (for example: Normalized Difference Vegetation Index, Rouse and others, 1973; and Enhanced Vegetation Index, Huete and others, 2002). Thus, the MSAVI is an appropriate index to use to map changes in the sparse plant cover in the Nevada desert landscape. MSAVI values are dimensionless and range from -1 to 1.0 .

The use of a vegetation index to map vegetation cover is based on the assumption that the greener, denser, and more vigorous the vegetation, the greater the vegetation index. Nichols (2000) observed that in some areas of phreatophytes in the Great Basin, medium and short shrubs generally are the dominant vegetation type where plant cover is less than about 35 percent, and grasses, tall shrubs, and trees dominate where plant cover is greater than 35 percent. Xerophytic areas are those where plant cover is less than about 7 percent and bare soil is common. The ET units were iteratively determined by using field reconnaissance photographs and high-resolution imagery to identify the ranges in MSAVI that adequately segregated vegetation characteristics into units that could be readily described as in table 5 . The initial MSAVI ranges and ET unit descriptions used in this iterative process were taken from Smith and others (2007). The MSAVI ranges were adjusted until discharge areas were effectively and consistently subdivided into areas of open water, xerophytes, phreatophytic shrublands, riparian areas, meadows, and irrigated croplands. For instance, values of MSAVI were repeatedly adjusted until areas of open water produced by the data analysis matched obvious areas of open water such as the South Fork Reservoir and the reservoir in Lamoille Valley. MSAVI values used to distinguish ET units in discharge areas were: (1) less than 0.025 for open water; (2) between 0.025 and less than 0.115 for xerophytes; (3) between 0.115 and less than 0.165 for phreatophytic shrublands; (4) between 0.165 and less than 0.315 for riparian areas; and (5) 0.315 or greater for meadows or recently irrigated crops.

Irrigated acreage was manually delineated as circular and rectangular polygons from the Landsat TM images. Each of the imagery band combinations was used during the delineation process. For example, riparian vegetation and field runoff may be inseparable from irrigated croplands based solely on the natural color composite but may be identified based on the false-color infrared composite. Recently harvested fields also may not show the spectral characteristics typically associated with an irrigated field in the false color composite but may be clearly defined using a vegetation index. Supplemental geographic information system (GIS) data sets were used to aid in the delineation process. For this study, the NAIP imagery was used as secondary guides in the delineation process.

Figure 7 shows the distribution of discharge areas and ET units in the upper Humboldt River basin. All ET units, except recently irrigated cropland were filtered based on a minimum mapping unit, which was set at four adjacent pixels, an area of about 0.9 acre in the source imagery. An area this size was found to provide sufficient resolution within the source areas of similar land ET stations in a study by Moreo and others (2007). If an ET unit encompassed less than 0.9 acre, it was replaced with the value of the ET unit that was closest to it. The acreage for each ET unit and total acreages by hydrographic area are listed in table 6 and shown on figure 8 as percentages of the total discharge area. The irrigated crop ET unit is the largest of the ET units with 78,461 acres and accounts for about 33 percent of the discharge area. The phreatophytic shrubland ET unit has the next largest area with 74,933 acres, accounts for about 31 percent of the discharge area, and is 
Table 5. Evapotranspiration units delineated within discharge areas, upper Humboldt River basin, northeastern Nevada.

[See figure 7 for locations of evapotranspiration units. Abbreviations: ET, evapotranspiration; MSAVI, Modified Soil-Adjusted Vegetation Index; ft, feet; TM, Thematic Mapper; NAIP, National Agricultural Imagery Program; ft/yr, feet per year; $\mathrm{P}_{\mathrm{t}}$; total annual precipitation from fig. 6; $E T_{\mathrm{t}}$, total $\mathrm{ET}$ - difference between $E T_{\mathrm{t}}$ and $\mathrm{P}_{\mathrm{t}}$ is net $E T\left(E T_{\mathrm{n}}\right) ; E T_{\mathrm{g}}$, groundwater $E T$ - includes $E T_{\mathrm{t}}$ in phreatophytic shrublands, riparian, and meadows; $E T_{\mathrm{ag}}, E T$ of soil moisture originating from precipitation and applied irrigation water- $E T_{\mathrm{ag}}$ minus $\mathrm{P}$ is net irrigation water requirement (NIWR); $E T_{\text {w }}$, evaporation from open water]

\begin{tabular}{ll}
\hline \multicolumn{1}{c|}{ ET unit name } & \multicolumn{1}{c}{ ET unit description } \\
\hline $\begin{array}{l}\text { Phreatophytic shrub- } \\
\text { lands }\end{array}$ & $\begin{array}{l}\text { Area is characterized by sparse to moderately dense desert shrubs in open desert with dry } \\
\text { sandy soil. Shrubs mainly include greasewood, rabbitbrush, and saltbush. Has MSAVI rang- } \\
\text { ing from } 0.115 \text { to } 0.165 . \text { Depth to water can range from about } 10 \text { to } 50 \mathrm{ft} \text {. Vegetation mainly } \\
\text { relies on soil moisture originating from precipitation, but can occasionally use ground } \\
\text { water when soil moisture from precipitation is not adequate and depth to water is within the } \\
\text { plant's root system. Unit primarily occupies outer parts of discharge areas. } E T_{\mathrm{t}} \text { rate } 1.1 \mathrm{ft} / \mathrm{yr} .\end{array}$ \\
& \\
&
\end{tabular}

Riparian areas

Area is characterized by cottonwood trees, shrubs such as willows, and marsh vegetation such as rushes and reeds. Has MSAVI ranging from 0.165 to 0.315 . Depth to water can range from about 5 to $20 \mathrm{ft}$. Vegetation uses soil moisture originating from precipitation and groundwater, part of which comes from streamflow losses. Unit primarily occupies areas along stream channels. $E T_{\mathrm{t}}$ rate $4.1 \mathrm{ft} / \mathrm{yr}$.

\begin{abstract}
Meadows
Area is characterized by a dense mixture of phreatophytic shrubs, some saltcedar and mod-

erate to dense understory of saltgrass. Has MSAVI greater than 0.315 . Depth to water can
range from a few feet to $10 \mathrm{ft}$. Vegetation uses soil moisture originating from precipitation
and groundwater. This unit primarily occupies areas between riparian areas and phreato-

erate to dense understory of saltgrass. Has MSAVI greater than 0.315 . Depth to water can
range from a few feet to $10 \mathrm{ft}$. Vegetation uses soil moisture originating from precipitation
and groundwater. This unit primarily occupies areas between riparian areas and phreato-

erate to dense understory of saltgrass. Has MSAVI greater than 0.315 . Depth to water can
range from a few feet to $10 \mathrm{ft}$. Vegetation uses soil moisture originating from precipitation
and groundwater. This unit primarily occupies areas between riparian areas and phreato-

phytic shrublands or recently irrigated croplands. $E T_{\mathrm{t}}$ rate $2.6 \mathrm{ft} / \mathrm{yr}$
\end{abstract}
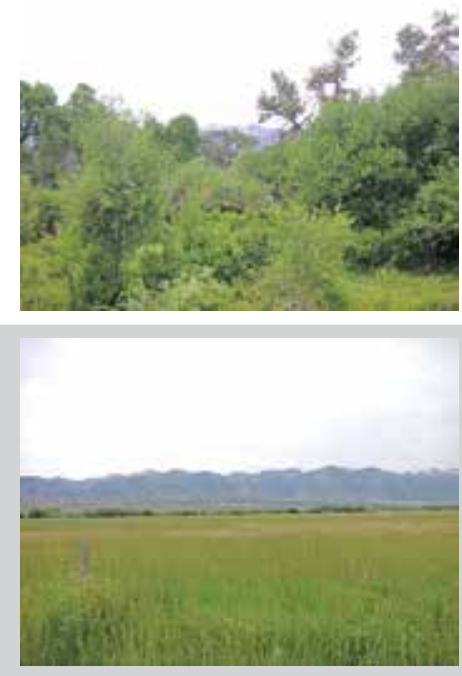

Irrigated croplands

Area dominated by irrigated cropland. Soil moisture varies with irrigation practice, but typically alternates from very moist to semi-dry during growing season. Irrigated cropland areas were determined from photographic interpretation of Landsat TM and NAIP imagery. Depth to water typically is greater than $5 \mathrm{ft}$. Vegetation uses soil moisture originating from irrigation. $E T_{\mathrm{ag}}$ rate, based on net irrigation water requirement, varies from 2.2 to $2.8 \mathrm{ft} / \mathrm{yr}$ depending on location in study area. See text and table 6 for NIWR rates.

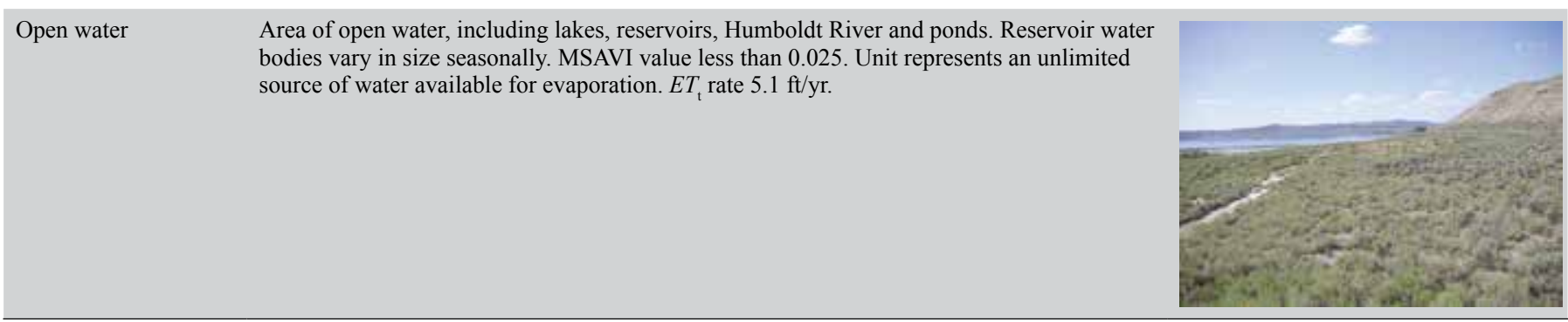


dispersed fairly evenly throughout the study area. The riparian ET unit has an area of 63,885 acres, accounts for about 27 percent of the discharge area, and mainly occurs adjacent to streams and springs and along the Humboldt River flood plain. The meadow ET unit has an area of 21,400 acres and accounts for about 9 percent of the discharge area. The open-water ET unit occupies an area of 2,279 acres and accounts for less than 1 percent of the discharge area.

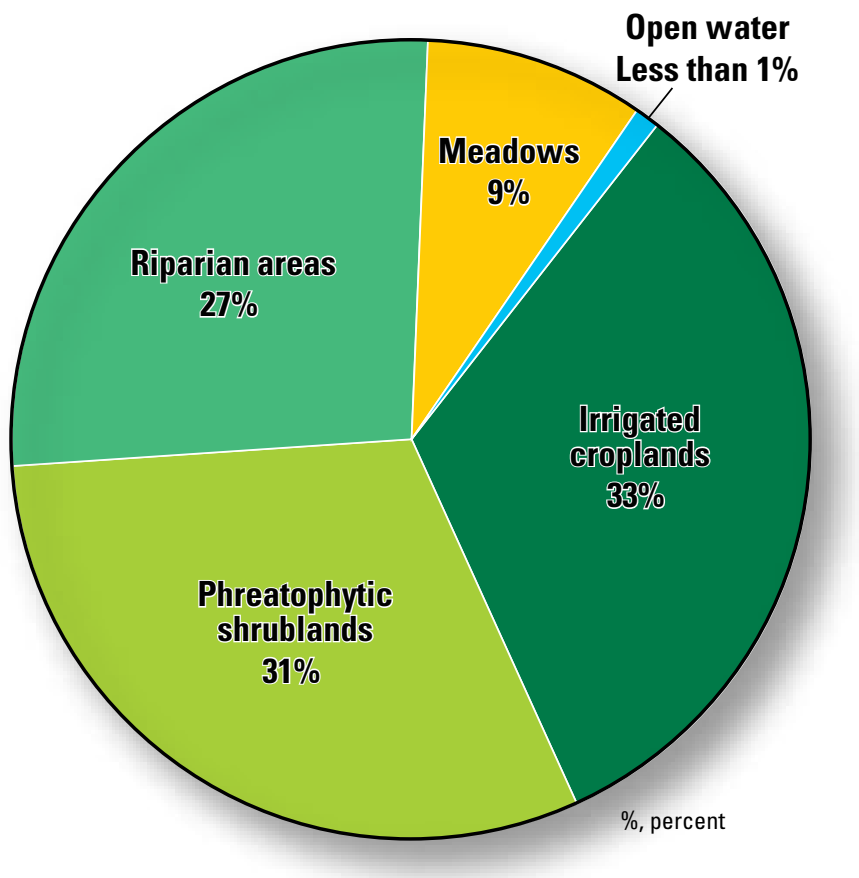

Figure 8. Distribution of evapotranspiration by evapotranspiration unit, as a percentage of total discharge area, upper Humboldt River basin, northeastern Nevada.

\section{Net Evapotranspiration and Net Irrigation Water Requirement Rates}

Net ET rates used for ET units in the upper Humboldt River basin were those used for a hydrologic study in eastern Nevada (Welch and others, 2007, appendix a). ${ }^{3}$ Net ET rates used for the upper Humboldt River basin are: phreatophytic shrublands, $0.3 \mathrm{ft} / \mathrm{yr}$; riparian areas, $3.3 \mathrm{ft} / \mathrm{yr}$; meadows,

$1.7 \mathrm{ft} / \mathrm{yr}$; and open water, $4.3 \mathrm{ft} / \mathrm{yr}$.

The net irrigation water requirement (NIWR) of an irrigated crop is the rate at which water must be applied for the crop to grow and remain healthy. The NIWR of a crop is equivalent to the net ET rate for other ET units in that both rates equal a total rate minus the annual precipitation. Values of NIWR for crops in each hydrographic area in Nevada are presented at the NDWR website at http://water.nv.gov/mapping/et/et_general. $c f m$. NIWR rates for alfalfa and highly managed pasture grass are $2.4 \mathrm{ft} / \mathrm{yr}$ for the Marys River Area, $2.4 \mathrm{ft} / \mathrm{yr}$ for the Starr Valley Area, $2.2 \mathrm{ft} / \mathrm{yr}$ for the North Fork Area, $2.3 \mathrm{ft} / \mathrm{yr}$ for Lamoille Valley, $2.5 \mathrm{ft} / \mathrm{yr}$ for the South Fork Area, $2.4 \mathrm{ft} / \mathrm{yr}$ for Huntington Valley, $2.8 \mathrm{ft} / \mathrm{yr}$ for the Dixie Creek-Tenmile Creek Area, and $2.6 \mathrm{ft} / \mathrm{yr}$ for the Elko Segment.

\footnotetext{
${ }^{3}$ This appendix is a spreadsheet that can be found at http://pubs.usgs.gov/ sir/2007/5261/. The discharge-rate tab in the spreadsheet lists net ET rates for ET units at 26 sites in 12 basins in eastern Nevada. Net ET rates used for the upper Humboldt River basin are averages determined from the spreadsheet. ET units in the upper Humboldt River basin correspond with similar units in eastern Nevada as follows: phreatophytic shrublands in the upper Humboldt River basin correspond with moderately dense desert shrubland in eastern Nevada; riparian areas with marshland; meadows with meadowlands; and open water with open water.
}

Table 6. Areas of evapotranspiration units and volumes of net evapotranspiration $\left(E T_{\mathrm{n}}\right)$ in discharge areas by hydrographic area in the upper Humboldt River basin, northeastern Nevada.

[See table 5 and figure 7 for ET unit descriptions and locations. Abbreviations: ET, evapotranspiration; acre-ft/yr, acre feet per year; ft/yr, feet per year]

\begin{tabular}{|c|c|c|c|c|c|c|c|c|c|c|c|c|}
\hline \multirow{2}{*}{ Hydrographic area } & \multicolumn{2}{|c|}{$\begin{array}{l}\text { Phreatophytic } \\
\text { shrublands }\end{array}$} & \multicolumn{2}{|c|}{ Riparian areas } & \multicolumn{2}{|c|}{ Meadows } & \multicolumn{2}{|c|}{ Irrigated croplands } & \multicolumn{2}{|c|}{ Open water } & \multicolumn{2}{|c|}{ Totals } \\
\hline & $\begin{array}{c}\text { Area } \\
\text { (acres) }\end{array}$ & $\begin{array}{c}\text { Volume }^{1} \\
\text { (acre-ft/yr) }\end{array}$ & $\begin{array}{c}\text { Area } \\
\text { (acres) }\end{array}$ & $\begin{array}{l}\text { Volume }^{1} \\
\text { (acre-ft/yr) }\end{array}$ & $\begin{array}{c}\text { Area } \\
\text { (acres) }\end{array}$ & $\begin{array}{l}\text { Volume }^{1} \\
\text { (acre-ft/yr) }\end{array}$ & $\begin{array}{c}\text { Area } \\
\text { (acres) }\end{array}$ & $\begin{array}{l}\text { Volume }^{2} \\
\text { (acre-ft/yr) }\end{array}$ & $\begin{array}{c}\text { Area } \\
\text { (acres) }\end{array}$ & $\begin{array}{l}\text { Volume }^{1} \\
\text { (acre-ft/yr) }\end{array}$ & $\begin{array}{c}\text { Area } \\
\text { (acres) }\end{array}$ & $\begin{array}{c}\text { Volume } \\
\text { (acre-ft/yr) }\end{array}$ \\
\hline Marys River & 19,376 & 5,810 & 17,091 & 56,400 & 6,607 & 11,232 & 10,804 & 25,900 & 109 & 470 & 53,987 & 99,800 \\
\hline Starr Valley & 13,164 & 3,950 & 10,430 & 34,400 & 2,766 & 4,702 & 17,976 & 43,100 & 3 & 13 & 44,339 & 86,200 \\
\hline North Fork & 11,302 & 3,390 & 9,251 & 30,500 & 5,266 & 8,952 & 10,118 & 22,300 & 116 & 500 & 36,053 & 65,600 \\
\hline Lamoille Valley & 8,685 & 2,610 & 7,537 & 24,900 & 1,998 & 3,397 & 16,450 & 37,800 & 436 & 1,870 & 35,106 & 70,600 \\
\hline South Fork & 4,357 & 1,310 & 4,143 & 13,700 & 2,107 & 3,582 & 4,383 & 11,000 & 1 & 4 & 14,991 & 29,600 \\
\hline Huntington Valley & 12,343 & 3,700 & 8,544 & 28,200 & 1,174 & 1,996 & 11,172 & 26,800 & 12 & 52 & 33,245 & 60,700 \\
\hline Dixie Creek-Tenmile Creek & 3,073 & 920 & 1,809 & 5,970 & 230 & 391 & 3,488 & 9,770 & 1,481 & 6,370 & 10,081 & 23,400 \\
\hline Elko Segment & 2,633 & 790 & 5,080 & 16,800 & 1,252 & 2,128 & 4,070 & 10,600 & 121 & 520 & 13,156 & 30,800 \\
\hline Totals & 74,933 & 22,500 & 63,885 & 211,000 & 21,400 & 36,400 & 78,461 & 187,000 & 2,279 & 9,800 & 240,958 & 467,000 \\
\hline
\end{tabular}

${ }^{1}$ Volumes of net $E T(E T)$, in acre-feet per year, calculated as product of $E T$ unit area and net $E T$ rate for each unit (fig. 7). Net $E T$ rates, in feet per year as follows: $0.3 \mathrm{ft} / \mathrm{yr}$ for phreatophytic shrublands, $3.3 \mathrm{ft} / \mathrm{yr}$ for riparian areas, $1.7 \mathrm{ft} / \mathrm{yr}$ for meadows, and $4.3 \mathrm{ft} / \mathrm{yr}$ for open water.

${ }^{2}$ Volumes of $E T$ from irrigated crops ( $E T_{\mathrm{ag}}$ ), in acre-feet per year, calculated as product of crop area and net irrigation water requirement (NIWR) of crop. Values of NIWR are listed for each hydrographic area in the upper Humboldt River basin range on the Nevada Division of Water Resources website at http://water.nv.gov/mapping/et/et_general.cfm. Alfalfa and highly managed pasture grass are believed to be most common crops in the upper Humboldt River basin. Average values of NIWR for these two crops, in feet per year, are: $2.4 \mathrm{ft} / \mathrm{yr}-$ Marys River, $2.4 \mathrm{ft} / \mathrm{yr}-\mathrm{Starr}$ Valley, $2.2 \mathrm{ft} / \mathrm{yr}$-North Fork, $2.3 \mathrm{ft} / \mathrm{yr}$-Lamoille Valley, $2.5 \mathrm{ft} / \mathrm{yr}$-South Fork, $2.4 \mathrm{ft} / \mathrm{yr}-\mathrm{Huntington}$ Valley, $2.8 \mathrm{ft} / \mathrm{yr}-\mathrm{Dixie} \mathrm{Creek}-\mathrm{Tenmile}$ Creek, and $2.6 \mathrm{ft} / \mathrm{yr}-$ Elko Segment. 


\section{Net Evapotranspiration Discharge}

Volumes of net evapotranspiration $\left(E T_{\mathrm{n}}\right)$, in acre-feet per year, for each hydrographic area in the upper Humboldt River basin (table 6) were computed as the sum of the products of the area, in acres, of each ET unit and its appropriate net ET rate or NIWR, in feet per year. Total volumes of $E T_{\mathrm{n}}$ from the five ET units shown in table 6 range from 9,800 acre-ft/yr for the open water ET unit to 211,000 acre-ft/yr for riparian areas. Volumes of $E T_{n}$ from the eight hydrographic areas in the upper Humboldt River basin range from 23,400 acre-ft/yr in the Dixie Creek-Tenmile Creek Area to 99,800 acre-ft/y in the Marys River Area. Total net evapotranspiration from discharge areas in the upper Humboldt River basin is 467,000 acre- $\mathrm{ft} / \mathrm{yr}$. As mentioned earlier, the proportions of groundwater and surface water that contribute to this total cannot be determined.

Volumes of net ET discussed above and listed in table 6 are uncertain for reasons that include the accuracy of the field mapping of the ET units and the net ET rates that were used. Generally, the outer boundary of discharge areas and of ET units could be clearly distinguished from the imagery used for the mapping. However, some areas of phreatophytic shrubs were mixed with other desert shrubs or were very sparse, especially along outer fringes and here the boundary of the discharge area was more difficult to define. The outer boundary of phreatophytic shrubs generally occurs at or near the same altitude in a given area due to similar depths to groundwater. Where this boundary was not easily defined on the basis of data from the field mapped points and NAIP imagery, the boundary was estimated using equal altitude contours from a digital elevation model.

The net ET rates used to compute net volumes of ET were developed in parts of east-central Nevada that are as much as $200 \mathrm{mi}$ south of the upper Humboldt River basin. The net ET rate, in feet per year, at any site is assumed to be the local difference between total ET and total annual precipitation. Annual precipitation in the upper Humboldt River basin generally is greater than in areas of Nevada farther south, and for this reason the net ET rates used for the present study may not be as accurate as if ET rates were directly measured in the study area. Measurement of ET rates at strategically located micrometeorological stations in the upper Humboldt River basin would reduce this uncertainty.

Several basins in east-central Nevada have extensive discharge areas including open water, marshes, and meadows (Welch and others, 2007, fig. 34), and for this reason are similar to the discharge areas in the upper Humboldt River basin. Statistical analysis of the uncertainties of net discharge volumes for these basins produced uncertainties of about 25 percent. It is assumed that this is the approximate uncertainty of estimates of net ET for the upper Humboldt River basin.

\section{Evapotranspiration of Precipitation}

ET of precipitation $\left(E T_{\mathrm{p}}\right)$ is the second largest water-budget component in the upper Humboldt River basin. It is exceeded only by total precipitation $\left(P_{t}\right)$ and it exceeds all other outflow components combined. $E T_{\mathrm{p}}$ occurs in both discharge areas and in non-discharge areas. In discharge areas, $E T_{\mathrm{p}}$ is assumed to be equal to $P_{\mathrm{t}}$. In non-discharge areas, $E T_{\mathrm{p}}$ is less than or equal to $P_{\mathrm{t}}$ and represents $E T_{\mathrm{t}}$. Any differences between $E T_{\mathrm{p}}$ and $P_{\mathrm{t}}$ are due to runoff of precipitation or infiltration of precipitation to the water table. Direct estimation of $E T_{\mathrm{p}}$ for this study was not possible because ET rates in non-discharge areas are so variable. Therefore $E T_{\mathrm{p}}$ is estimated as the residual of the water budget equation (equation 2) and as a result all errors and uncertainties in the outflow terms in equation 2 are incorporated in this single term.

\section{Surface-Water Outflow}

All surface-water outflow from the upper Humboldt River basin is recorded at the Humboldt River near Carlin gaging station (USGS site identification number 10321000). This station has been in continuous operation since 1944 and the mean annual flow for the 65 -year period of record is 266,000 acre-ft/yr (fig. 9). The mean annual flow for the 30 -year period $1971-2000$ is 316,000 acre- $\mathrm{ft} / \mathrm{yr}$ and this is the value used for the total water budget.

Flow of the Humboldt River at this site has ranged from about 46,000 acre-feet (acre-ft) in 1959 to 1,250,000 acre-ft in 1984. Years of above average runoff result from a combination of warm winter storms and high- and low-altitude snowmelt. Years of below-average runoff originate mostly from sparse high-altitude snowmelt. From 1945 through 1980, the duration of periods of above-average runoff was 1 to 3 years and the duration of periods of below-average runoff was 3 to 4 years. Since 1980 three droughts of 4, 5, and 8 years duration have resulted in extended periods of below-average runoff. However, above-average runoff in 1983-84, 1995-98, and 2005-06 more than compensated for below-average flows in other years and as a result, the 1971-2000 average annual flow exceeds the long-term average by 50,000 acre-ft/yr. The record at the Carlin gaging station is generally rated as fair, which means that the uncertainty of annual volumes of flow shown in figure 9 is 15 percent (Allander and others, 2001, p. 21 and 208).

\section{Subsurface Flow}

Subsurface flow is a minor outflow component of the upper Humboldt River basin water budget. However, it can be used to estimate subsurface flow between hydrographic areas and thus provide minimum estimates of groundwater recharge and discharge between hydrographic areas. Subsurface flow is estimated using equation 1 . The transmissivity of the aquifer, its effective width, and the gradient driving groundwater flow are the three variables used in the equation. Locations of subsurface flow sections are shown on figure 10 and aquifer properties and estimates of subsurface flow are listed in table 7. 


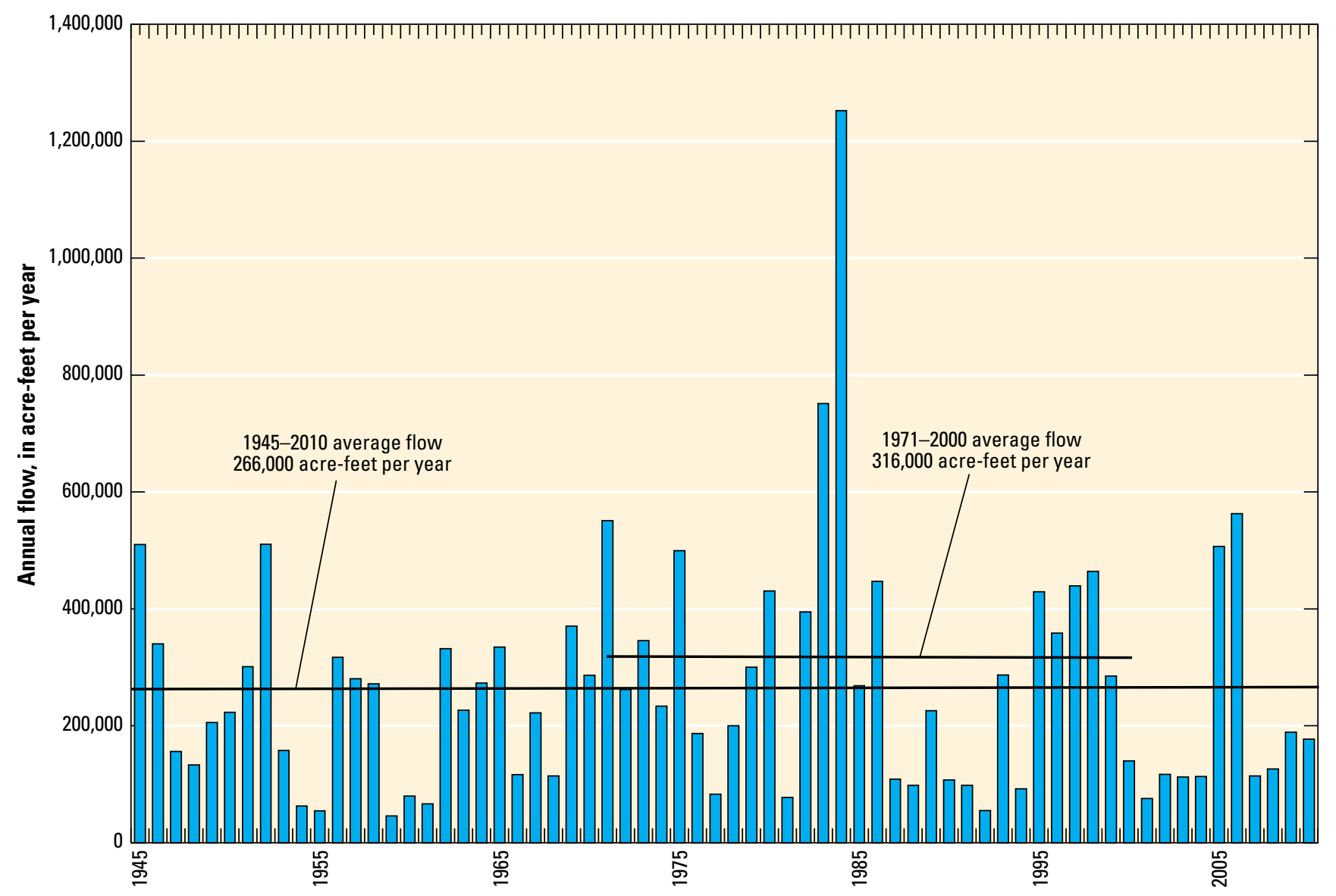

Figure 9. Annual flow of the Humboldt River near Carlin, 1945-2010, northeastern Nevada.

Sections are located at the downgradient ends of the Marys River Area (section $\left.A-A^{\prime}\right)$, Starr Valley Area $\left(B-B^{\prime}\right)$, North Fork Area $\left(C-C^{\prime}\right)$, Lamoille Valley $\left(D-D^{\prime}\right)$, Huntington Valley $\left(E-E^{\prime}\right)$, and Dixie Creek-Tenmile Creek Area $\left(F-F^{\prime}\right)$. Subsurface flow ranges from about $400 \mathrm{acre}-\mathrm{ft} / \mathrm{yr}$ at the north end of Huntington Valley to 3,000 acre-ft/yr in the Starr Valley and

Table 7. Estimates of subsurface flow at eight aquifer cross sections in the upper Humboldt River basin, northeastern Nevada.

\begin{tabular}{|c|c|c|c|c|c|}
\hline Hydrographic area & Section ${ }^{1}$ & $\begin{array}{c}\text { Mean } \\
\text { transmissivity } \\
\text { (feet squared } \\
\text { per day) }\end{array}$ & Gradient $^{3}$ & $\begin{array}{l}\text { Cross section } \\
\text { width' }^{1} \\
\text { (miles) }\end{array}$ & $\begin{array}{c}\text { Annual } \\
\text { subsurface flow } \\
\text { (acre-feet/year) }\end{array}$ \\
\hline Marys River & $\mathrm{A}-\mathrm{A}^{\prime}$ & 700 & 0.004 & 18 & 2,000 \\
\hline Starr Valley & $\mathrm{B}-\mathrm{B}^{\prime}$ & 300 & 0.013 & 20 & 3,000 \\
\hline North Fork & $\mathrm{C}-\mathrm{C}^{\prime}$ & 500 & 0.003 & 10.4 & 700 \\
\hline Lamoille Valley & D-D' & 900 & 0.003 & 11 & 1,000 \\
\hline Huntington Valley & $E-E^{\prime}$ & 600 & 0.002 & 7 & 400 \\
\hline Dixie Creek-Tenmile Creek & $\mathrm{F}-\mathrm{F}^{\prime}$ & 900 & 0.006 & 13 & 3,000 \\
\hline Elko Segment & $\mathrm{G}-\mathrm{G}^{\prime}$ & 700 & 0.001 & 4.4 & 100 \\
\hline Southern Ruby Mountains & $\mathrm{H}-\mathrm{H}^{\prime}$ & 5,000 & 0.001 & 20 & 4,000 \\
\hline
\end{tabular}

Dixie Creek-Tenmile Creek Areas. Subsurface outflow from the upper Humboldt River basin at the southwest end of the Elko Segment (section $G-G$ ', fig. 10 and table 7) is estimated to be about 100 acre-ft/yr through Humboldt River flood plain deposits and adjacent basin-fill deposits.

Groundwater also leaves the upper Humboldt River basin in the southern Ruby Mountains (flow section $H-H^{\prime}$, fig. 10). The relatively high permeability of the carbonate rocks in the southern Ruby Mountains is indicated by the absence of perennial streams (fig. 1). This, combined with the eastward dip of the rocks, probably results in eastward groundwater flow from the west side of the Ruby Mountains to Ruby Valley east of the study area (Rush and Everett, 1966, p. 15; and Dudley, 1967, p. 88-98). Rush and Everett (1966, p. 15) estimated subsurface outflow to Ruby Valley at 10,000 acre-ft/yr and Dudley (1967, p. 97) found that the groundwater divide between Huntington and 


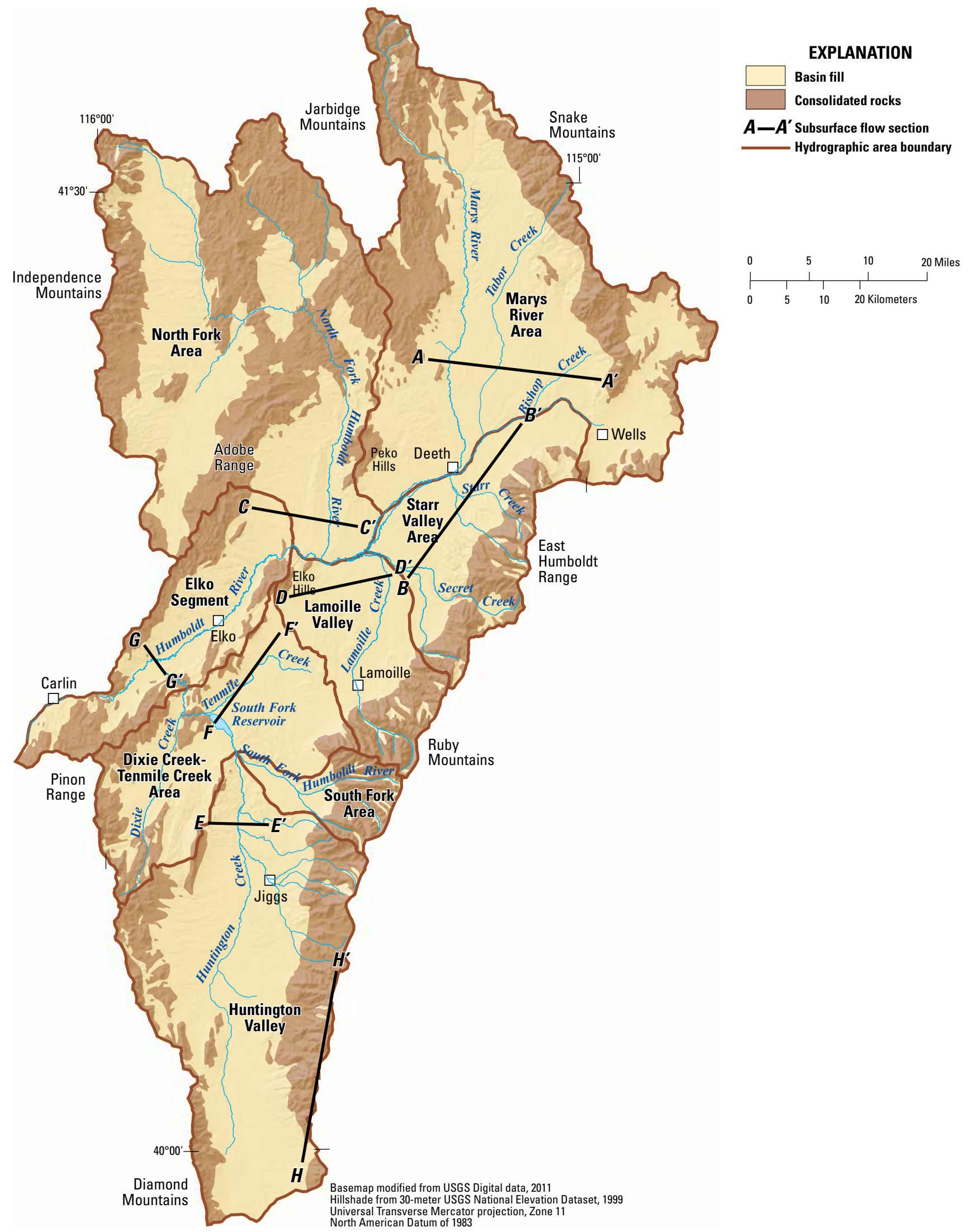

Figure 10. Locations of subsurface flow sections, upper Humboldt River basin, northeastern Nevada. 
Ruby Valleys may be as much as 2 mi west of the topographic divide between the two valleys. Total subsurface flow through the southern Ruby Mountains is estimated to be about 4,000 acre- $\mathrm{ft} / \mathrm{yr}$ based on a transmissivity of $5,000 \mathrm{ft}^{2} / \mathrm{d}$, a flow section width of $20 \mathrm{mi}$ (fig. 11), and a gradient of 0.001 (Berger, 2006, p. 27).

The estimates of subsurface outflow from the upper Humboldt River basin, 100 and 4,000 acre-ft/yr at the southwest end of the Elko Segment and in Huntington Valley at the southern end of the Ruby Mountains, respectively, are uncertain mostly because the values of transmissivity are so uncertain. Transmissivity estimates shown on figure 5 can vary by three orders of magnitude over short distances in the upper Humboldt River basin. Fortunately, subsurface flow estimates are small and are a minor component of the upper Humboldt River basin water budget.

\section{Pumpage}

Groundwater in the upper Humboldt River basin is mainly used for municipal and domestic purposes and irrigation of crops. The population of Elko County in 1990, a little more than halfway through the 1971-2000 water-budget period, was 33,530 (http://www.census.gov/population/cencounts/ $n v 190090 . t x t$ ). As of 1999 the per capita annual water use for domestic and municipal purposes in the Humboldt River basin was an estimated 0.4 acre-ft/yr (Prudic and others, 2006, p. 11). This water-use rate probably did not change substantially during the 1971-2000 water-budget period, and estimated pumpage for domestic and municipal purposes is an estimated 13,000 acre-ft/yr. The area of irrigated croplands (alfalfa and grass) in the upper Humboldt River basin is 78,461 acres (table 6), but most of this area is irrigated with surface water, so pumping for irrigation purposes is most likely less than 10,000 acre-ft/yr. In addition, this volume of pumpage has been accounted for as ET from the irrigated croplands unit. As a result only total annual pumping for domestic and municipal uses, 13,000 acre-ft/yr, is used as the value of estimated pumpage for the water budget.
$(13,000$ acre-ft/yr). For purposes of this budget total inflow and total outflow are assumed to be equal so evapotranspiration of precipitation, 2,530,000 acre- $\mathrm{ft} / \mathrm{yr}$, is computed as the difference between total inflow and the sum of $E T_{n}$, surfacewater outflow, subsurface flow and municipal and domestic pumpage. As mentioned above $E T_{\mathrm{p}}$ is the largest and most uncertain of the outflow components and the overall budget probably has an uncertainty of 25 percent.

\section{Surface-Water-Groundwater Interactions}

Surface water and groundwater are interconnected in parts of the upper Humboldt River basin. Groundwater seepage to stream channels is the main source of streamflow during baseflow periods in late summer and fall and infiltration of streamflow is a source of groundwater recharge. Two methods were used to understand these interactions: (1) late fall seepage runs and (2) analysis of water-level records in shallow wells along the Humboldt River flood plain.

\section{Seepage Runs}

During a seepage run, flow is measured along a reach of stream at multiple sites over as short a time as possible. Changes in flow rates between pairs of sites are used to identify stream reaches that either gain flow from groundwater seepage to the stream channel, or that lose flow as infiltration to the underlying aquifer. Seepage runs typically are done during low flow conditions in late fall after irrigation diversions have ended, evapotranspiration rates have decreased to minimum values, before ice accumulates in the stream, and before winter storms have affected streamflow. In the upper Humboldt River basin, diversions of streamflow for irrigation end each year on August 15 (Malone, 1932, p. 13). When interpreting changes in flow between seepage run sites, it is important to know if flow of the stream was changing before or during

\section{Water Budget}

The water budget for the upper Humboldt River basin is shown in table 8 . Total inflow, 3,330,000 acre-ft/ yr, comes entirely from annual precipitation. Total outflow consists of $E T_{\mathrm{p}}$, which cannot be reliably estimated, $E T_{\mathrm{n}}(467,000$ acre-ft/yr), surface-water outflow (316,000 acre-ft/yr), subsurface outflow $(4,100$ acre-ft/yr), and municipal and domestic pumpage
Table 8. Annual water budget, 1971-2000, for the upper Humboldt River basin, northeastern Nevada.

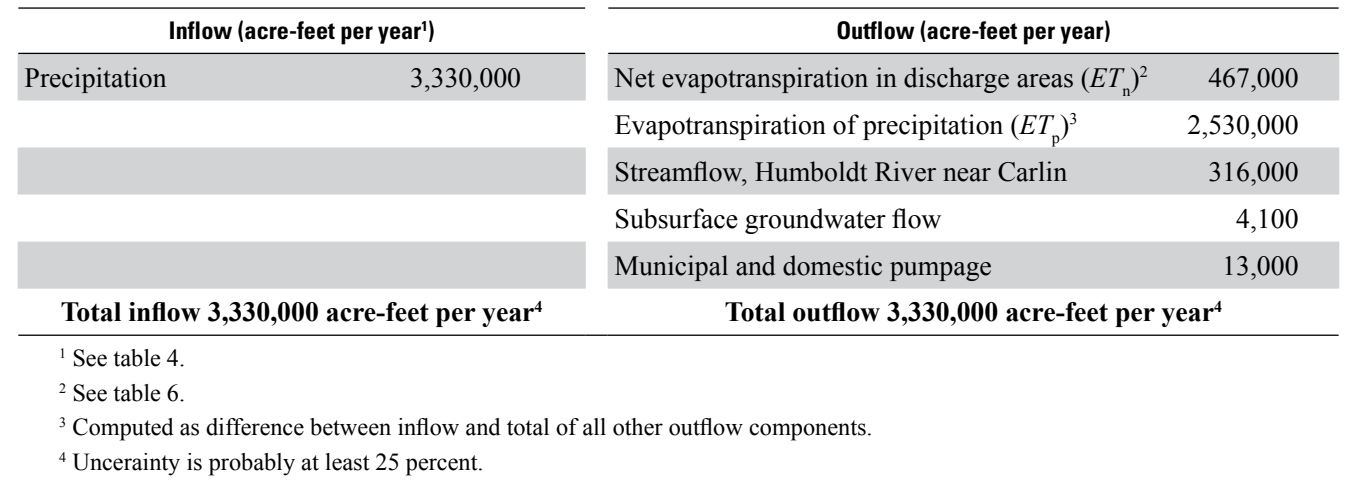


A October 2008

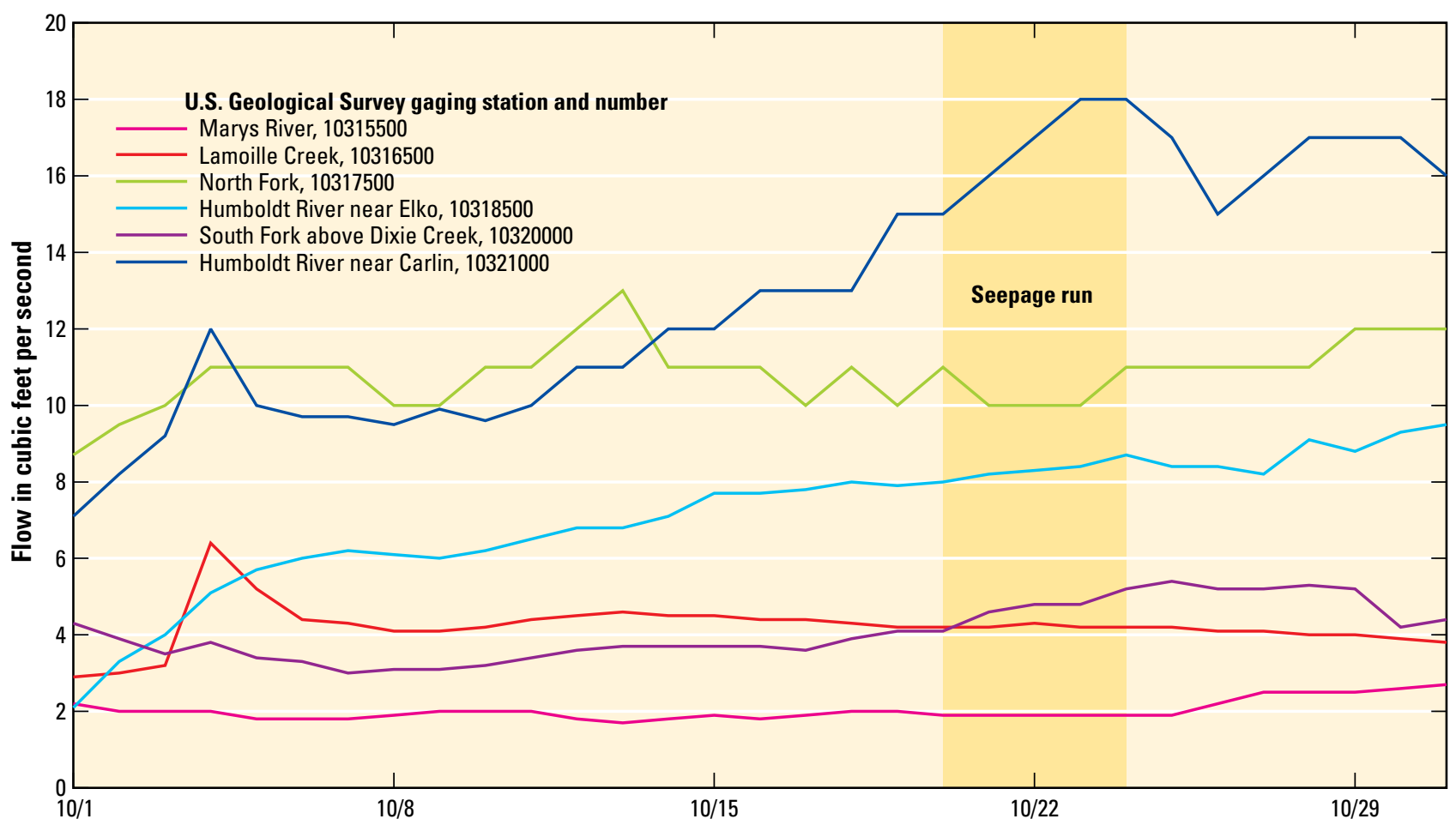

B October and early November 2009

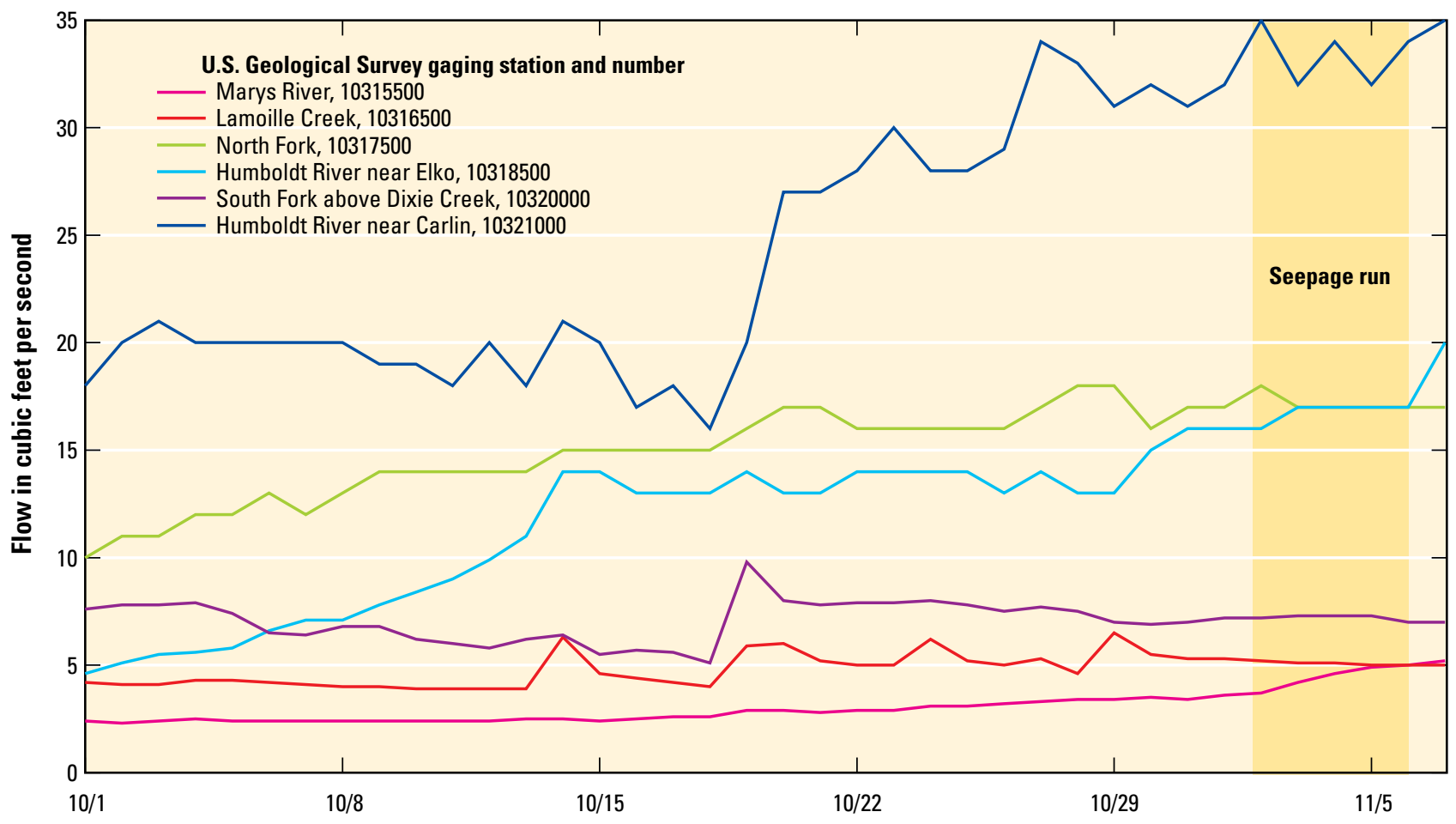

Figure 11. Streamflow conditions at six gaging stations before and during the fall seepage runs in the upper Humboldt River basin, northeastern Nevada: $A$, October 2008 and B, October and early November 2009. 
the seepage run. Figure 11 shows hydrographs recorded at six stream gaging stations - two on the mainstem Humboldt River near Elko and Carlin and four on its main tributaries. These hydrographs are used as an aid in interpreting the seepage run data.

Seepage runs were done during the weeks of October 20-24, 2008, at 88 sites and November 2-6, 2009, at 103 sites (fig. 12; appendixes 1-3). Analysis of the 2008 streamflow data was used to adjust the number and locations of sites for the 2009 run. During the two seepage runs streamflow was measured on the mainstem Humboldt River and on its tributaries. Site locations are shown on figures 12 and $13 A-18 A$. Changes in streamflow are shown as graphs of streamflow plotted against distance, in miles, downstream of the uppermost site on each stream (figs. 13B-18B). Each streamflow measurement is shown on the graphs as a vertical bar that represents its uncertainty. Nearly all of the measurements were rated as fair ( 8 percent) and this is the range shown by each bar.

\section{Marys River}

Streamflow was measured at 13 sites in the Marys River Area (fig. 13A; appendix 1). Six of the sites were on Bishop and Tabor Creeks which are tributaries of the Humboldt River, two were on $\mathrm{T}$ and Currant Creeks which are tributaries of Marys River, and five were on Marys River. The reach of Marys River between sites MR1 and MR2 lost 2.5 cubic feet per second $\left(\mathrm{ft}^{3} / \mathrm{s}\right)$ to infiltration in 2008 and gained $1.9 \mathrm{ft}^{3} / \mathrm{s}$ in 2009 , possibly in part from tributary inflow of $\mathrm{T}$ and Currant Creeks (fig. 13 and appendixes 2 and 3); however, this small gain is questionable because it is within the uncertainties of the two flow measurements used to calculate it. Flow between sites MR2 and MR3 increased by $2.0 \mathrm{ft}^{3} / \mathrm{s}$ in 2008 and decreased by $4.1 \mathrm{ft}^{3} / \mathrm{s}$ in 2009 . The reasons for a flow gain in one year and a loss in the next are not clear. In both years Marys River rapidly lost flow below site MR3; and in its lower reaches at and below site MR4, the river was dry. This is consistent with a statistical analysis of Marys River streamflow that indicates the lower reaches have no baseflow (Plume, 2009, p. 5). The hydrographs for flow of Marys River at site MR3 in figure 11 indicate that flow was not changing appreciably either before or during either of the seepage runs.

\section{Starr Valley Area}

The Starr Valley Area is drained by several small streams that are tributaries of the Humboldt River (fig. 12; appendix 1). During the 2008 and 2009 seepage runs these streams contributed only minor amounts of streamflow to the river (appendix 1). For this reason no detailed analysis of the flow of these streams is presented.

\section{North Fork Humboldt River}

Streamflow was measured at 15 sites in the North Fork Area, 7 on the North Fork Humboldt River and 8 on its tributaries (fig. 14A; appendix 1). Flow changes between sites NF1, NF2, and NF3 were minimal in both 2008 and 2009, which indicates little or no interchange of groundwater and streamflow along this reach of the North Fork Humboldt River (fig. 14B). Site NF3A is on the North Fork Humboldt River just below the mouth of Pie Creek. Streamflow at this site was not measured; the value shown on figure $14 B$ is the sum of measured flow at the mouth of Pie Creek (PC2) and in the river just above Pie Creek at site NF3. Pie Creek is an ephemeral stream in its upper reaches in the North Fork Area. However, the flow of Pie Creek increased from 6.3 to $13 \mathrm{ft}^{3} / \mathrm{s}$ in 2009 as a result of groundwater seepage to its channel along the reach that is $0.6 \mathrm{mi}$ above its mouth (fig. $14 B$ and appendix 3). The channel of Pie Creek is incised in older basin-fill deposits that, along with younger basin-fill deposits, are the principal aquifer in the upper part of the North Fork Area (Plume, 2009, pl. 1). Groundwater discharge to the channel of Pie Creek probably is the result of eastward thinning of the aquifer which is underlain by and juxtaposed against poorly permeable volcanic rocks consisting of rhyolite flows on the east side of the upper basin (Coats, 1987, pl. 1). The North Fork Humboldt River lost 1.2 and $5.7 \mathrm{ft}^{3} / \mathrm{s}$, respectively between Pie and Beaver Creeks (sites NF3a and NF4) as a result of infiltration into underlying volcanic rocks which are described as welded tuffs (Coats, 1987, pl. 1). These rocks are probably fractured and, as a result, may be fairly permeable. The North Fork Humboldt River gained 5.6 and $6.1 \mathrm{ft}^{3} / \mathrm{s}$, respectively, between sites NF4 and NF5 in 2008 and 2009. A small part of the gains were from Beaver Creek (0.7 and $1.7 \mathrm{ft}^{3} / \mathrm{s}$ in 2008 and 2009, respectively) and the rest from groundwater seepage to the North Fork channel. This reach of the river is incised into several types of volcanic rocks and older basin-fill deposits (Coats, 1987, pl. 1), and it is not known which is the source of groundwater seepage to the stream channel. The North Fork Humboldt River loses flow between sites NF5, NF6, and NF7 at its mouth as a result of infiltration to the underlying aquifer. The hydrographs for flow of the North Fork Humboldt River at site NF5 in figure 11 indicate that flow variations were about $1 \mathrm{ft}^{3} / \mathrm{s}$ just before and during both of the seepage runs. However, these fluctuations were not enough to affect interpretation of the seepage run data.

\section{Lamoille Creek}

During the two seepage runs Lamoille Creek lost flow, $4.1 \mathrm{ft}^{3} / \mathrm{s}$ in 2008 and $4.5 \mathrm{ft}^{3} / \mathrm{s}$ in 2009, between site LC1 at the mouth of Lamoille Canyon and site LC8 near the confluence with the Humboldt River (fig. 15). The flow losses occurred as a result of diversions and infiltration of streamflow into permeable deposits of glacial outwash and till. Historical records for the Elko airport weather station, available on the internet, 


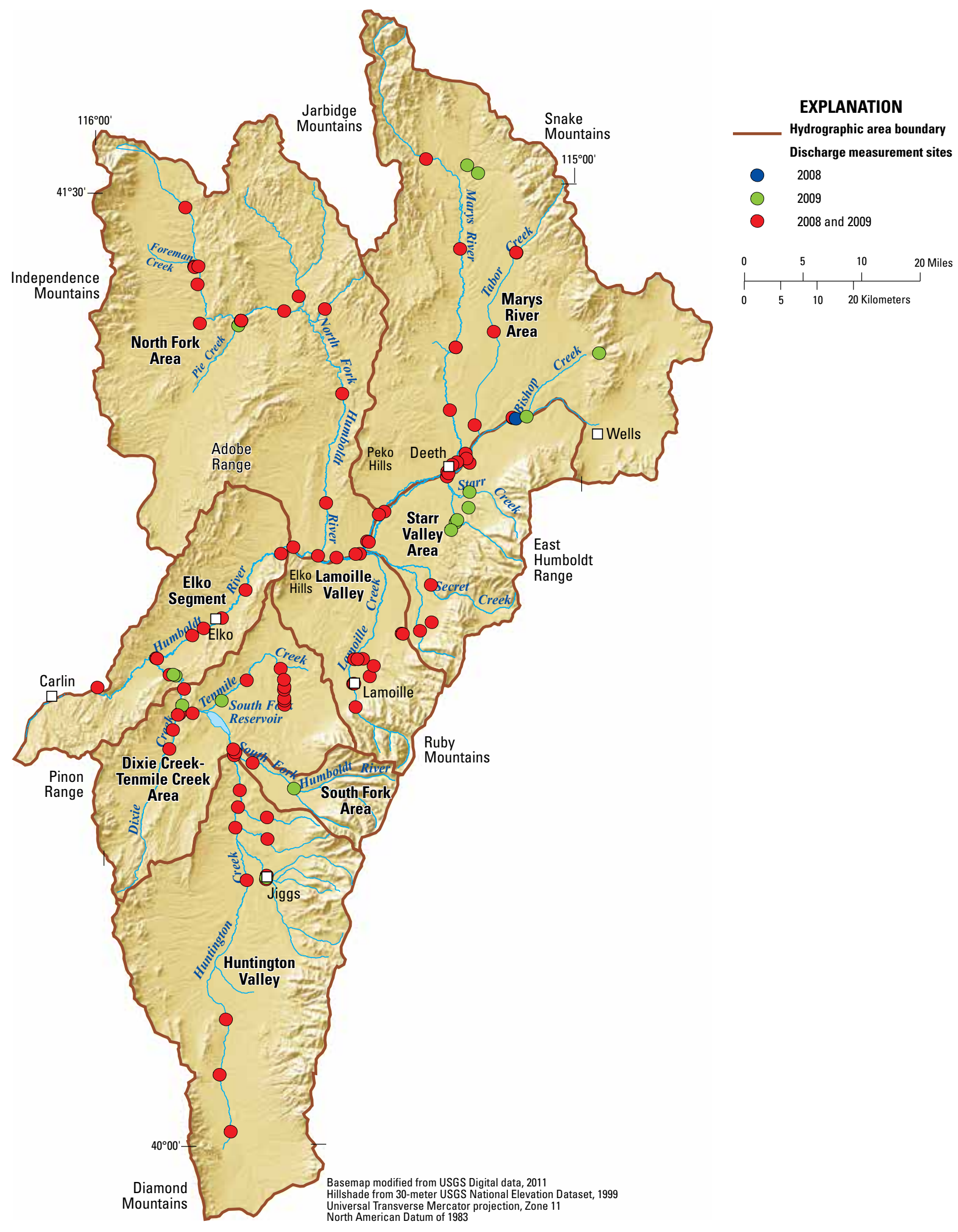

Figure 12. Locations of sites where streamflow was measured during fall seepage runs, 2008-09, upper Humboldt River basin, northeastern Nevada. 


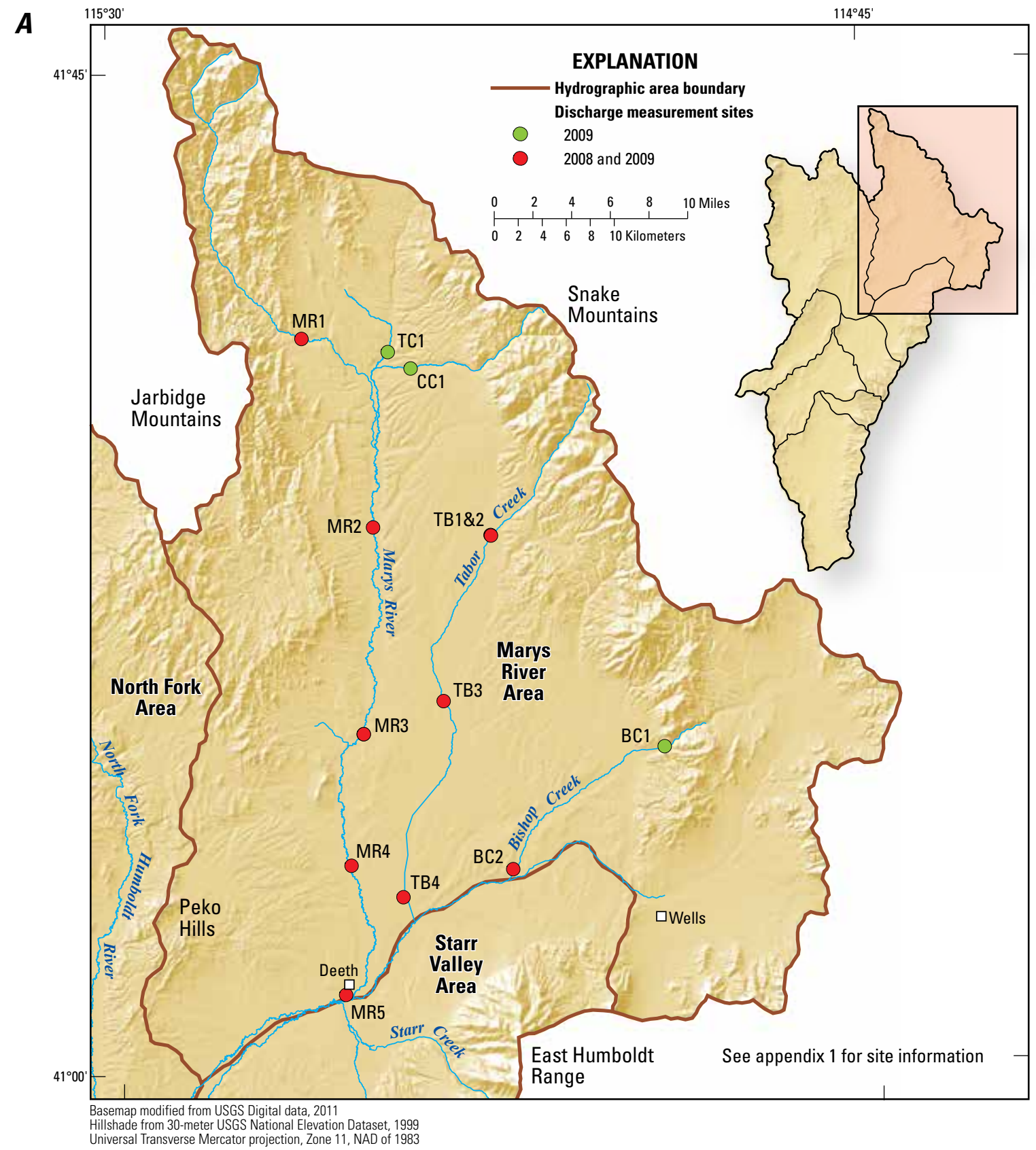

B

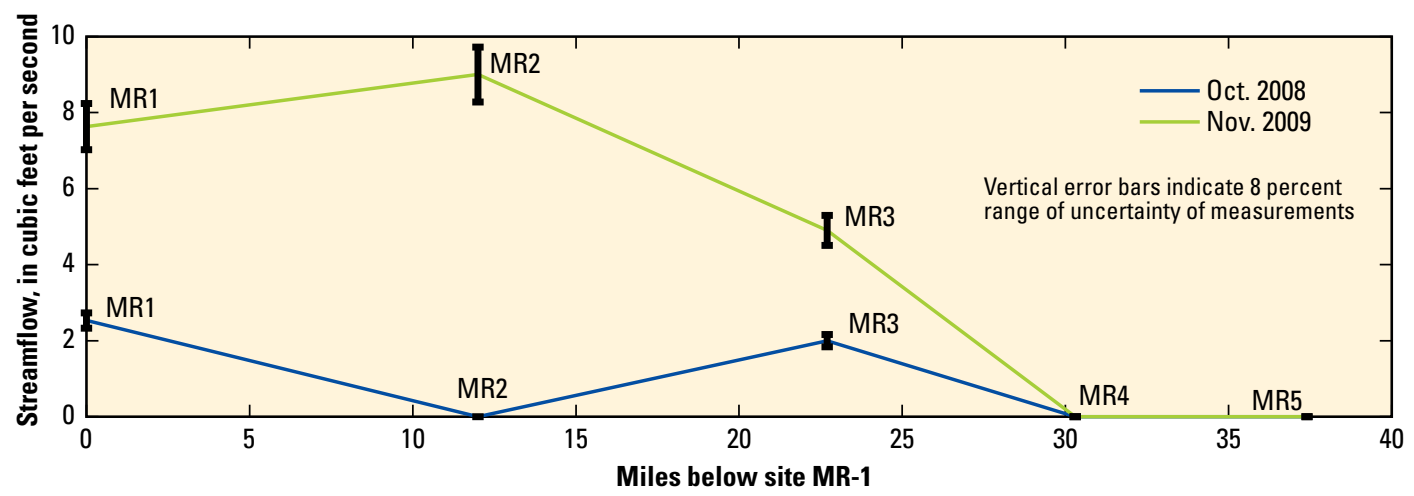

Figure 13. A, Locations of sites where streamflow was measured in the Marys River Area during the fall seepage runs of 2008 and 2009 and $B$, Streamflow measurements along Marys River between sites MR1 and MR5, upper Humboldt River basin, northeastern Nevada. 


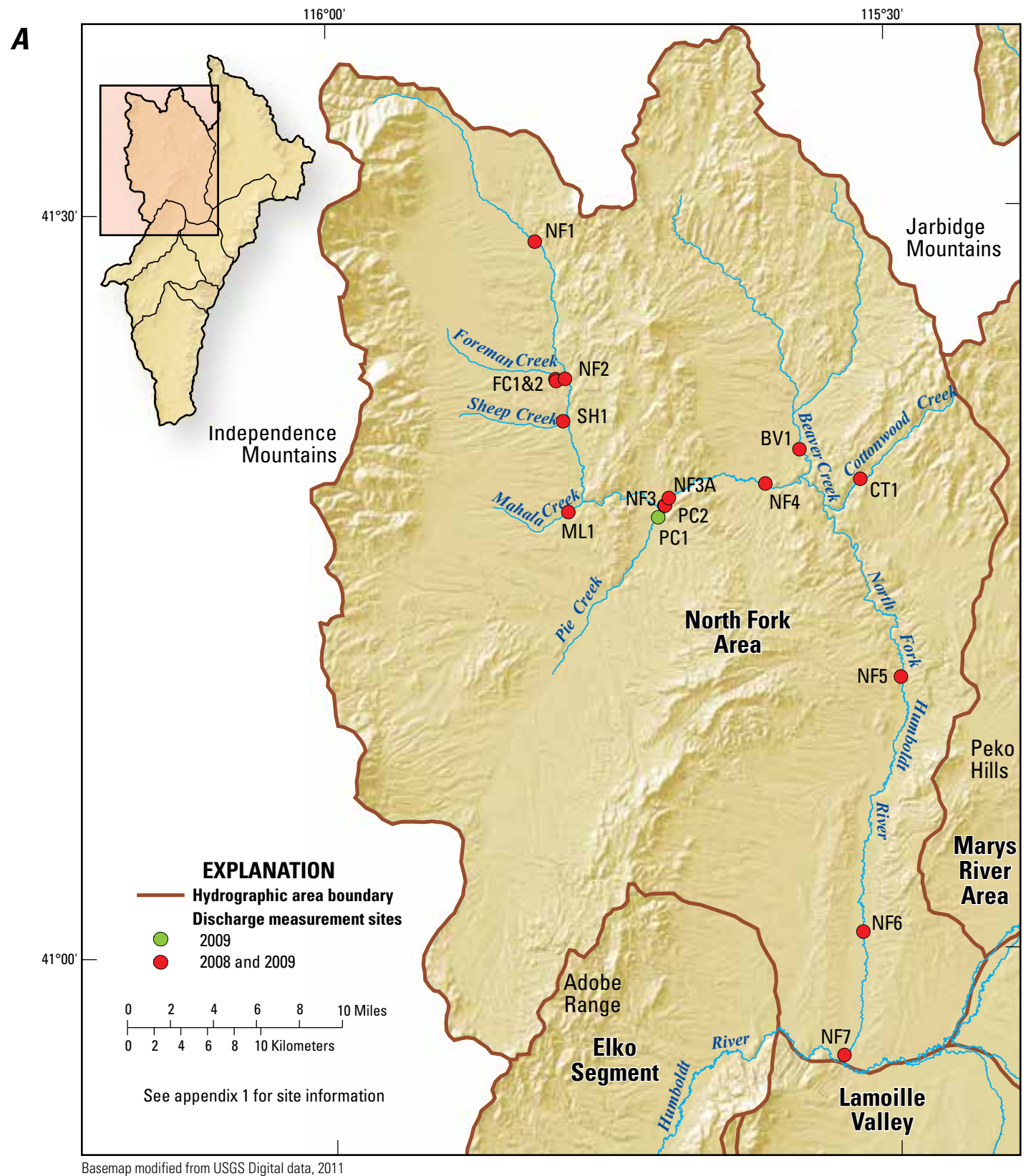

Basemap modified from USGS Digital data, 2011

Hillshade from 30-meter USGS National Elevation Dataset, 1999

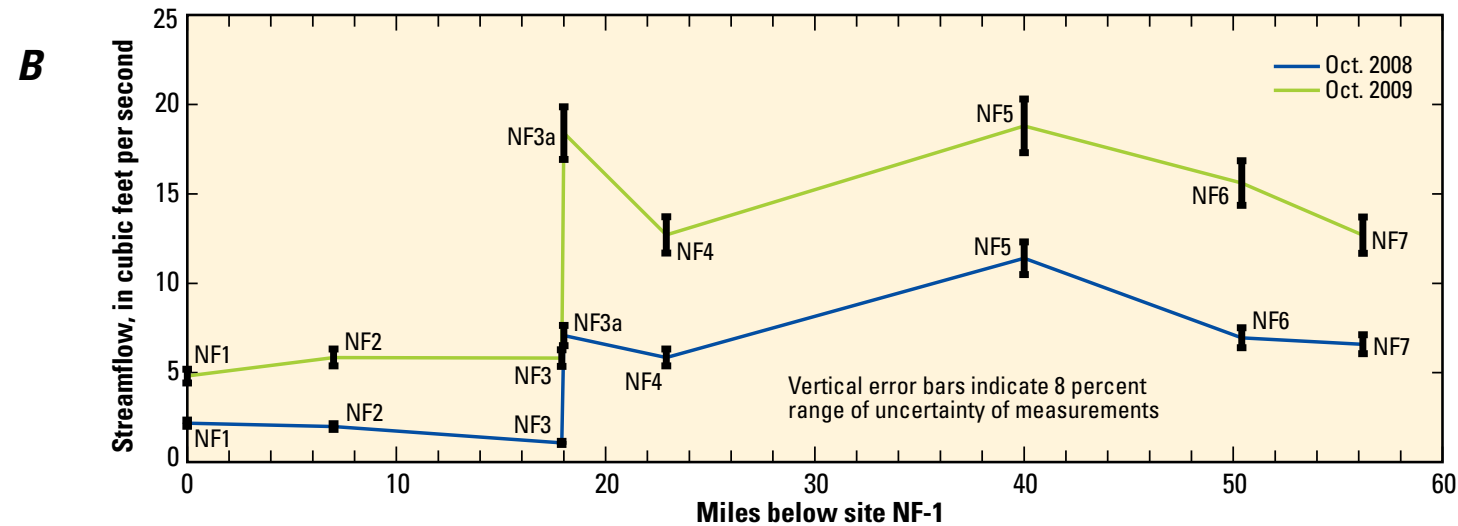

Figure 14. A, Locations of sites where streamflow was measured in the North Fork Area during the fall seepage runs, 2008 and 2009, and $B$, Streamflow measurements along the North Fork Humboldt River between sites NF1 and NF7, upper Humboldt River basin, northeastern Nevada. 


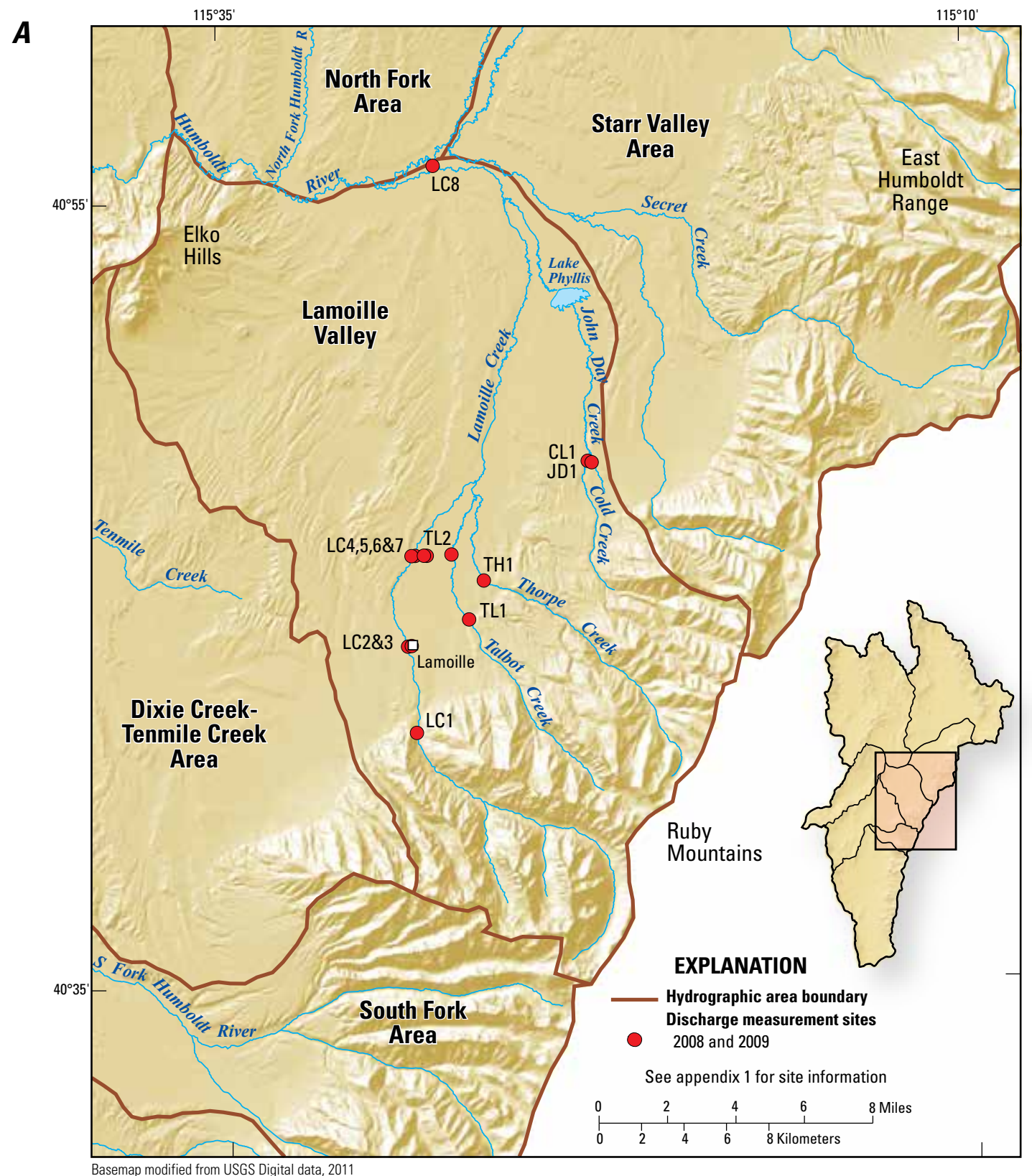

Basemap modified from USGS Digital data, 2011

Hillshade from 30-meter USGS National Elevation Dataset, 1999

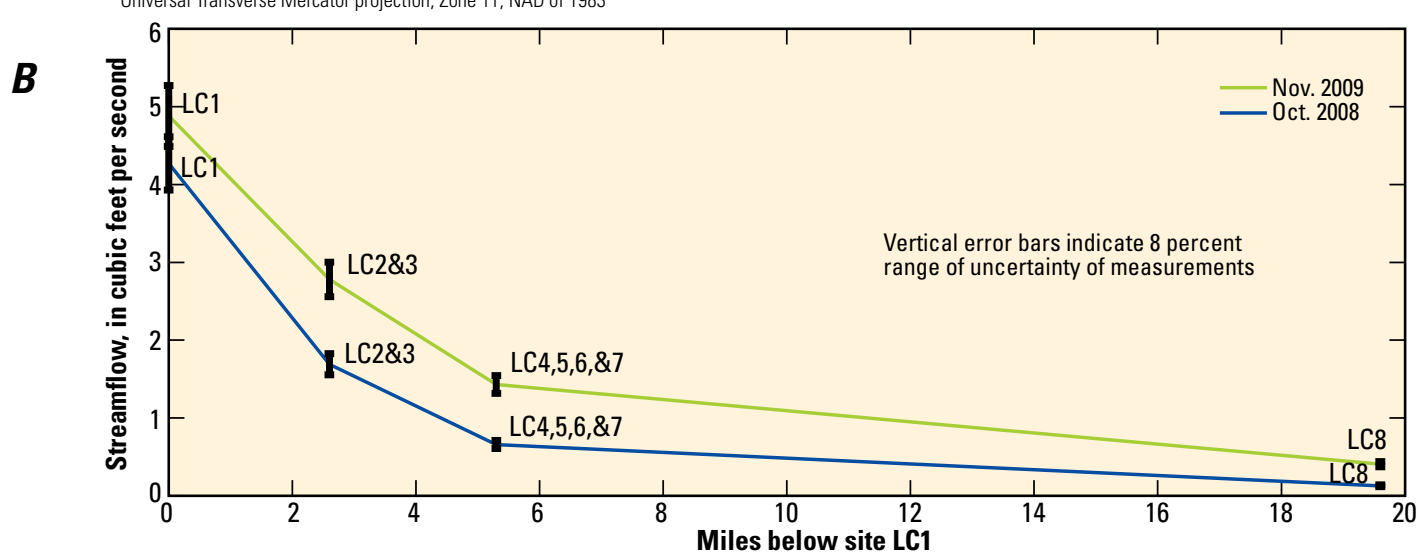

Figure 15. A, Locations of sites where streamflow was measured in Lamoille Valley during the fall seepage runs, 2008 and 2009 , and $B$, Streamflow measurements along Lamoille Creek and its diversions between sites LC1 and LC8, upper Humboldt River basin, northeastern Nevada. 
show that about 0.4 inch (in) of rain fell in early October 2008 (http://www.wrcc.dri.edu/cgi-bin/cliMAIN.pl?nv2573), and a similar amount fell during middle to late October 2009 (http://www.wrcc.dri.edu/cgi-bin/cliMAIN.pl?nv2573). These storms briefly affected the flow of Lamoille Creek in both years (fig. 11), but neither appears to have affected flow during the seepage runs.

\section{Huntington Creek}

Huntington Creek originates in southern Huntington Valley at Defue Spring (site HC1, fig. 16A). Between this site and HC4 at Jiggs, a channel distance of about $30 \mathrm{mi}$, Huntington Creek gradually lost about 3.6 and $4.3 \mathrm{ft}^{3} / \mathrm{s}$ in the 2008 and 2009 seepage runs, respectively (fig. 16B). These flow losses are believed to be due to infiltration to the underlying aquifer because no irrigation diversions were operating and no tributaries had any flow. South of Jiggs, Huntington Valley is bounded by permeable carbonate rocks and all mountain streams are ephemeral (Plume 2009, p. 7). As a result this 30-mi reach of Huntington Creek receives tributary inflow only during periods of flooding.

The increase in flow of Huntington Creek in 2008-09 between sites HC4 at Jiggs and HC8 at its confluence with the South Fork Humboldt River can be attributed to groundwater discharge to its channel and to a lesser extent tributary inflow (fig. 16A and $B$; appendixes 2 and 3). Between sites $\mathrm{HC} 4$ and HC5 the total gain in 2008 and 2009 was 0.82 and $1.7 \mathrm{ft}^{3} / \mathrm{s}$, respectively. In 2008 all of the gain was from groundwater; in $2009,0.34 \mathrm{ft}^{3} / \mathrm{s}$ was from Smith Creek and $1.4 \mathrm{ft}^{3} / \mathrm{s}$ was from groundwater. Between sites HC5 and HC6 total gains in 2008 and 2009 were 2.1 and $2.5 \mathrm{ft}^{3} / \mathrm{s}$, respectively, almost entirely from groundwater seepage. Between sites $\mathrm{HC} 6$ and $\mathrm{HC} 7$ total gains in 2008 and 2009 were 1.6 and $2.5 \mathrm{ft}^{3} / \mathrm{s}$, respectively. In 2008 the gain was $1 \mathrm{ft}^{3} / \mathrm{s}$ from Willow Creek and $0.56 \mathrm{ft}^{3} / \mathrm{s}$ from groundwater. In 2009 the gain was $1.2 \mathrm{ft}^{3} / \mathrm{s}$ from Willow Creek and $1.4 \mathrm{ft}^{3} / \mathrm{s}$ from groundwater. Thus, total groundwater discharge to the channel of Huntington Creek downstream from Jiggs during the 2008 and 2009 seepage runs was 3.5 $\mathrm{ft}^{3} / \mathrm{s}$ and $5.3 \mathrm{ft}^{3} / \mathrm{sec}$, respectively.

\section{South Fork Humboldt River}

The South Fork Humboldt River originates in the South Fork Area, passes through the Dixie Creek-Tenmile Creek Area, and joins the mainstem Humboldt River in the Elko Segment (fig. 17A). Flow is regulated by South Fork Reservoir in the Dixie Creek-Tenmile Creek Area and is reflected by the gap in the curves on figure $17 B$. Its main tributaries are Huntington Creek above South Fork Reservoir and Tenmile and Dixie Creeks below the reservoir. Sites SF1, SF2, SF3, and SF4 are in the reach of the South Fork Humboldt River above the reservoir. This reach of the river abruptly gains flow between sites SF3 and SF4. In 2008 the gain was $6.8 \mathrm{ft}^{3} / \mathrm{s}$ of which $3.9 \mathrm{ft}^{3} / \mathrm{s}$ was from Huntington Creek (site HC8) and
$2.9 \mathrm{ft}^{3} / \mathrm{s}$ was from groundwater discharge to the stream channel (appendix 2). In 2009 flow of the South Fork Humboldt River at its confluence with Huntington Creek was $11 \mathrm{ft}^{3} / \mathrm{s}$ (combined flow of sites SF3 and HC8), but instead of a downstream gain due to groundwater seepage there was an infiltration loss of $1.2 \mathrm{ft}^{3} / \mathrm{s}$ at site SF4 (appendix 3). However, this loss may not be significant because it barely exceeds the 8 percent uncertainty of the measurements.

The South Fork Humboldt River passes through a rugged canyon below South Fork Reservoir before entering the Elko Segment and joining the mainstem Humboldt River. The main hydrogeologic unit in this area is carbonate and clastic sedimentary rocks consisting of interbedded limestone, dolomite, siltstone, sandstone, and conglomerate (Smith and Ketner, 1972; Plume, 2009, pl.1). The flow in this reach of the river comes from releases from the reservoir, intermittent inflow from Tenmile and Dixie Creeks and discharge from numerous springs in the lower part of the canyon. Site SF5 is about $1.7 \mathrm{mi}$ below the reservoir and its flow in 2008 and 2009 (Tenmile Creek and reservoir releases) was 4.2 and $6.7 \mathrm{ft}^{3} / \mathrm{s}$, respectively (appendixes 2 and 3). During both seepage runs, releases from the South Fork Reservoir had minimal effects on flow of the river at site SF5 (http://water.nv.gov/data/ southfork/). The river gradually lost flow to channel infiltration between sites SF5 and SF8, a river channel distance of about $4.8 \mathrm{mi}$. However, the river abruptly gained flow from numerous springs discharging from carbonate and clastic sedimentary rocks between sites SF8 and SF11, a river channel distance of $4.6 \mathrm{mi}$. In October 1964 this reach of the river gained about $12 \mathrm{ft}^{3} / \mathrm{s}$ (Rush and Everett, 1966, p. 23). In 2008 and 2009 the gains were about $15 \mathrm{ft}^{3} / \mathrm{s}$ and $13 \mathrm{ft}^{3} / \mathrm{s}$, respectively. The largest part of the gain in $2009,8.6 \mathrm{ft}^{3} / \mathrm{s}$, occurred between sites SF9 and SF11, a river channel distance of less than $1 \mathrm{mi}$ (appendix 3). The South Fork Humboldt River lost nearly 2 and $4 \mathrm{ft}^{3} / \mathrm{s}$ in 2008 and 2009, respectively, between the mouth of the canyon at site SF11 and its confluence with the mainstem Humboldt River at site SF12 as a result of channel infiltration.

One of the main conclusions of the phase one report was that northward groundwater flow from Huntington Valley, across the Dixie Creek-Tenmile Creek Area, and through the hills between the Elko Hills and Pinyon Range to the Elko Segment was distributed along a 10-mi wide flow section (Plume, 2009, p. 13). However, the seepage run results indicate that this groundwater flow instead converges at the springs in the South Fork Humboldt River canyon.

\section{Mainstem Humboldt River}

The Humboldt River channel is the designated boundary between the Marys River and North Fork Areas on the north and the Starr Valley Area and Lamoille Valley on the south (fig. 18A). At the east end of the Elko Hills the river enters the Elko Segment and leaves the upper Humboldt River basin near Carlin. The main tributaries of the upper Humboldt River are Marys River, Lamoille Creek, North Fork Humboldt River, 


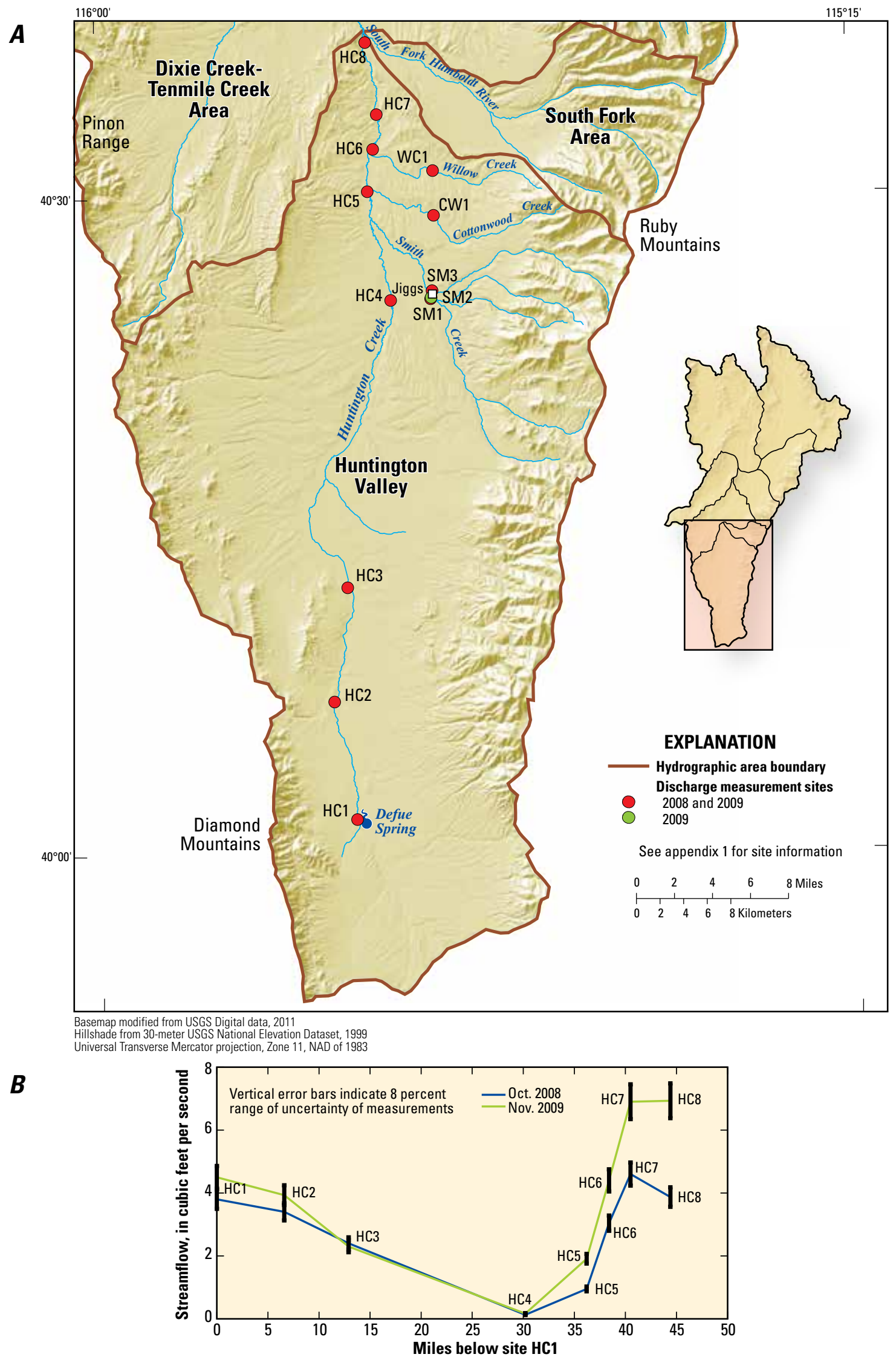

Figure 16. A, Locations of sites where streamflow was measured in Huntington Valley during the fall seepage runs, 2008 and 2009, and $B$, Streamflow measurements along Huntington Creek between sites $\mathrm{HC} 1$ and $\mathrm{HC}$, upper Humboldt River basin, northeastern Nevada. 


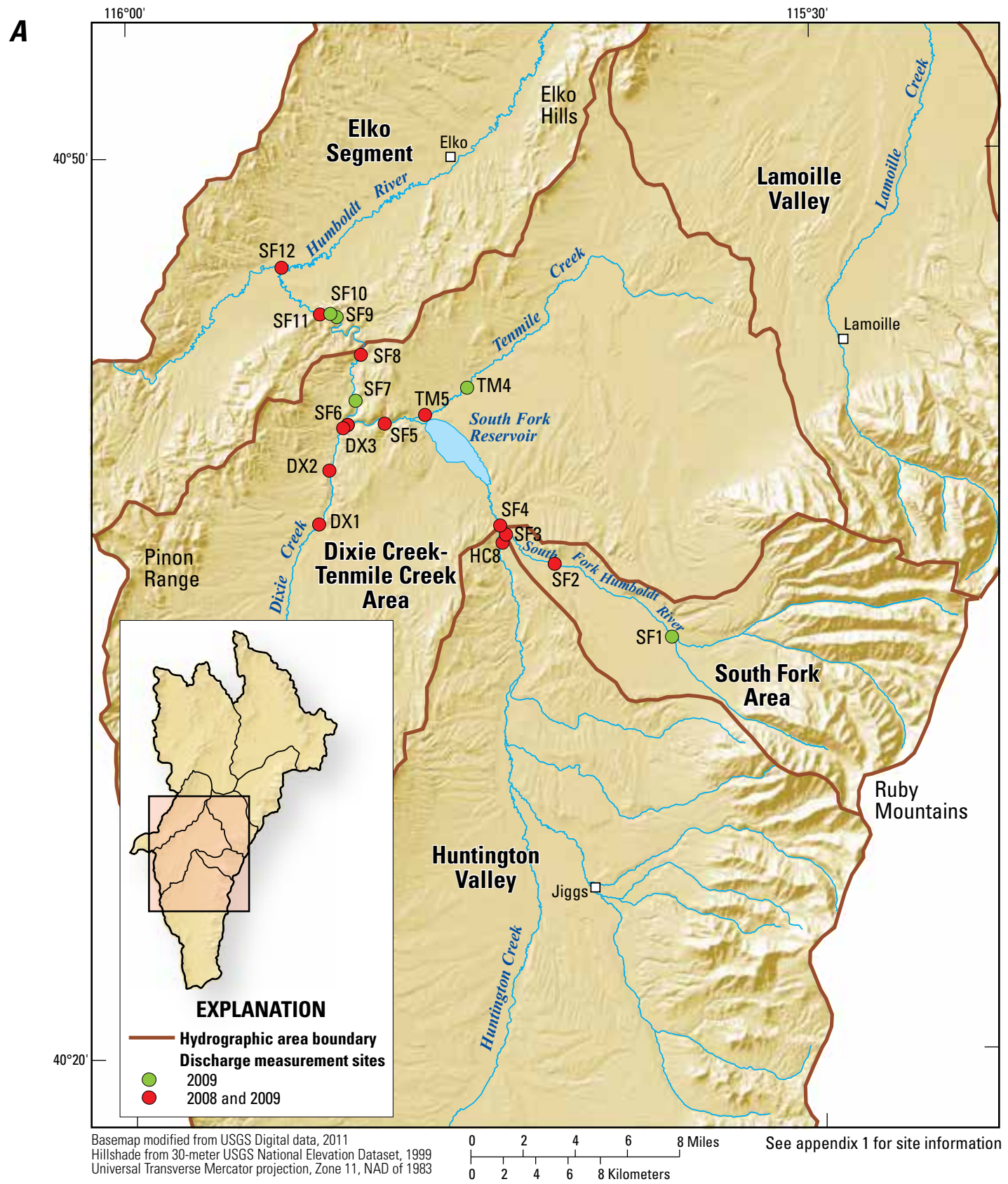

$\boldsymbol{B}$

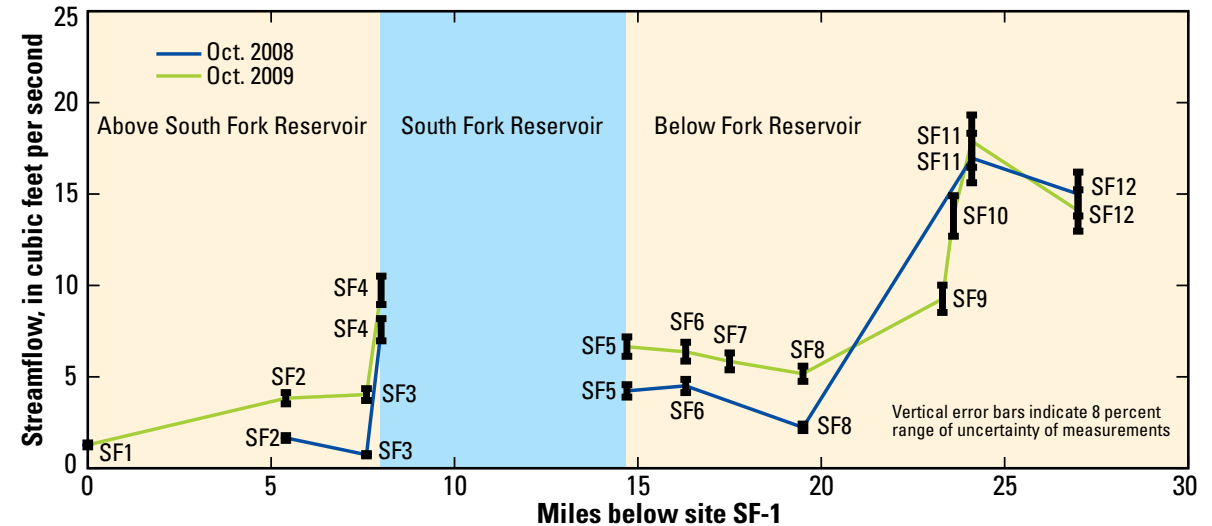

Figure 17. A, Locations of sites where streamflow was measured on the South Fork Humboldt River during the fall seepage runs, 2008-09, and B, Streamflow measurements along the South Fork Humboldt River between sites SF1 and SF12, upper Humboldt River basin, northeastern Nevada. 


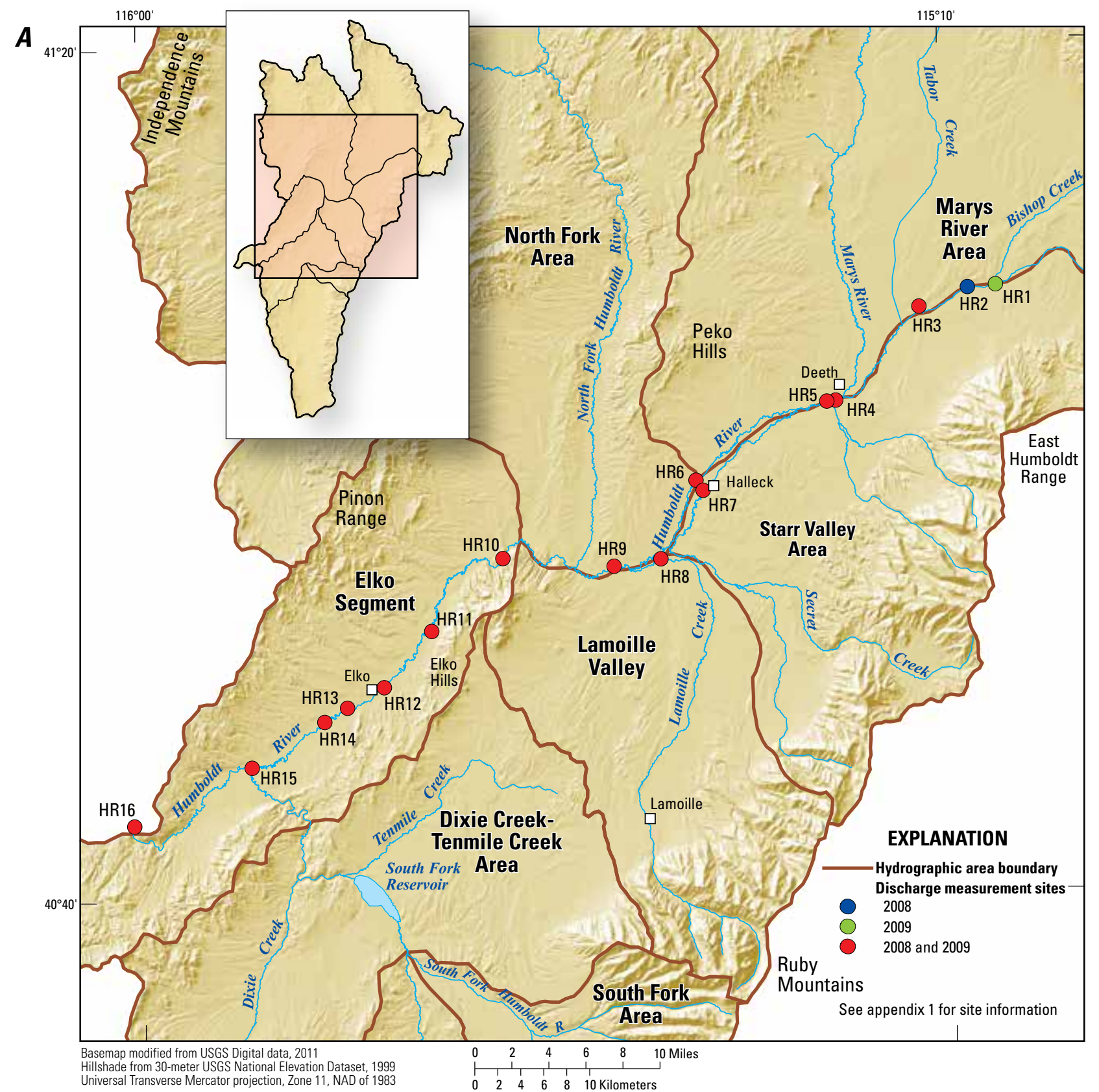

B

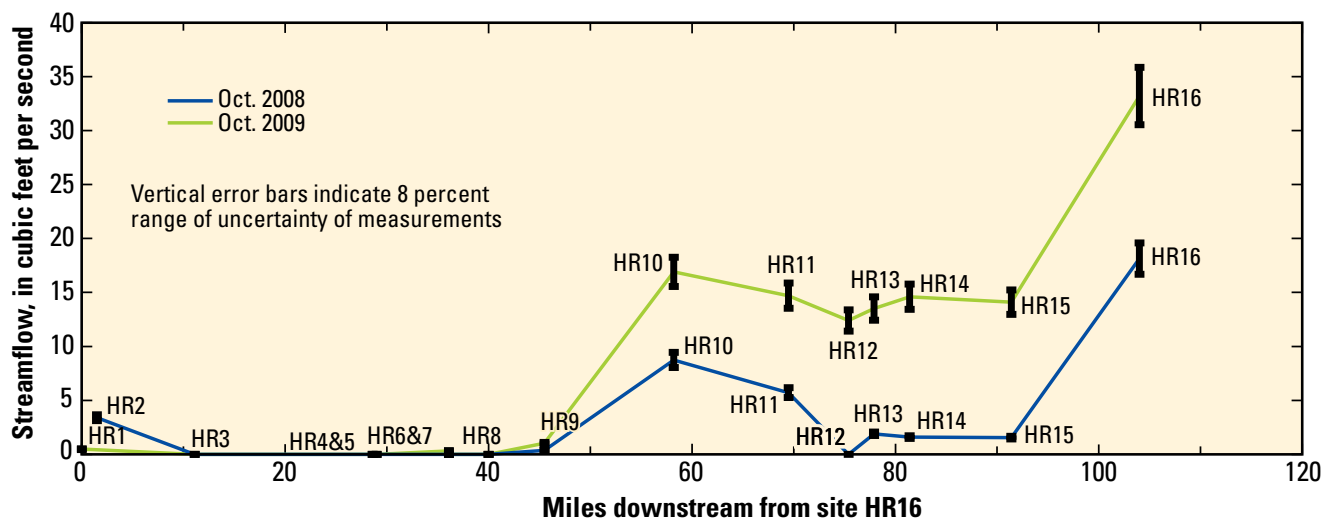

Figure 18. A, Locations of sites where streamflow was measured on the mainstem Humboldt River during the fall seepage runs, 2008 and 2009, and $B$, Streamflow measurements along the mainstem Humboldt River between sites HR1 and HR16, upper Humboldt River basin, northeastern Nevada. 
and South Fork Humboldt River. Several small streams in the Starr Valley and Marys River Areas contribute flow to the river during the snowmelt runoff, but contribute little flow during the baseflow period of late summer and fall. Flow of the upper Humboldt River was measured at 15 sites in 2008 and 2009. Four of these are site pairs where the river has two channels (sites HR4 and HR5 at Deeth and HR6 and HR7 near Halleck). The uppermost site is just above the confluence with Bishop Creek (HR1) and the lowermost is near Carlin (HR16, USGS site number 10321000), a river channel distance of about $104 \mathrm{mi}$ (fig. 18A and B). In 2008-09 the Humboldt River had no flow in its reaches above the North Fork Humboldt River (appendixes 2 and 3) with four exceptions: (1) flow was $0.48 \mathrm{ft}^{3} / \mathrm{s}$ in 2009 at site HR1 just above the confluence with Bishop Creek, (2) flow was $3.4 \mathrm{ft}^{3} / \mathrm{s}$ in 2008 at site HR2 probably from tributary inflow from Bishop Creek, (3) flow was $0.31 \mathrm{ft}^{3} / \mathrm{s}$ in its right channel near Halleck at site HR6 in 2009, and (4) flow was 0.36 and $1.0 \mathrm{ft}^{3} / \mathrm{s}$ in 2008 and 2009, respectively, above the confluence with the North Fork Humboldt River at site HR9. Flow of the upper Humboldt River was well below average in 2008-09 which accounts partly for the minimal baseflow. In years of normal precipitation and high-altitude snowpack, baseflow might be present in most of this reach of the river.

The upper Humboldt River abruptly gained about $8.4 \mathrm{ft}^{3} / \mathrm{s}$ in 2008 and $16 \mathrm{ft}^{3} / \mathrm{s}$ in 2009 between sites HR9 and HR10. Most of these gains were due to tributary inflow from the North Fork Humboldt River (site NF7 appendixes 2 and 3). However the upper Humboldt River also gained flow, $1.8 \mathrm{ft}^{3} / \mathrm{s}$ in 2008 and $3.2 \mathrm{ft}^{3} / \mathrm{s}$ in 2009 , as groundwater discharge to its channel in the reach from below its confluence with the North Fork Humboldt River to site HR10. Flow of the Humboldt River at the Elko gaging station (site HR10) increased by about 0.7 and $1 \mathrm{ft}^{3} / \mathrm{s}$ during the 2008 and 2009 seepage runs, respectively (fig. 11). Both of these increases in flow during the seepage runs makes the magnitude of the gains attributed to groundwater uncertain.

Between sites HR10, HR11, and HR12 the river lost flow, $8.7 \mathrm{ft}^{3} / \mathrm{s}$ in 2008 and $4.5 \mathrm{ft}^{3} / \mathrm{s}$ in 2009 , as infiltration to the underlying aquifer. Between sites HR12 and HR15 the river gained about $1.5 \mathrm{ft}^{3} / \mathrm{s}$ in 2008 and $1.7 \mathrm{ft}^{3} / \mathrm{s}$ in 2009 . However, the changes in flow over the reaches of river channel between each of these five pairs of sites are very uncertain because all are well within the uncertainty of the measurements (fig. 18B).

The upper Humboldt River again abruptly gained flow between sites HR15 and HR16- $17 \mathrm{ft}^{3} / \mathrm{s}$ in 2008 and $19 \mathrm{ft}^{3} / \mathrm{s}$ in 2009. Most of these gains were due to tributary inflow from the South Fork Humboldt River, which originates as spring discharge over a short reach of river channel. The Humboldt River channel also appears to have gained $1.6 \mathrm{ft}^{3} / \mathrm{s}$ in 2008 and $5.0 \mathrm{ft}^{3} / \mathrm{s}$ in 2009 (appendixes 2 and 3) downstream from the confluence with the South Fork Humboldt River. However, the 2008 gain is well within the uncertainties of the measurements used to compute it. Finally, flow of the Humboldt River at the Carlin gaging station (site HR16) increased from 15 to $18 \mathrm{ft}^{3} / \mathrm{s}$ during the 2008 seepage run and fluctuated between 32 and $35 \mathrm{ft}^{3} / \mathrm{s}$ during the 2009 seepage run (fig. 11). As a result, apparent flow gains of the Humboldt River downstream from the South Fork Humboldt River are considered to be very uncertain.

Results of the October 2008 and November 2009 seepage runs on the upper Humboldt River and its tributaries indicate that in years of below-average runoff, the reach of the river east of the Elko Hills has minimal baseflow, and in the reaches to the west, most baseflow comes from tributary inflow of the North Fork and South Fork Humboldt Rivers. However, the flow of these two tributaries comes from groundwater discharge to their respective channels where they have incised canyons in bedrock. The canyon incised by the North Fork Humboldt River is in volcanic rocks 16 to 26 mi upstream from its mouth. The canyon incised by the South Fork Humboldt River is in carbonate rocks 3 to 7 mi upstream from its mouth.

\section{Shallow Flood Plain Groundwater Levels}

To understand the interactions between flow of the Humboldt River and groundwater, four shallow wells were drilled across the river flood plain near Elko in November 2008 (fig. 19). Well MR-1 was drilled on the left (south) bank of the river, MR-2 was drilled about $110 \mathrm{ft}$ from the left bank, MR-3 was drilled at $530 \mathrm{ft}$, and MR-4 was drilled at 1,900 ft from the left bank. The wells range from 14.5 to $26 \mathrm{ft}$ in depth and all four penetrated 4 to $12 \mathrm{ft}$ of soil, silt, and clay and 3 to $13 \mathrm{ft}$ of clean sand and gravel (table 9). Wells MR-1 and MR-4 bottomed in hard green clay. This clay is at an altitude of about $5,022 \mathrm{ft}$ at both wells and may underlie the Humboldt River flood plain and adjacent areas in the Elko Segment.

Pressure transducers with recorders were installed in each of the wells and in the river in early March 2010 to record hourly depths to groundwater and river stage. Figure 20 shows five hydrographs, one for river-stage altitude and four for water-level altitude in the wells for the period early March 2010 through September 2011. The curves on the graph show that shallow groundwater beneath the Humboldt River flood plain at wells MR-1, MR-2, and MR-3 and flow in the river are well connected at distances at least as far as well MR-3, $530 \mathrm{ft}$ from the left bank of the river. Water levels in the three wells closely track changes in the stage of the river. In contrast, flow in the river and water levels at well MR-4, 1,900 $\mathrm{ft}$ from the left bank, are not as well connected. Water-level responses in this well to abrupt changes in river stage were much more gradual and subdued than water levels in wells MR-1, MR-2 and MR-3. Even though data for well MR-4 are missing during the streamflow peak of 2010, its hydrograph is consistently subdued compared with hydrographs for the other three wells. Water-level changes in MR-4 in 2011 were also subdued but more closely tracked river stage because the 2011 spring and early summer runoff was more prolonged than in 2010. The MR-4 hydrographs both indicate that the connection between the river and shallow flood plain aquifer becomes tenuous between 530 and 1,900 ft from the left bank of the river. 


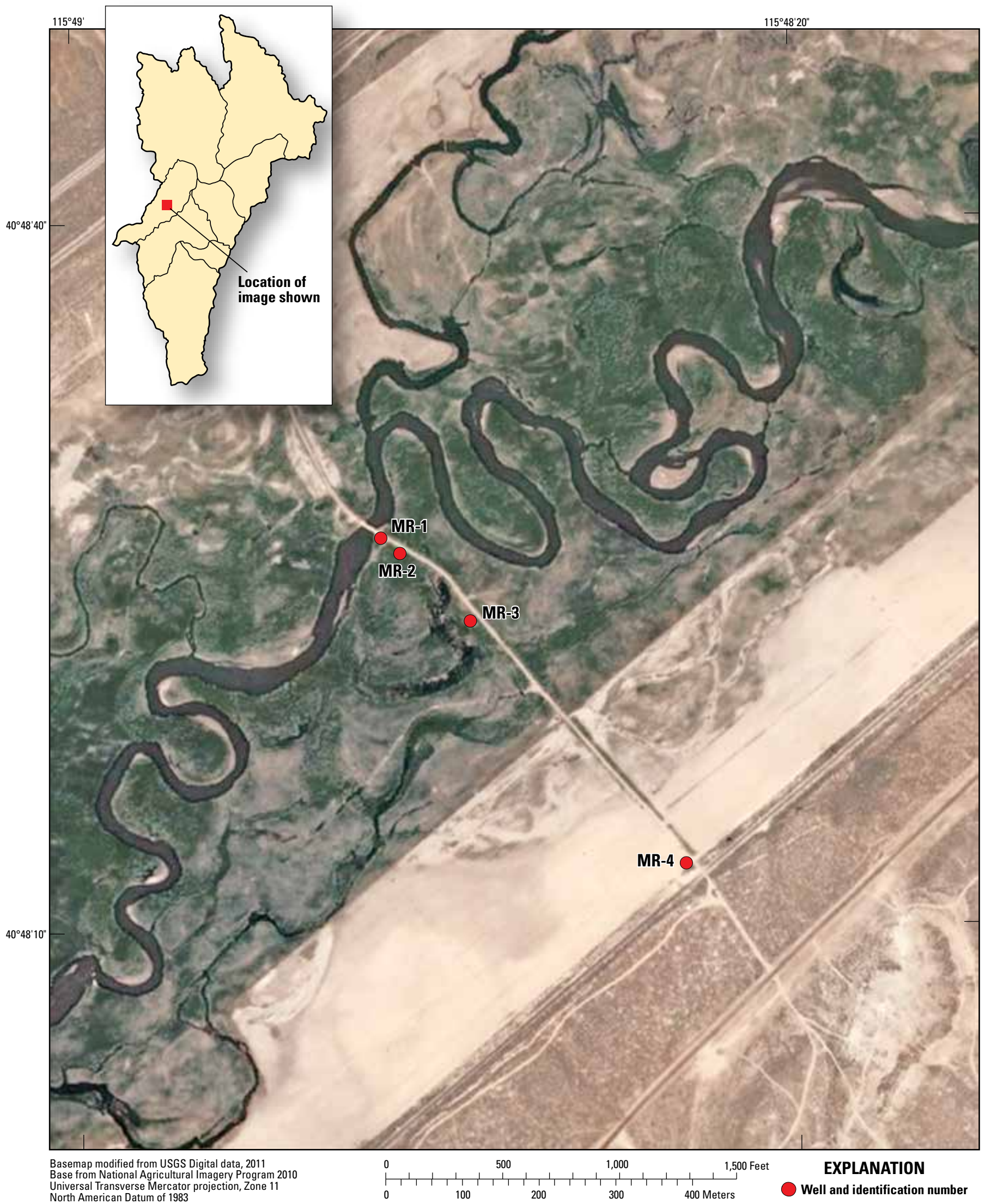

Figure 19. Location of shallow wells MR-1, MR-2, MR-3 and MR-4 drilled in the Humboldt River flood plain below Elko, upper Humboldt River basin, northeastern Nevada. 
Table 9. Lithology of Humboldt River flood plain deposits penetrated by wells MR-1, MR-2, MR-3, and MR-4 near Elko, upper Humboldt River basin, northeastern Nevada.

[See figure 19 for well locations]

\begin{tabular}{|c|c|c|c|c|c|}
\hline \multirow{2}{*}{ Well name } & \multirow{2}{*}{ Nevada log number ${ }^{1}$} & \multicolumn{2}{|c|}{ Depth (feet) } & \multirow{2}{*}{$\begin{array}{l}\text { Thickness } \\
\text { (feet) }\end{array}$} & \multirow{2}{*}{ Lithology } \\
\hline & & From & To & & \\
\hline \multirow[t]{8}{*}{ MR-1 } & 107797 & 0 & 7 & 7 & Road fill \\
\hline & & 7 & 9 & 2 & Brown silty clay \\
\hline & & 9 & 9.5 & 0.5 & Fine brown sand \\
\hline & & 9.5 & 15 & 5.5 & Sandy gravel, rounded pebbles up to 1 inch \\
\hline & & 15 & 17 & 2 & Gravel, rounded pebbles to 1 inch \\
\hline & & 17 & 18 & 1 & Sand \\
\hline & & 18 & 22 & 4 & Gravel \\
\hline & & 22 & 22.5 & 0.5 & Greenish-brown clay, hard drilling \\
\hline \multirow[t]{5}{*}{ MR-2 } & 107796 & 0 & 2 & 2 & Cobbly road fill \\
\hline & & 2 & 4 & 2 & Gravelly sand \\
\hline & & 4 & 6 & 2 & Sandy clay \\
\hline & & 6 & 13 & 7 & Clayey sand \\
\hline & & 13 & 14.5 & 1.5 & Gravel and sand \\
\hline \multirow[t]{6}{*}{ MR-3 } & 107795 & 0 & 0.5 & 0.5 & Black clay soil \\
\hline & & 0.5 & 1 & 0.5 & Gravel \\
\hline & & 1 & 5 & 4 & Black silty clay \\
\hline & & 5 & 9 & 4 & Sand and gravel \\
\hline & & 9 & 11.5 & 2.5 & Sandy gravel, rounded pebbles to $1 \mathrm{inch}$ \\
\hline & & 11.5 & 14.5 & 3 & Sand and gravel with clay stringers \\
\hline \multirow[t]{4}{*}{ MR-4 } & 107794 & 0 & 8 & 8 & Brown silty sand, little clay \\
\hline & & 8 & 12 & 4 & Brown silty clay \\
\hline & & 12 & 25.5 & 13.5 & $\begin{array}{l}\text { Rounded gravel to } 1.5 \text { inches and cobbles to } \\
4 \text { inches }\end{array}$ \\
\hline & & 25.5 & 26 & 0.5 & Green hard clay \\
\hline
\end{tabular}

${ }^{1}$ Nevada drillers' logs can be accessed at http://water.nv.gov/data/welllog/

Together the five hydrographs show substantial differences in response to the snowmelt runoff in 2010 and 2011. The spring 2010 runoff began in mid-April and was over before mid-June. In contrast, the spring 2011 runoff began in midFebruary and did not begin to decline until early July. The duration of the 2011 runoff was more than twice that in 2010 because of the substantially greater snowpack especially at low altitudes. In addition, cool temperatures in April and May ensured that the snowpack melted gradually.

The spring 2010 runoff was short because of a belowaverage late spring snowpack and warm temperatures. As a result the limited snowpack melted so rapidly that peak stages exceeded those of the substantially longer and larger 2011 runoff. From late April through early July, river stage was a few tenths of a foot higher than groundwater levels in the adjacent flood plain at wells MR-1, MR-2, and MR-3, and streamflow moved into bank storage in the shallow aquifer. The spring snowmelt runoff began to decline by about June 9 , and the decline in stage continued through the summer to around August 6. By early July, river stage was lower than groundwater levels in the flood plain and groundwater in bank storage began to be released back into the river channel.

River stage again began to rise around August 6 and continued through early October. The period during which flow of the upper Humboldt River can be diverted for irrigation use each year is April 15 to August 15 (Malone, 1932, p. 13) and this helps explain the rising stage of the river after August 15. However, the reason for the rise in stage between August 6 and 15 is not clear unless irrigators were already ending diversions of streamflow. By about mid-October, river stage and water levels in well MR-1, MR-2, and MR-3 were similar, differing by only a few tenths of a foot; this continued through the winter of 2010-11.

The peaks of the stage hydrograph and hydrographs for the three wells nearest the river (wells MR-1, MR-2, and MR-3) closely coincide from October 2010 through February 2011. From late February through mid-June 2011, river stage rose during several warm periods separated by intervening cool periods and lower stages. From early March through late July 2011, river stage was higher than groundwater levels in 


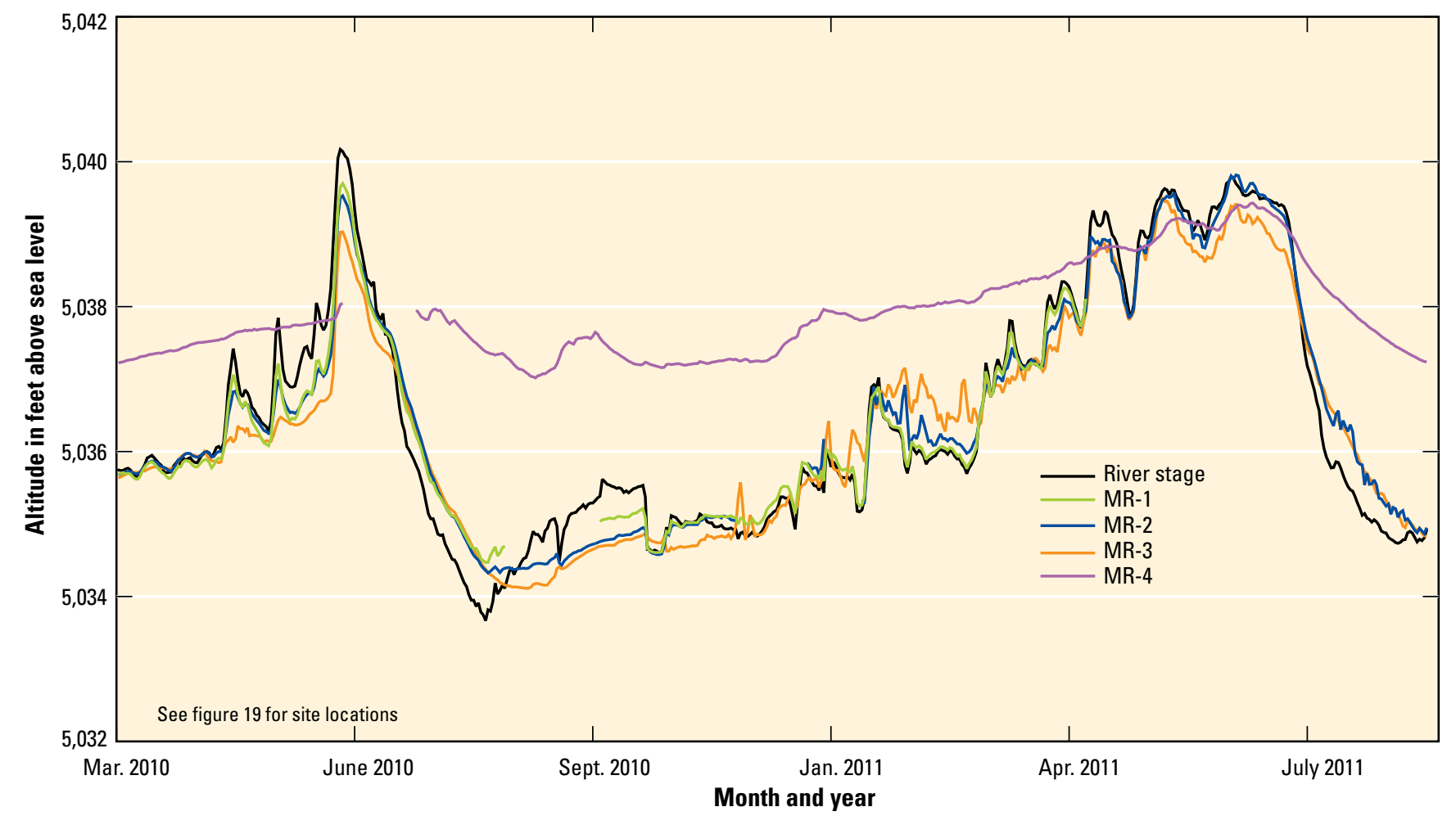

Figure 20. Stage of the Humboldt River and groundwater levels in the adjacent flood plain near Elko, upper Humboldt River basin, northeastern Nevada.

the adjacent flood plain. However, the volume of streamflow available for bank storage exceeded the capacity of the shallow aquifer to store the water as indicated by water levels that rose to land surface at wells MR-2 and MR-3. The spring snowmelt runoff began to decline by about mid-June, and by late July, stream stage had declined below water levels in the shallow aquifer along the river flood plain releasing water in bank storage back to the river channel.

\section{Conclusions}

The present channel of the Humboldt River occupies a flood plain that ranges in width from about 1,000 feet (ft) in the canyon through the Elko Hills to 1 to 3 miles in upstream and downstream reaches. This wide flood plain was created by the ancient Humboldt River during the Lamoille and Angel Lake glacial substages when flows were much higher than at present. The ancient Humboldt River incised a channel in deposits of a Pliocene lake, and as flows gradually decreased after the last glacial substage the present Humboldt River came to occupy a narrow part of the flood plain. Flood plain deposits probably are less than $50 \mathrm{ft}$ thick and consist of sand and gravel interbedded with silt and clay that function as a shallow water-table aquifer. During the spring snowmelt each year, this aquifer is recharged by streamflow that enters the aquifer as bank storage. Later in the summer, as stream stage declines, the same water leaves bank storage and helps sustain flow in the river. The timing and duration of the snowmelt runoff each year depend on the volume of high-altitude snowpack and on daily temperatures during spring and early summer. Along a reach of the river near Elko, flood plain deposits are more permeable than adjacent and underlying fine-grained sediments of the Pliocene lake and, as a result, the two are not well connected hydraulically. This is true for most reaches of the river because it has very little baseflow that can be attributed to groundwater discharge to its channel. Water levels in flood plain deposits change in response to changes in stage of the Humboldt River. Water-level changes in sediments of the Pliocene lake have little or no influence on water levels in flood plain deposits because of the poor hydraulic connection between the two.

\section{Summary}

Elko County, Nevada, and state water-resource managers need information that will enable them to make informed decisions regarding future use and development of the groundwater resources of the upper Humboldt River basin. To address these needs and concerns, the U.S. Geological Survey, in cooperation with Elko County, conducted a study to develop an improved understanding of the water resources of the upper Humboldt River basin in northeastern Nevada. This report 
summarizes the findings of phase two of the study, which was conducted in federal fiscal years 2009-11, and describes the lithologic and hydrologic properties of basin-fill aquifers, presents a water budget for the period 1971-2000, and explains interactions between groundwater and surface water.

The upper Humboldt River basin covers an area of about 4,360 square miles in northeastern Nevada and consists of eight hydrographic areas-Marys River Area, Starr Valley Area, North Fork Area, Lamoille Valley, South Fork Area, Huntington Valley, Dixie Creek-Tenmile Creek Area, and the Elko Segment. These eight areas are the headwaters of the Humboldt River, and nearly all of the annual flow of the river in years of average flow originates from this area. The main tributaries of the upper Humboldt River are South Fork Humboldt River, North Fork Humboldt River, Lamoille Creek, and Marys River.

Basin-fill deposits function as the principal aquifers in the upper Humboldt River basin. Over much of the basin lowlands, the upper $200 \mathrm{ft}$ of these deposits consist of a mixture of fine- and coarse-grained sediments that were deposited in a lake of middle to late Pliocene age. The deposits consist of relatively thick sequences of clay and silt deposited during high stands of the lake and interbeds of sand and gravel deposited by streams during low stands. Fine-grained lacustrine sediments compose from 30 to more than 70 percent of the deposits and mean values of transmissivity are less than 1,000 feet squared per day.

Total inflow to the upper Humboldt River basin, 3,330,000 acre-feet per year (acre-ft/yr), comes entirely from annual precipitation. Total outflow is assumed to equal inflow and occurs as evapotranspiration of precipitation $(2,530,000$ acre-ft/yr), net evapotranspiration from discharge areas (467,000 acre-ft/yr), flow of the Humboldt River (316,000 acre-ft/yr), subsurface flow (4,100 acre-ft/yr), and municipal and domestic pumpage (13,000 acre-ft/yr). The uncertainty of this water budget is estimated to be about 25 percent.

The results of October 2008 and November 2009 seepage runs on the upper Humboldt River and its tributaries indicate that in years of below-average runoff, the reach of the river east of the Elko Hills has minimal baseflow, and in reaches to the west, most baseflow comes from tributary inflow of the North Fork and South Fork Humboldt Rivers. However, the flow of these two tributaries comes from groundwater discharge to their respective channels where they have incised canyons in bedrock. The canyon incised by the North Fork Humboldt River is in volcanic rocks 16 to 26 miles upstream from its mouth. The canyon incised by the South Fork Humboldt River is in carbonate rocks 3 to 7 miles upstream from its mouth.

Stage of the Humboldt River and water levels in the adjacent water-table aquifer were monitored at a site near Elko between March 2010 and September 2011. In 2010 streamflow was going into bank storage in late April and continued through the end of June at which time water from bank storage began discharging back into the river channel. In 2011 streamflow was going into bank storage in late February and this continued through late July at which time groundwater began discharging back into the river channel.

The results of the 2008-09 seepage runs and stage and water-level altitudes measured adjacent to the river near Elko suggest that the aquifers recharged by flow of the Humboldt River are mainly those in its flood plain. These aquifers are shallow and may not be well connected with the basin-fill aquifers of the upper Humboldt River basin away from the river flood plain.

\section{Acknowledgments}

This study was done in cooperation with Elko County, Nevada, and is the result of discussions with, and input from, the Elko County Board of Commissioners and Elko County Water Planning Commission over several years. The authors thank property owners in the study area for providing USGS field personnel access to stream channels during the fall seepage runs of 2008 and 2009. The authors also thank Alan Wallace with USGS in Reno for helpful discussions regarding Cenozoic basins in northeastern Nevada. Finally, the authors express their thanks to Bruce and Sydney Miller for granting the USGS permission to install the four shallow wells on their ranch along the Humboldt River flood plain near Elko.

\section{References Cited}

Allander, K.K., Gortsema, G.C., Hutchinson, D.D., and Schwartzenberger, James, 2001, Water resources data, Nevada-Water year 2000: U.S. Geological Survey WaterData Report NV-00-1, 570 p.

Berger, D.L., 2006, Hydrogeology and water resources of Ruby Valley, northeastern Nevada: U.S. Geological Survey Scientific Investigations Report 2005-5247, 39 p.

Cardinalli, J.L., Roach, L.M., Rush, F.E., and Vasey, B.J., 1968, State of Nevada hydrographic areas: Nevada Division of Water Resources map, scale 1:500,000.

Coats, R.R., 1987, Geology of Elko County, Nevada: Nevada Bureau of Mines and Geology Bulletin 101, 112 p.

Daly, Christopher, Neilson, R.P., and Phillips, D.L., 1994, A statistical-topographic model for mapping climatological precipitation over mountainous terrain: Journal of Applied Meteorology, v. 33, no. 2, p. 140-158.

Dudley, W.W., Jr., 1967, Hydrogeology and ground-water flow system of the central Ruby Mountains, Nevada: Urbana, Ill., University of Illinois, unpublished doctoral thesis, $107 \mathrm{p}$.

Eakin, T.E., and Lamke, R.D., 1966, Hydrologic reconnaissance of the Humboldt River Basin, Nevada: Nevada Department of Conservation and Natural Resources Water Resources Bulletin 32, 107 p. 
Henry, C.D., 2008, Ash-flow tuffs and paleovalleys in northeastern Nevada-Implications for Eocene paleogeography and extension in the Sevier hinterland, northern Great Basin: Geosphere v. 4, no. 1, p. 1-35.

Howard, K.A., 2000, Geologic map of the Lamoille quadrangle, Elko County, Nevada: Nevada Bureau of Mines and Geology Map 125.

Huete, A.R., Didan, Kamel, Miura, Tomoaki, Rodriguez, E.P., Gao, Xiang, and Ferreira, L.G., 2002, Overview of the radiometric and biophysical performance of the MODIS Vegetation Indices: Remote Sensing of Environment, v. 83 p. 195-213.

Jeton, A.E., Watkins, S.A., and Huntington, Justin, 2006, Evaluation of precipitation estimates from PRISM for the 1961-90 and 1971-2000 data sets, Nevada: U.S. Geological Survey Scientific Investigations Report 2005-5291, 54 p.

Lohman, S.W., and others, 1972, Definitions of selected ground-water terms-Revisions and conceptual refinements: U.S. Geological Survey Water-Supply Paper 1988, $21 \mathrm{p}$.

Malone, G.W., 1932, Humboldt River distribution and different features affecting these deliveries for the years 1927 to 1931, inclusive: Carson City, Nev., State Printing Office, $111 \mathrm{p}$.

Maurer, D.K., Plume, R.W., Thomas, J.M., and Johnson, A.K., 1996, Water resources and effects of changes in groundwater use along the Carlin Trend, north-central Nevada: U.S. Geological Survey Water-Resources Investigations Report 96-4134, 146 p.

Maurer, D.K., Lopes, T.J., Medina, R.L.; Smith, J.L., 2004, Hydrogeology and hydrologic landscape regions of Nevada: Scientific Investigations Report 2004-5131, 41 p.

Moreo, M.T., Laczniak, R.J., and Stannard, D.I., 2007, Evapotranspiration rate measurements of vegetation typical of ground-water discharge areas in the Basin and Range carbonate-rock aquifer system, Nevada and Utah, September 2005-August 2006: U.S. Geological Survey Scientific Investigations Report 2007-5078, 36 p., accessed March 6, 2009, at http://pubs.usgs.gov/sir/2007/5078/

Nichols, W.D., 2000, Regional ground-water evapotranspiration and ground-water budgets, Great Basin, Nevada: U.S. Geological Survey Professional Paper 1628, 82 p.

Plume, R.W., 2009, Hydrogeologic framework and occurrence and movement of groundwater in the upper Humboldt River Basin, northeastern Nevada: U.S. Geological Survey Scientific Investigations Report 2009-5014, 22 p.

Prudic, D.E., Niswonger, R.G., and Plume, R.W., 2006, Trends in streamflow on the Humboldt River between Elko and Imlay, Nevada, 1950-99: U.S. Geological Survey Scientific Investigations Report 2005-5199, 58 p.
Qi, Jiaguo, Chehbouni, Abdelghani, Huete, A.R., Kerr, Y.H., and Sorooshian, Soroosh, 1994, A modified soil adjusted vegetation index: Remote Sensing of Environment, v. 48, p. 119-126.

Rouse, J.W., Haas, R.H., Schell, J.A., and Deering, D.W., 1973, Monitoring vegetation systems in the great plains with ERTS: Third ERTS Symposium, NASA SP-351, v. 1, p. 309-317.

Rush, F.E., 1968, Index of hydrographic areas in Nevada: Nevada Division of Water Resources Information Report 6, $38 \mathrm{p}$.

Rush, F.E., and Everett, D.E., 1966, Water-resources appraisal of the Huntington Valley area, Elko and White Pine Counties, Nevada: Nevada Department of Conservation and Natural Resources Water Resources-Reconnaissance Series Report 35, 40 p.

Sharp, R.P., 1938, Pleistocene glaciation in the Ruby-East Humboldt Range, northeastern Nevada: Journal of Geomorphology, v. 1, no. 4, p. 296-323.

Smith, J.F., and Ketner, K.B., 1972, Geologic map of the Carlin, Dixie Flats, Pine Valley, and Robinson Mountain Quadrangles, Elko and Eureka Counties, Nevada: U.S. Geological Survey Miscellaneous Field Studies Map MF-481.

Smith, J.L., Laczniak, R.J., Moreo, M.T., and Welborn, T.L., 2007, Mapping evapotranspiration units in the Basin and Range carbonate-rock aquifer system, White Pine County, Nevada, and adjacent areas in Nevada and Utah: U.S. Geological Survey Scientific Investigations Report 2007-5087, 20 p., accessed August 2, 2010, at http://pubs.usgs.gov/ sir/2007/5087/

Thomasson, H.G., Jr., Olmsted, F.H., and LeRoux, E.F., 1960, Geology, water resources, and usable ground-water storage capacity of part of Solano County, California: U.S. Geological Survey Water-Supply Paper 1464, 693 p.

U.S. Geological Survey EROS Data Center, 2006, Greenness of the conterminous U.S.: U.S. Geological Survey data available on the Web, accessed May 4, 2007, at http://ivm. cr.usgs.gov/.

Wallace, A.R., Perkins, M.E., and Fleck, R.J, 2008, Late Cenozoic paleogeographic evolution of northeastern NevadaEvidence from the sedimentary basins: Geosphere, v. 4, no. 1, p. 36-74.

Welch, A.H., Bright, D.J., and Knochenmus, L.A., 2007, Water resources of the basin and range carbonate-rock aquifer system, White Pine County, Nevada, and adjacent areas in Nevada and Utah: U.S. Geological Survey Scientific Investigations Report 2007-5261, 96 p. 


\section{Appendixes}

Appendix 1. Sites where streamflow was measured, October 2008 and November 2009, upper Humboldt River basin, northeastern Nevada.

[See figure 12 for site locations. Abbreviations: $\mathrm{ft}^{3} / \mathrm{s}$, cubic feet per second; USGS, U.S. Geological Survey]

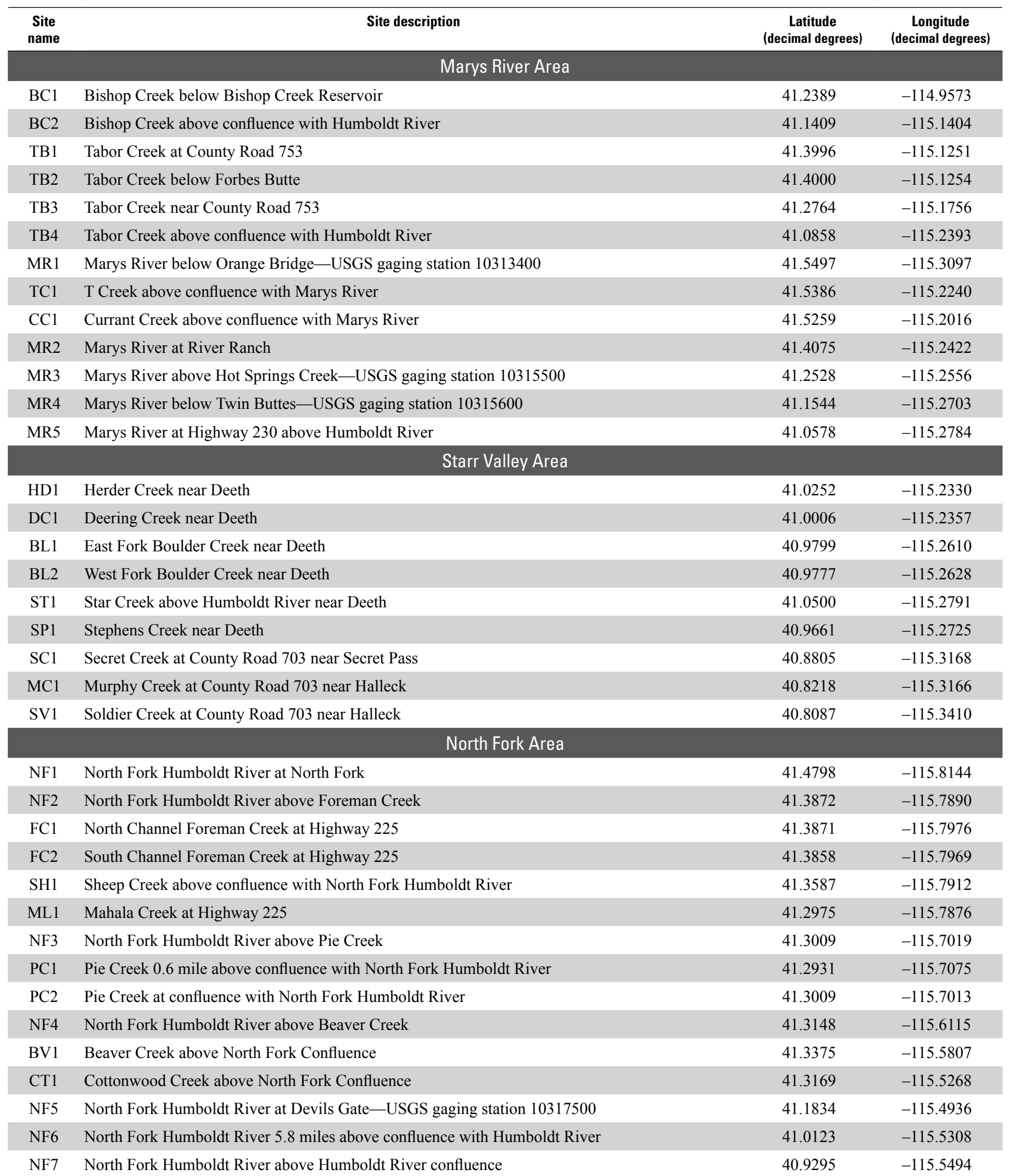


Appendix 1. Sites where streamflow was measured, October 2008 and November 2009, upper Humboldt River basin, northeastern Nevada.-Continued

[See figure 12 for site locations. Abbreviations: $\mathrm{ft}^{3} / \mathrm{s}$, cubic feet per second; USGS, U.S. Geological Survey]

\begin{tabular}{|c|c|c|c|}
\hline $\begin{array}{l}\text { Site } \\
\text { name }\end{array}$ & Site description & $\begin{array}{c}\text { Latitude } \\
\text { (decimal degrees) }\end{array}$ & $\begin{array}{c}\text { Longitude } \\
\text { (decimal degrees) }\end{array}$ \\
\hline \multicolumn{4}{|c|}{ Lamoille Valley } \\
\hline $\mathrm{LC} 1$ & Lamoille Creek near Lamoille_-USGS gaging station 10316500 & 40.6907 & -115.4770 \\
\hline $\mathrm{LC} 2$ & West Channel Lamoille Creek at Lamoille & 40.7274 & -115.4811 \\
\hline LC3 & East Channel Lamoille Creek at Lamoille & 40.7277 & -115.4791 \\
\hline $\mathrm{LC} 4$ & West Channel Lamoille Creek at Lower Lamoille Road & 40.7658 & -115.4783 \\
\hline LC5 & East Channel Lamoille Creek at Lower Lamoille Road & 40.7659 & -115.4714 \\
\hline LC6 & Lamoille Creek diversion at Lower Lamoille Road & 40.7659 & -115.4763 \\
\hline $\mathrm{LC} 7$ & Lamoille Creek diversion at Lower Lamoille Road & 40.7659 & -115.4698 \\
\hline JD1 & John Day Creek at County Road 703 & 40.8044 & -115.3767 \\
\hline CL1 & Cold Creek at Lower Lamoille Road & 40.8050 & -115.3789 \\
\hline TH1 & Thorpe Creek at County Road 704 & 40.7549 & -115.4381 \\
\hline TL1 & Talbot Creek at County Road 704 & 40.7385 & -115.4467 \\
\hline TL2 & Talbot Creek at Lower Lamoille Road & 40.7663 & -115.4601 \\
\hline LC8 & Lamoille Creek above Humboldt River near Halleck & 40.9315 & -115.4627 \\
\hline \multicolumn{4}{|c|}{ Huntington Valley } \\
\hline $\mathrm{HC} 1$ & Huntington Creek below Defue Spring & 40.0266 & -115.7473 \\
\hline $\mathrm{HC} 2$ & Huntington Creek near Railroad Pass & 40.1163 & -115.7684 \\
\hline $\mathrm{HC} 3$ & Huntington Creek near Homestead Spring & 40.2031 & -115.7539 \\
\hline $\mathrm{HC} 4$ & Huntington Creek near Jiggs & 40.4213 & -115.7071 \\
\hline SM1 & South Fork Smith Creek near Jiggs & 40.4222 & -115.6673 \\
\hline SM2 & North Fork Smith Creek near Jiggs & 40.4232 & -115.6667 \\
\hline SM3 & Smith Creek at Jiggs & 40.4284 & -115.6657 \\
\hline HC5 & Huntington Creek above Cottonwood Creek confluence & 40.5043 & -115.7289 \\
\hline CW1 & Cottonwood Creek near Jiggs & 40.4856 & -115.6631 \\
\hline HC6 & Huntington Creek above Willow Creek confluence & 40.5364 & -115.7229 \\
\hline WC1 & Willow Creek at Highway 228 near Jiggs & 40.5197 & -115.6634 \\
\hline $\mathrm{HC7}$ & Huntington Creek below Willow Creek confluence & 40.5629 & -115.7188 \\
\hline $\mathrm{HC} 8$ & Huntington Creek above confluence with South Fork Humboldt River & 40.6179 & -115.7292 \\
\hline \multicolumn{4}{|c|}{ South Fork Area } \\
\hline SF1 & South Fork Humboldt River at Lee & 40.5643 & -115.6068 \\
\hline SF2 & South Fork Humboldt River at Highway 228 & 40.6057 & -115.6914 \\
\hline SF3 & South Fork Humboldt River above confluence with Huntington Creek & 40.6224 & -115.7266 \\
\hline \multicolumn{4}{|c|}{ Dixie Creek-Tenmile Creek Area } \\
\hline SF4 & South Fork Humboldt River above Tenmile Creek-USGS gaging station 10319900 & 40.6274 & -115.7307 \\
\hline MT1 & Mitchell Creek near Spring Creek & 40.6959 & -115.6238 \\
\hline UN1 & Unnamed Creek near Spring Creek & 40.7026 & -115.6238 \\
\hline $\mathrm{BF} 1$ & Butterfield Creek near Spring Creek & 40.7064 & -115.6239 \\
\hline DR1 & Dry Creek near Spring Creek & 40.7198 & -115.6241 \\
\hline TM1 & Tenmile Creek near Spring Creek & 40.7240 & -115.6234 \\
\hline TM2 & Tenmile Creek tributary near Spring Creek & 40.7357 & -115.6241 \\
\hline SP1 & Spring Creek near Spring Creek & 40.7531 & -115.6304 \\
\hline TM3 & Tenmile Creek at Highway 228 & 40.7356 & -115.7010 \\
\hline TM4 & Tenmile Creek near South Fork Reservoir & 40.7042 & -115.7534 \\
\hline TM5 & Tenmile Creek above South Fork Humboldt River confluence & 40.6872 & -115.7920 \\
\hline
\end{tabular}


Appendix 1. Sites where streamflow was measured, October 2008 and November 2009, upper Humboldt River basin, northeastern Nevada.-Continued

[See figure 12 for site locations. Abbreviations: $\mathrm{ft}^{3} / \mathrm{s}$, cubic feet per second; USGS, U.S. Geological Survey]

\begin{tabular}{|c|c|c|c|}
\hline $\begin{array}{c}\text { Site } \\
\text { name }\end{array}$ & Site description & $\begin{array}{c}\text { Latitude } \\
\text { (decimal degrees) }\end{array}$ & $\begin{array}{c}\text { Longitude } \\
\text { (decimal degrees) }\end{array}$ \\
\hline \multicolumn{4}{|c|}{ Dixie Creek-Tenmile Creek Area—Continued } \\
\hline SF5 & South Fork Humboldt River above Dixie Creek_-USGS gaging station 10320000 & 40.6849 & -115.8139 \\
\hline SF6 & South Fork Humboldt River above confluence with Dixie Creek & 40.6844 & -115.8409 \\
\hline DX1 & Dixie Creek at Dixie Creek Flat & 40.6294 & -115.8627 \\
\hline DX2 & Dixie Creek below Dixie Creek Flat & 40.6592 & -115.8547 \\
\hline DX3 & Dixie Creek above confluence with South Fork Humboldt River & 40.6826 & -115.8443 \\
\hline SF7 & South Fork Humboldt River near Dixie Creek & 40.6978 & -115.8349 \\
\hline SF8 & South Fork Humboldt River below Bullion Road & 40.7233 & -115.8306 \\
\hline SF9 & South Fork Humboldt River near spring & 40.7444 & -115.8479 \\
\hline SF10 & South Fork Humboldt River below spring & 40.7462 & -115.8525 \\
\hline SF11 & South Fork Humboldt River at mouth of South Fork Canyon & 40.7460 & -115.8601 \\
\hline SF12 & South Fork Humboldt River above Humboldt River confluence & 40.7721 & -115.8877 \\
\hline \multicolumn{4}{|c|}{ Mainstem Humboldt River } \\
\hline HR1 & Humboldt River above Bishop Creek confluence & 41.1417 & -115.1111 \\
\hline HR2 & Humboldt River below Trout Creek & 41.1400 & -115.1402 \\
\hline HR3 & Humboldt River at Highway 230 & 41.0551 & -115.2758 \\
\hline HR4 & Center Channel Humboldt River near Deeth & 40.9971 & -115.4102 \\
\hline HR5 & Right Channel Humboldt River near Deeth & 40.9926 & -115.4219 \\
\hline HR6 & Right Channel Humboldt River near Halleck & 40.9508 & -115.4473 \\
\hline HR7 & Center Channel Humboldt River near Halleck & 40.9497 & -115.4437 \\
\hline HR8 & Humboldt River above Lamoille Creek & 40.9311 & -115.4716 \\
\hline HR9 & Humboldt River at Elburz & 40.9262 & -115.5112 \\
\hline HR10 & Humboldt River near Elko-_USGS gaging station 10318500 & 40.9337 & -115.6259 \\
\hline HR11 & Humboldt River at Last Chance Road near Elko & 40.8774 & -115.7006 \\
\hline HR12 & Humboldt River at 12th Street Bridge in Elko & 40.8339 & -115.7503 \\
\hline HR13 & Humboldt River at Elko sewage disposal plant & 40.8182 & -115.7886 \\
\hline HR14 & Humboldt River at Miller Ranch & 40.8073 & -115.8123 \\
\hline HR15 & Humboldt River above South Fork Humboldt River confluence & 40.7716 & -115.8857 \\
\hline HR16 & Humboldt River near Carlin-USGS gaging station 10321000 & 40.7273 & -116.0095 \\
\hline
\end{tabular}


Appendix 2. Streamflow on the Humboldt River and its tributaries, October 20-24, 2008, upper Humboldt River basin, northeastern Nevada.

[See figures 12-18 and appendix 1. Abbreviations: $\mathrm{ft}^{3} / \mathrm{s}$, cubic feet per second]

\section{Marys River (fig. 13a-b)}

\begin{tabular}{cc}
\hline Site name & Discharge $\left(\mathbf{f t}^{\mathbf{3}} \mathbf{/} \mathbf{s}\right)$ \\
\hline MR1 & 2.53 \\
MR2 & 0.00 \\
MR3 & 2.00 \\
MR4 & 0.00 \\
MR5 & 0.00
\end{tabular}

North Fork Humboldt River and its tributaries (fig. 14a-b)

\begin{tabular}{|c|c|c|c|c|c|c|c|}
\hline \multirow{2}{*}{ Site name } & \multicolumn{7}{|c|}{ Discharge $\left(\mathrm{ft}^{3} / \mathrm{s}\right)$} \\
\hline & North Fork & Foreman Creek & Sheep Creek & Mahala Creek & Pie Creek & Beaver Creek & Cottonwood Creek \\
\hline NF1 & 2.18 & & & & & & \\
\hline NF2 & 1.99 & & & & & & \\
\hline $\mathrm{FC} 1$ & & 0.00 & & & & & \\
\hline $\mathrm{FC} 2$ & & 0.00 & & & & & \\
\hline SH1 & & & 0.00 & & & & \\
\hline NF3 & 1.07 & & & & & & \\
\hline $\mathrm{PC} 2$ & & & & & 6.01 & & \\
\hline NF4 & 5.85 & & & & & & \\
\hline BV1 & & & & & & 0.69 & \\
\hline CT1 & & & & & & & 0.00 \\
\hline
\end{tabular}

Lamoille Creek (fig. 15a-b)

\begin{tabular}{|cc}
\hline Site name & Discharge (ft $\mathbf{3} / \mathbf{s})$ \\
\hline LC1 & 4.27 \\
\hline LC2 & 1.05 \\
LC3 & 0.64 \\
LC4 & 0.54 \\
LC5 & 0.00 \\
\hline LC6 & 0.00 \\
LC7 & 0.12 \\
\hline LC8 & 0.13 \\
\hline
\end{tabular}

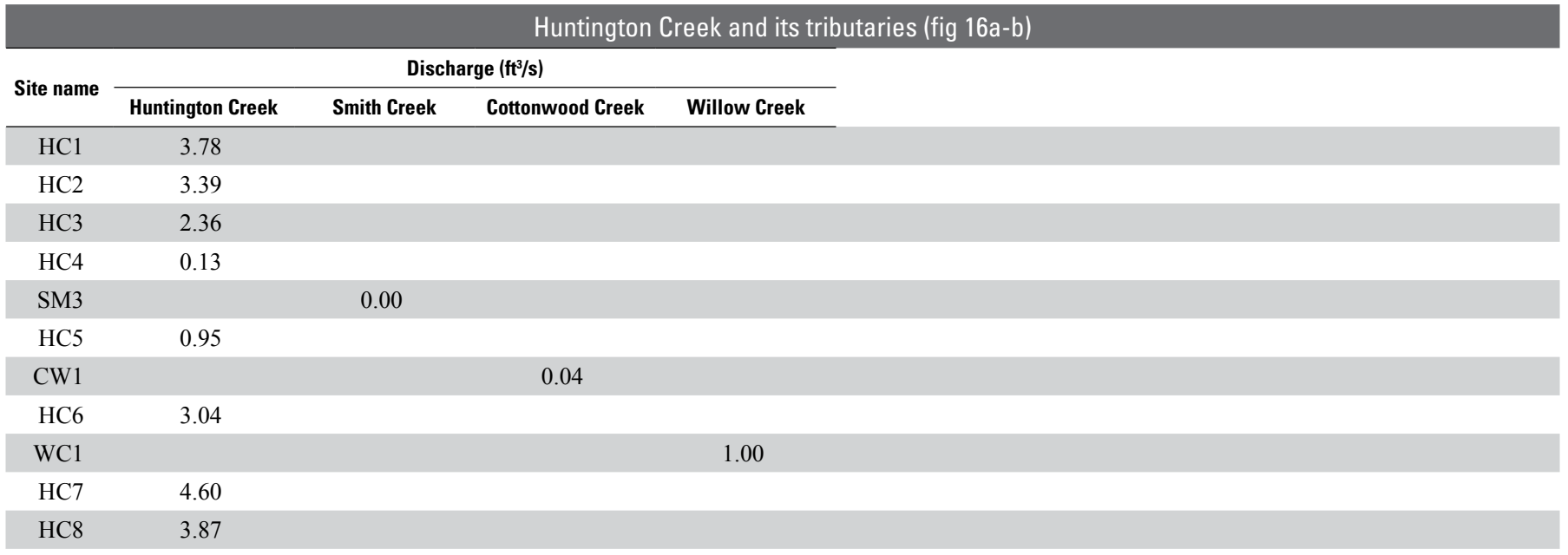


Appendix 2. Streamflow on the Humboldt River and its tributaries, October 20-24, 2008, upper Humboldt River basin, northeastern Nevada.-Continued

[See figures $12-18$ and appendix 1. Abbreviations: $\mathrm{ft}^{3} / \mathrm{s}$, cubic feet per second]

South Fork Humboldt River and its tributaries (fig. 17a-b)

\begin{tabular}{|c|c|c|c|c|}
\hline \multirow{2}{*}{ Site name } & \multicolumn{4}{|c|}{ Discharge (ft $\mathbf{3} / \mathbf{s})$} \\
\hline & South Fork & Huntington Creek & Tenmile Creek & Dixie Creek \\
\hline SF2 & 1.66 & & & \\
\hline SF3 & 0.74 & & & \\
\hline $\mathrm{HC} 8$ & & 3.87 & & \\
\hline SF4 & 7.58 & & & \\
\hline TM5 & & & 2.27 & \\
\hline SF5 & 4.23 & & & \\
\hline SF6 & 4.51 & & & \\
\hline DX3 & & & & 0.00 \\
\hline SF8 & 2.24 & & & \\
\hline SF11 & 16.97 & & & \\
\hline SF12 & 15.00 & & & \\
\hline
\end{tabular}

Humboldt River and its tributaries

\begin{tabular}{|c|c|c|c|c|c|c|c|c|}
\hline \multirow{2}{*}{ Site name } & \multicolumn{8}{|c|}{ Discharge $\left(\mathrm{ft}^{3} / \mathrm{s}\right)$} \\
\hline & Bishop Creek & Humboldt River & Tabor Creek & Marys River & Starr Creek & Lamoille Creek & North Fork & South Fork \\
\hline $\mathrm{BC} 2$ & 3.56 & & & & & & & \\
\hline HR2 & & 3.39 & & & & & & \\
\hline TB4 & & & 0 & & & & & \\
\hline HR3 & & 0.00 & & & & & & \\
\hline MR5 & & & & 0 & & & & \\
\hline HR6\&7 & & 0.00 & & & & & & \\
\hline HR8 & & 0.00 & & & & & & \\
\hline LC8 & & & & & & 0.13 & & \\
\hline HR9 & & 0.36 & & & & & & \\
\hline HR13 & & 1.90 & & & & & & \\
\hline HR14 & & 1.60 & & & & & & \\
\hline HR15 & & 1.54 & & & & & & \\
\hline SF12 & & & & & & & & 15 \\
\hline HR16 & & 18.14 & & & & & & \\
\hline
\end{tabular}


Appendix 3. Streamflow on the Humboldt River and its tributaries, November 2-6, 2009, upper Humboldt River basin, northeastern Nevada.

[See figures 12-18 and appendix 1. Abbreviations: $\mathrm{ft}^{3} / \mathrm{s}$, cubic feet per second]

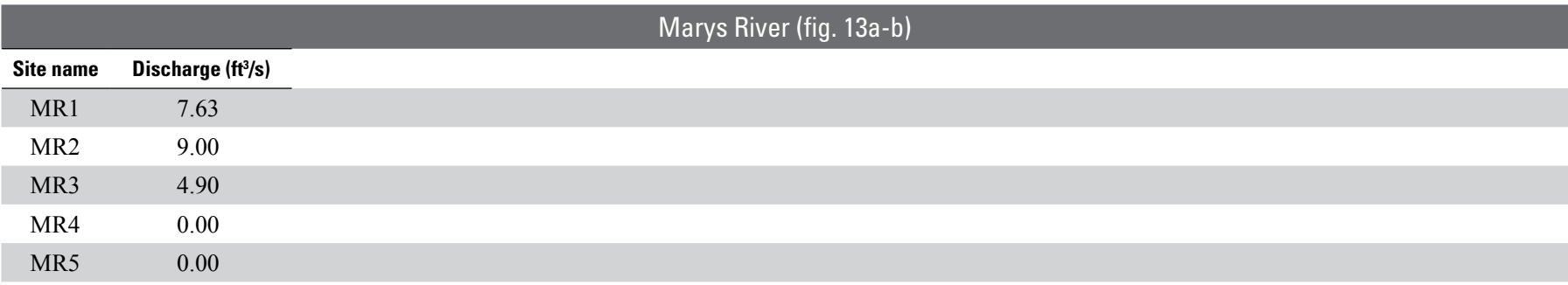

\begin{tabular}{|c|c|c|c|c|c|c|c|}
\hline \multirow{2}{*}{ Site name } & \multicolumn{7}{|c|}{ Discharge $\left(\mathrm{ft}^{3} / \mathrm{s}\right)$} \\
\hline & North Fork & Foreman Creek & Sheep Creek & Mahala Creek & Pie Creek & Beaver Creek & Cottonwood Creek \\
\hline NF1 & 4.81 & & & & & & \\
\hline NF2 & 5.85 & & & & & & \\
\hline $\mathrm{FC} 1$ & & 0.00 & & & & & \\
\hline $\mathrm{FC} 2$ & & 0.00 & & & & & \\
\hline SH1 & & & 0.00 & & & & \\
\hline ML1 & & & & 0.00 & & & \\
\hline NF3 & 5.82 & & & & & & \\
\hline $\mathrm{PC} 1$ & & & & & 6.31 & & \\
\hline $\mathrm{PC} 2$ & & & & & 12.60 & & \\
\hline NF4 & 12.70 & & & & & & \\
\hline BV1 & & & & & & 1.73 & \\
\hline CT1 & & & & & & & 0.00 \\
\hline NF5 & 18.80 & & & & & & \\
\hline NF6 & 15.60 & & & & & & \\
\hline NF7 & 12.69 & & & & & & \\
\hline Site name & Discharge $\left(\mathrm{ft}^{3} / \mathrm{s}\right)$ & & & & & & \\
\hline LC1 & 4.88 & & & & & & \\
\hline $\mathrm{LC} 2$ & 0.71 & & & & & & \\
\hline LC3 & 2.07 & & & & & & \\
\hline $\mathrm{LC} 4$ & 0.65 & & & & & & \\
\hline $\mathrm{LC} 5$ & 0.00 & & & & & & \\
\hline LC6 & 0.78 & & & & & & \\
\hline $\mathrm{LC} 7$ & 0.00 & & & & & & \\
\hline LC8 & 0.41 & & & & & & \\
\hline
\end{tabular}

Huntington Creek and its tributaries (fig 16a-b)

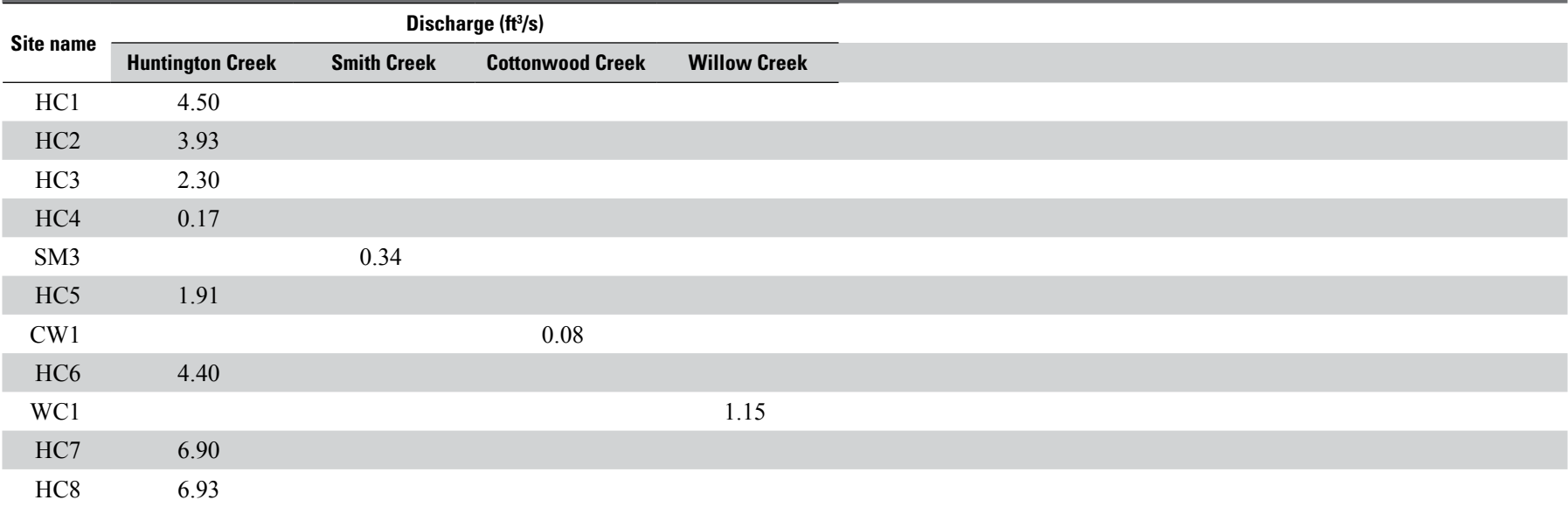


Appendix 3. Streamflow on the Humboldt River and its tributaries, November 2-6, 2009, upper Humboldt River basin, northeastern Nevada.-Continued

[See figures 12-18 and appendix 1. Abbreviations: $\mathrm{ft}^{\mathrm{t}} / \mathrm{s}$, cubic feet per second]

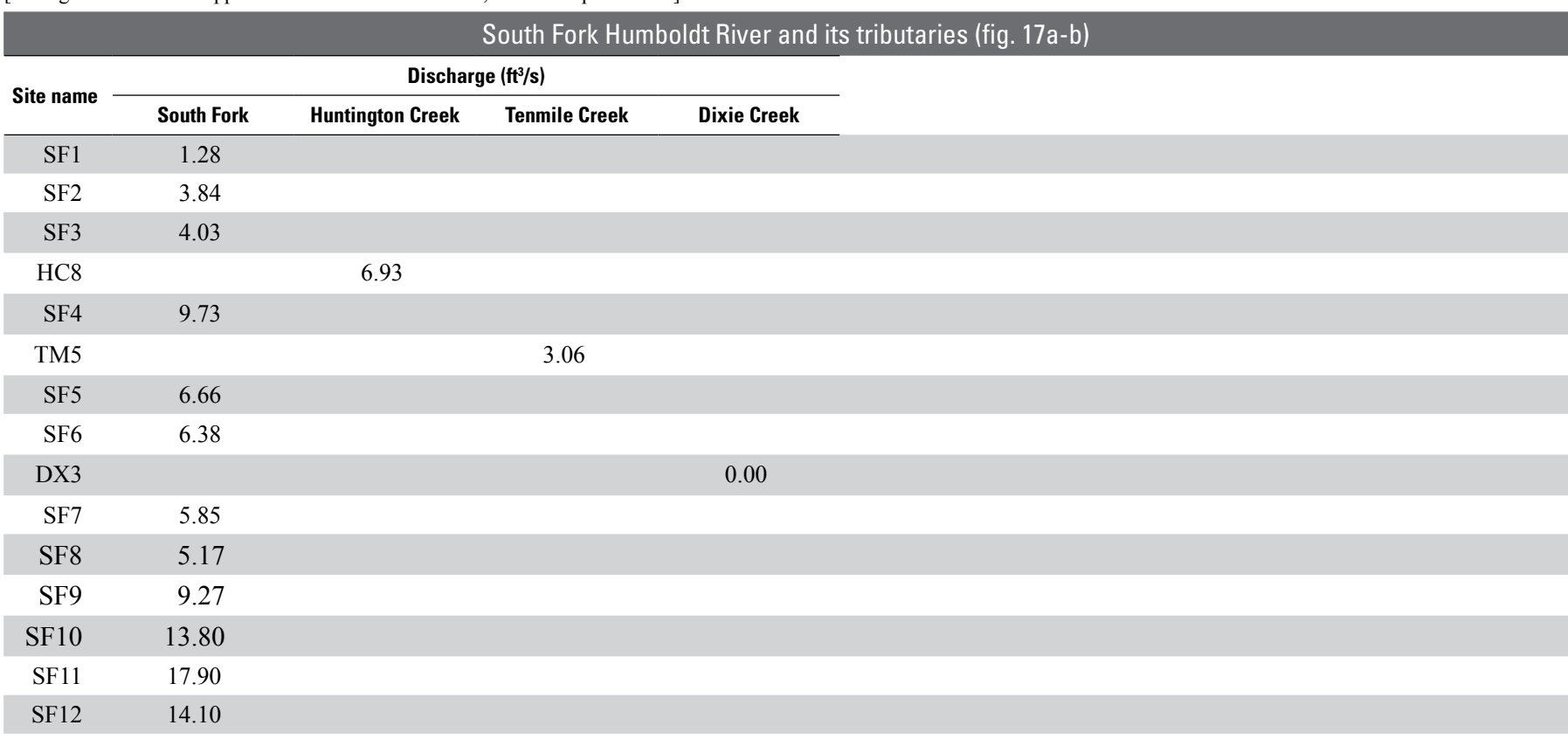

Humboldt River and its tributaries

\begin{tabular}{|c|c|c|c|c|c|c|c|c|}
\hline \multirow{2}{*}{ Site name } & \multicolumn{8}{|c|}{ Discharge $\left(\mathrm{ft}^{3} / \mathbf{s}\right)$} \\
\hline & Bishop Creek & Humboldt River & Tabor Creek & Marys River & Starr Creek & Lamoille Creek & North Fork & South Fork \\
\hline HR1 & 0.48 & & & & & & & \\
\hline TB4 & & & 0.00 & & & & & \\
\hline HR3 & 0.00 & & & & & & & \\
\hline MR5 & & & & 0.00 & & & & \\
\hline HR4\&5 & 0.00 & & & & & & & \\
\hline HR6\&7 & 0.31 & & & & & & & \\
\hline HR8 & 0.00 & & & & & & & \\
\hline LC8 & & & & & & 0.41 & & \\
\hline HR9 & 1.03 & & & & & & & \\
\hline HR12 & 12.40 & & & & & & & \\
\hline HR13 & 13.50 & & & & & & & \\
\hline HR14 & 14.60 & & & & & & & \\
\hline HR15 & 14.10 & & & & & & & \\
\hline SF12 & & & & & & & & 14.10 \\
\hline HR16 & 33.20 & & & & & & & \\
\hline
\end{tabular}





\section{总}

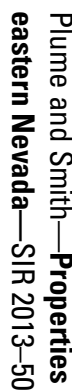
거음 